ats

EGG- -2213

EGG-2213

DE83 000653

Distribution Category: UC-66d

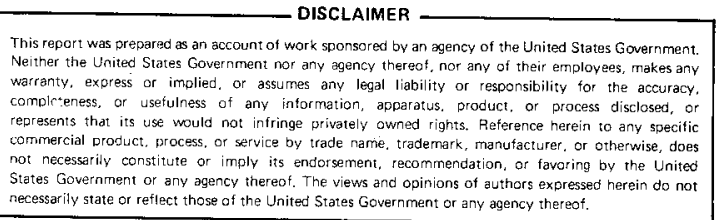

\title{
AN EVALUATION OF MATERIALS FOR SYSTEMS USING COOLED, TREATED GEOTHERMAL OR HIGH-SALINE BRINES
}

\author{
Dan .F. Suciu \\ Penny. M. Wikoff

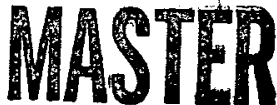

Published September 1982

EG\&G Idaho, Inc. Idaho Falls, Idaho 83415

Prepared for the

U.S. Department of Energy

Idaho Operations Office

Under DOE Contract No. DE-AC07-76ID01570 


\section{DISCLAIMER}

This report was prepared as an account of work sponsored by an agency of the United States Government. Neither the United States Government nor any agency Thereof, nor any of their employees, makes any warranty, express or implied, or assumes any legal liability or responsibility for the accuracy, completeness, or usefulness of any information, apparatus, product, or process disclosed, or represents that its use would not infringe privately owned rights. Reference herein to any specific commercial product, process, or service by trade name, trademark, manufacturer, or otherwise does not necessarily constitute or imply its endorsement, recommendation, or favoring by the United States Government or any agency thereof. The views and opinions of authors expressed herein do not necessarily state or reflect those of the United States Government or any agency thereof. 


\section{DISCLAIMER}

Portions of this document may be illegible in electronic image products. Images are produced from the best available original document. 


\begin{abstract}
Lack of adequate quantities of clean surface water for use in wet (evaporative) cooling systems indicates the use of high-salinity waste waters, or cooled geothermal brines, for makeup purposes. Highchloride, aerated water represents an extremely corrosive environment. In order to determine metals suitable for use in such an environment, metal coupons were exposed to aerated, treated geothermal brine salted to a chloride concentration of 10,000 and $50,000 \mathrm{ppm}(\mathrm{mg} / \mathrm{L})$ for periods of up to 30 days. The exposed coupons were evaluated to determine the general, pitting, and crevice corrosion characteristics of the metals. The metals exhibiting corrosion resistance at $50,000 \mathrm{ppm}$ chloride were then evaluated at 100,000 and $200,000 \mathrm{ppm}$ chloride. Since these were screening tests to select materials for components to be used in a cooling system, with primary emphasis on condenser tubing, several materials were exposed for 4 to 10 months in pilot

cooling tower test units with heat transfer for further corrosion evaluation.

The results of the screening tests indicate that ferritic stainless steels (29-4-2 and SEA-CURE) exhibit excellent corrosion resistance at all levels of chloride concentration. Copper-nickel alloys (70/30 and Monel 400) exhibited excellent corrosion resistance in the high-saline water. The $70 / 30$ copper-nickel alloy, which showed excellent resistance to general corrosion, exhibited mild pitting in the 30-day tests. This pitting was not apparent, however, after 6 months of exposure in the pilot cooling tower tests. The nickel-base alloys exhibited excellent corrosion resistance, but their high cost prevents their use unless no other material is found feasible. Other materials tested, although unsuitable for condenser tubing material, would be suitable as tube sheet material.
\end{abstract}




\section{CONTENTS}

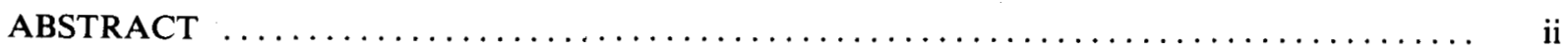

1. INTRODUCTION AND SUMMARY $\ldots \ldots \ldots \ldots \ldots \ldots \ldots \ldots \ldots \ldots \ldots \ldots \ldots \ldots \ldots \ldots \ldots$

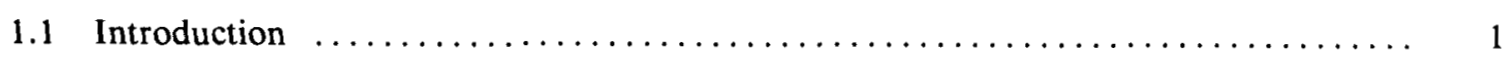

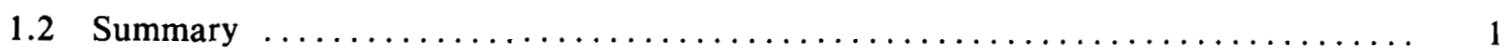

2. TEST EQUIPMENT AND PROCEDURES $\ldots \ldots \ldots \ldots \ldots \ldots \ldots \ldots \ldots \ldots \ldots \ldots \ldots \ldots \ldots$

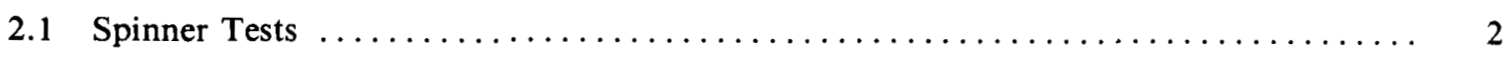

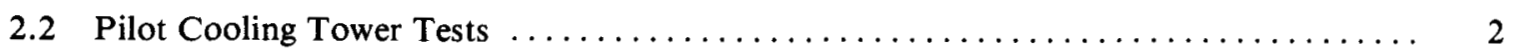

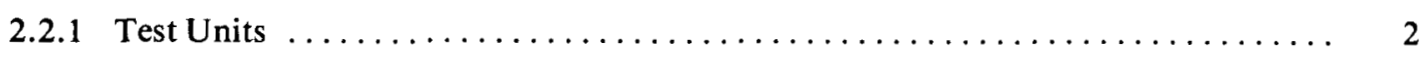

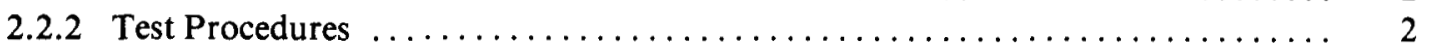

3. TEST RESULTS AND DISCUSSION $\ldots \ldots \ldots \ldots \ldots \ldots \ldots \ldots \ldots \ldots \ldots \ldots \ldots \ldots \ldots$

3.1 Corrosion Tests at $10,000 \mathrm{ppm}$ Chloride $\ldots \ldots \ldots \ldots \ldots \ldots \ldots \ldots \ldots \ldots \ldots \ldots \ldots$

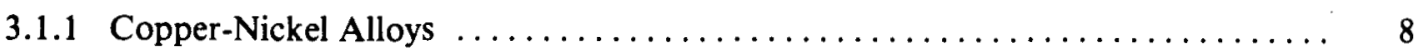

3.1.2 Copper-Zinc Alloys $\ldots \ldots \ldots \ldots \ldots \ldots \ldots \ldots \ldots \ldots \ldots \ldots \ldots \ldots \ldots \ldots \ldots \ldots \ldots, \quad 8$

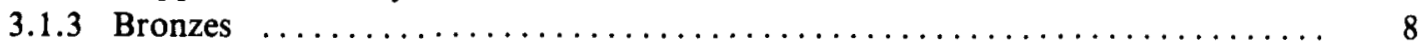

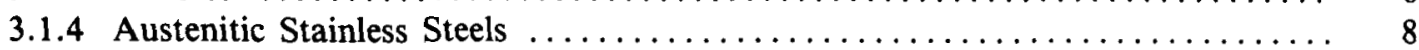

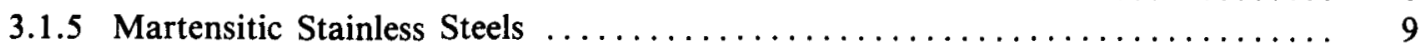

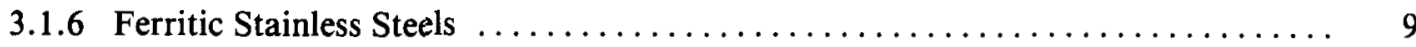

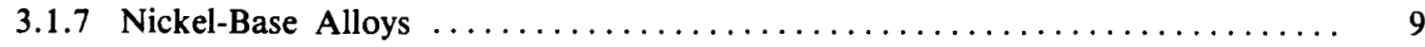

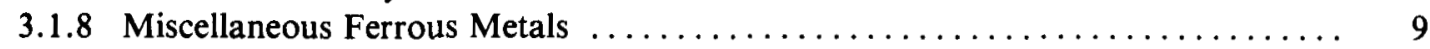

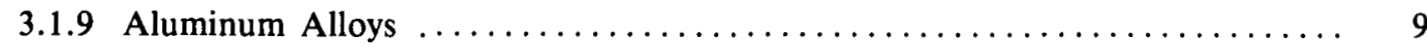

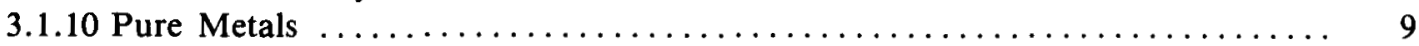

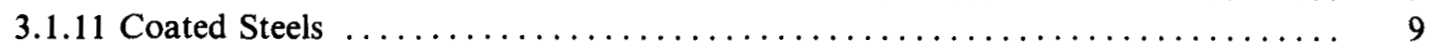

3.2 Corrosion Tests at $50,000 \mathrm{ppm}$ Chloride $\ldots \ldots \ldots \ldots \ldots \ldots \ldots \ldots \ldots \ldots \ldots \ldots \ldots \ldots$

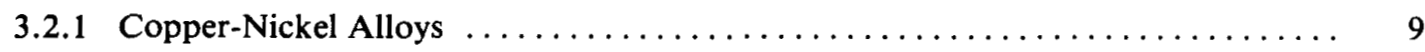

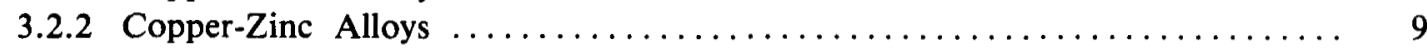

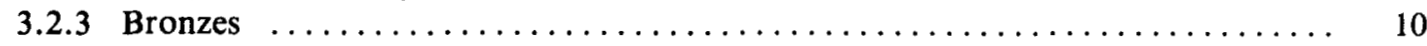

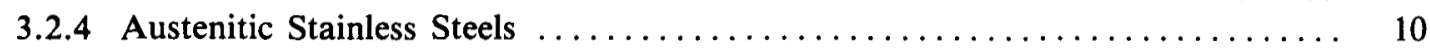

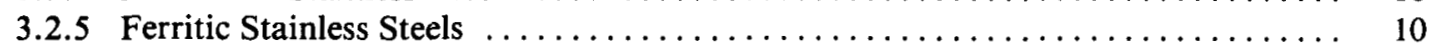

3.2.6 Pure Metals $\ldots \ldots \ldots \ldots \ldots \ldots \ldots \ldots \ldots \ldots \ldots \ldots \ldots \ldots \ldots, 10$

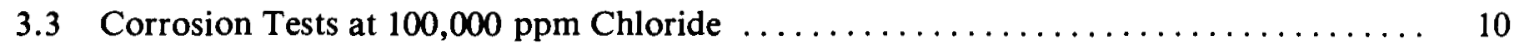

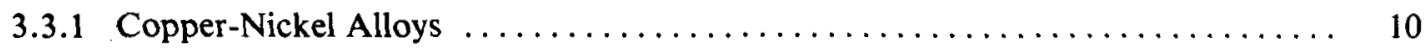

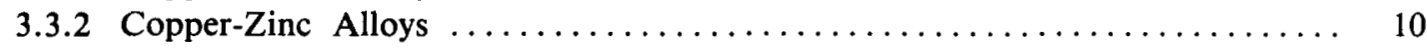

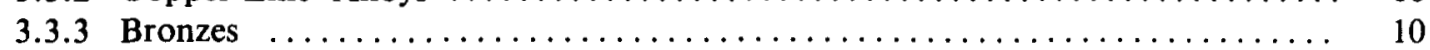

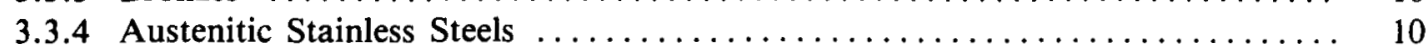

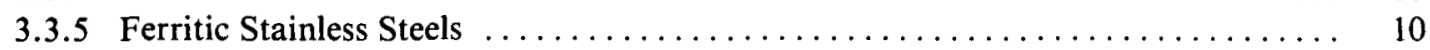

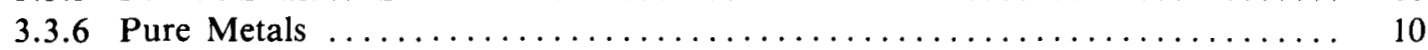


3.4 Corrosion Tests at $200,000 \mathrm{ppm}$ Chloride $\ldots \ldots \ldots \ldots \ldots \ldots \ldots \ldots \ldots \ldots \ldots \ldots \ldots \ldots \ldots$

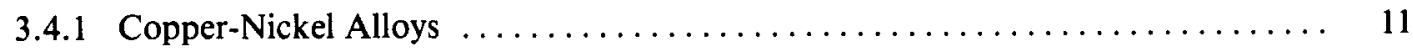

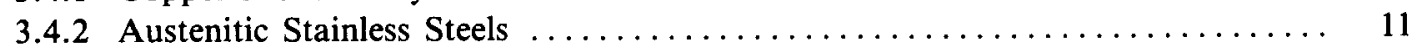

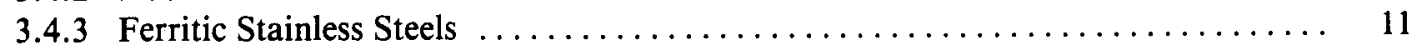

3.4.4 Pure Metals $\ldots \ldots \ldots \ldots \ldots \ldots \ldots \ldots \ldots \ldots \ldots \ldots \ldots \ldots \ldots \ldots \ldots \ldots, 11$

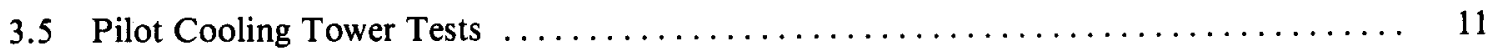

4. CONCLUSIONS AND RECOMMENDATIONS $\ldots \ldots \ldots \ldots \ldots \ldots \ldots \ldots \ldots \ldots \ldots \ldots$

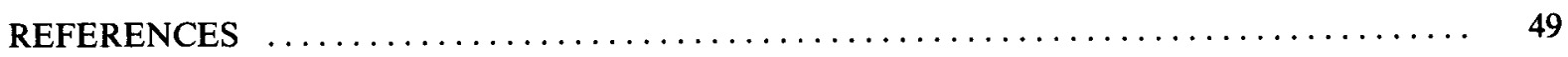

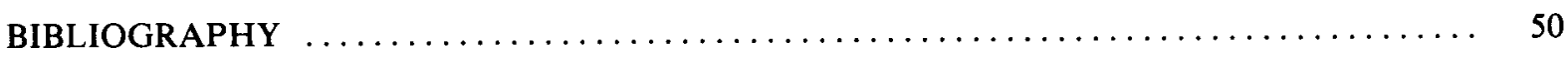

\section{FIGURES}

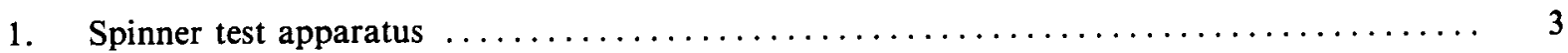

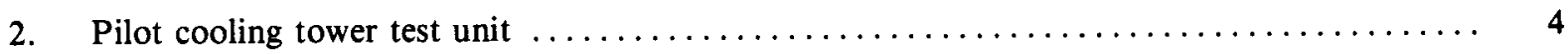

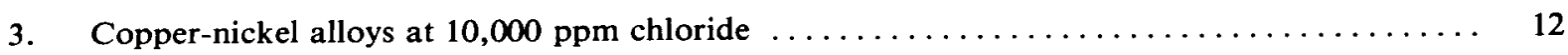

4. Copper-zinc alloys at $10,000 \mathrm{ppm}$ chloride $\ldots \ldots \ldots \ldots \ldots \ldots \ldots \ldots \ldots \ldots \ldots \ldots \ldots \ldots \ldots \ldots \ldots \ldots \ldots$

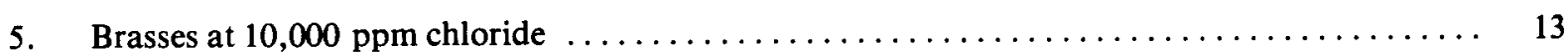

6. High-silicon bronze and aluminum bronze at $10,000 \mathrm{ppm}$ chloride $\ldots \ldots \ldots \ldots \ldots \ldots \ldots$

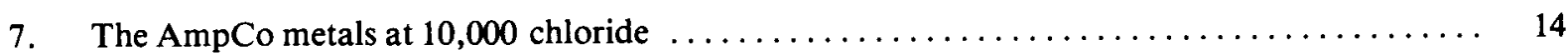

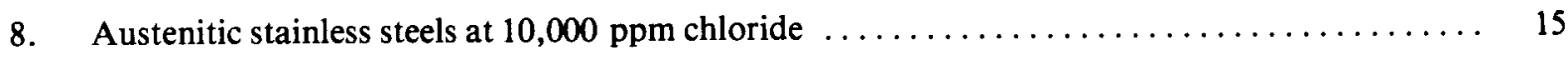

9. Martensitic stainless steels at 10,000 ppm chloride $\ldots \ldots \ldots \ldots \ldots \ldots \ldots \ldots \ldots \ldots \ldots \ldots \ldots \ldots \ldots \ldots \ldots$

10. Ferritic stainless steels at 10,000 ppm chloride $\ldots \ldots \ldots \ldots \ldots \ldots \ldots \ldots \ldots \ldots \ldots \ldots \ldots \ldots \ldots \ldots \ldots$

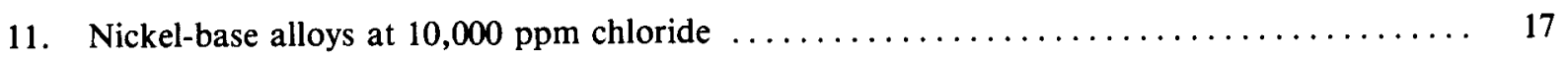

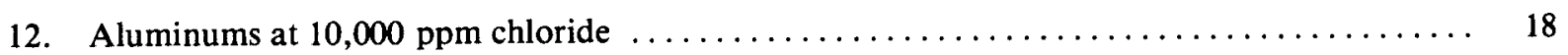

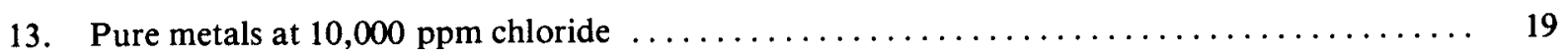

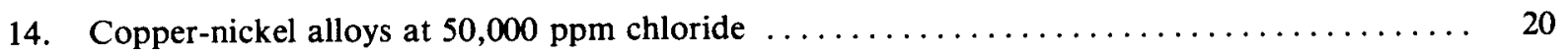

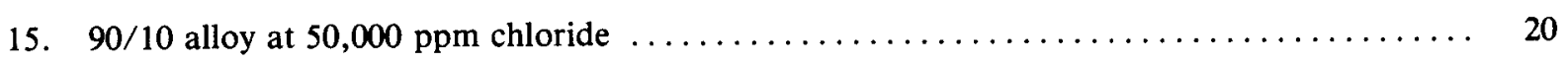

16. Copper-zinc alloys at $50,000 \mathrm{ppm}$ chloride $\ldots \ldots \ldots \ldots \ldots \ldots \ldots \ldots \ldots \ldots \ldots \ldots \ldots \ldots \ldots \ldots \ldots \ldots \ldots$

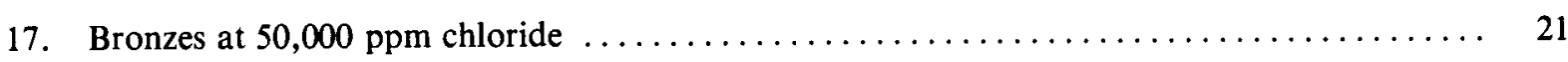

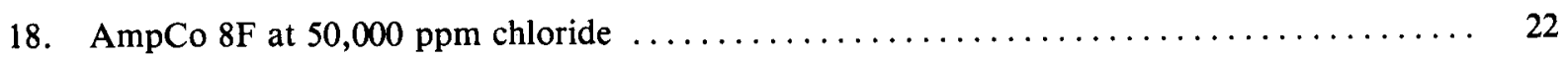

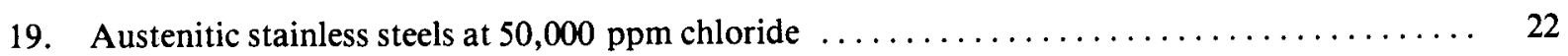


20. Ferritic stainless steels at 50,000 ppm chloride

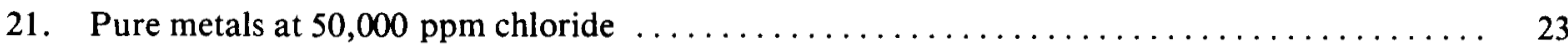

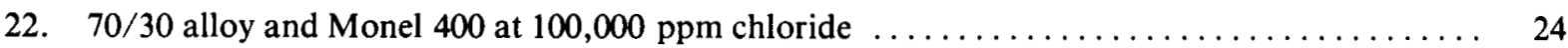

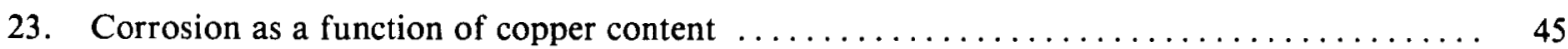

24. Corrosion as a function of chloride concentration level $\ldots \ldots \ldots \ldots \ldots \ldots \ldots \ldots \ldots \ldots, 46$

25. Corrosion as a function of chloride concentration level $\ldots \ldots \ldots \ldots \ldots \ldots \ldots \ldots \ldots .47$

\section{TABLES}

1. Typical water analysis of solutions used for spinner tests $\ldots \ldots \ldots \ldots \ldots \ldots \ldots \ldots \ldots$

2. Typical analysis of circulating water in the pilot cooling tower corrosion tests $\ldots \ldots \ldots \ldots \ldots$

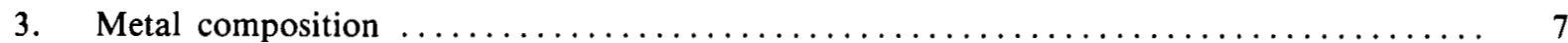

4. Corrosion of metals after corrosion testing for 1 month in the spinner tests $\ldots \ldots \ldots \ldots \ldots$. 25

5. General corrosion of metals with time during corrosion testing in the spinner

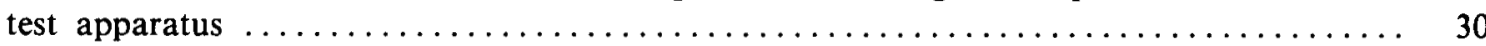

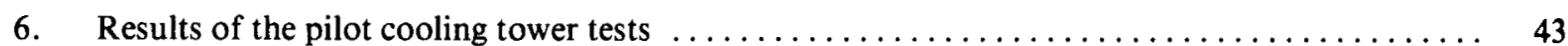

7. Dissolved oxygen as a function of chloride concentration $\ldots \ldots \ldots \ldots \ldots \ldots \ldots \ldots \ldots \ldots \ldots$

8. Comparison of corrosion rates of materials exposed to geothermal brine and to seawater $\ldots \ldots \quad 48$ 


\section{AN EVALUATION OF MATERIALS FOR SYSTEMS USING COOLED, TREATED GEOTHERMAL OR HIGH-SALINE BRINES}

\section{INTRODUCTION AND SUMMARY}

\subsection{Introduction}

Increasing concern about the availability of water for domestic purposes will require that industrial water users use lower quality water for their applications. The largest industrial consumption of water occurs in power plant cooling systems. In general, the water for these uses will be high-saline water. High-saline, aerated water is an extremely corrosive environment that requires special concern in material selection. The purpose of this investigation was to determine the corrosion characteristics of a number of alloys that might be used in cooling system components.

Initially, the test program was aimed at selecting a replacement tube material for the Raft River 5 MW(e) Pilot Power Plant isobutane carbon steel condenser. Later, it was directed toward solving the generic problems associated with geothermal areas where available water has a high salt content. When it is used in evaporative cooling systems, this water is concentrated 2 to 10 times, thus producing chloride concentrations comparable to the conditions tested.

The testing generally consisted of two phases: the spinner tests used for screening many materials in a short time, and pilot cooling tower tests that were conducted for periods of 4 to 10 months. The screening tests were 30 -day corrosion tests in which the metal samples were exposed to a warm, aerated, saline environment at 10,000 and $50,000 \mathrm{ppm}$ $(\mathrm{mg} / \mathrm{L})^{\mathrm{a}}$ chloride. The metals exhibiting good corrosion resistance were then exposed at 100,000 and $200,000 \mathrm{ppm}$ chloride. The $200,000 \mathrm{ppm}$ chloride solution is near the saturation limit for sodium

a. $\mathrm{ppm}$ is $\mathrm{mg} / \mathrm{L}$ throughout this paper. chloride but is not an unusual concentration for a high-saline brine. Corrosion characteristics were determined from weight loss data and by microscopic examination for pit formation and crevice corrosion. Finally, the materials that showed good corrosion resistance and were of moderate cost were then exposed in a pilot cooling tower test unit for 4 to 10 months. Test equipment, procedures, and results are discussed in the subsequent sections of this report.

\subsection{Summary}

The use of aerated, treated geothermal or other high-chloride water in cooling systems such as the Raft River 5 MW(e) geothermal power plant or other plants presents special problems in material selection. The corrosion tests discussed here were initially conducted to determine a replacement tube material for the Raft River 5 MW(e) Pilot Power Plant isobutane carbon steel condenser. In addition, the investigation included a preliminary evaluation of alternative materials for other cooling water systems using high-saline, aerated water. The corrosion resistance of a number of metals was determined using different chloride concentrations at a constant temperature, $\mathrm{pH}$, and velocity. The metal coupons tested were examined for pitting, crevice corrosion, and general corrosion.

The corrosion test results show excellent corrosion resistance by the 29-4-2 and SEA-CURE ferritic stainless steels. Monel 400, 70/30 copper-nickel, and 29-4-C exhibited excellent resistance to general corrosion, but in the spinner tests they exhibited mild pitting. This pitting was not apparent with 70/30 after 6 months of testing in the pilot cooling tower tests. 


\section{TEST EQUIPMENT AND PROCEDURES}

\subsection{Spinner Tests}

The corrosion studies were a series of 30-day tests conducted to determine the corrosive effects of aerated, high-chloride water on a variety of pure metals and alloys. Metals tested were those that might be applicable in heat rejection systems using high-saline water.

The apparatus used for the corrosion tests is shown in Figure 1. The coupons [ $75 \times 13 \times 3 \mathrm{~mm}$ ( $3 \times 1 / 2 \times 1 / 16$ in.)] were placed on a $15.2 \mathrm{~cm}$ disk and rotated at $21 \mathrm{rad} / \mathrm{s}(200 \mathrm{rpm})$ in $24 \mathrm{~L}$ of Raft River geothermal water chemically treated by a warm lime softening process and salted to the desired chloride concentrations. A typical water analysis is shown in Table 1. Each 26-L glass jar used in these tests was fitted with four $2.5-\mathrm{cm}$ baffles to eliminate the vortexing created by rotation at $200 \mathrm{rpm}$. The system was aerated with an air sparge and maintained at a temperature of $35^{\circ} \mathrm{C}$ $\left(95^{\circ} \mathrm{F}\right)$. The $\mathrm{pH}$ was maintained at 6.8 to 7.2 by adding dilute sulfuric acid or sodium hydroxide. Dispersants were added for scale prevention. The duration of each test was approximately 30 days, and the coupons were prepared as described below for each test.

Before being tested, the coupons were degreased and cleaned in accordance with ASTM standards for the given metal, ${ }^{1}$ after which they were attached by plastic screws to the disk, with a 1/4-in. teflon washer on either side of each coupon. Coupons were added and removed according to a planned interval test schedule $^{2}$ designed to determine whether the change in corrosion rate is due to a change in the corrosivity of the fluid or to a change in the corrodibility of the metal. Following exposure, the coupons were air dried and cleaned according to ASTM standards, weighed, and then examined with a microscope at $200 \mathrm{X}$ magnification for pit formation and depth.

\subsection{Pilot Cooling Tower Tests}

2.2.1 Test Units. The pilot cooling tower test units, shown in Figure 2, were designed to simulate operating conditions where high-chloride waters are used in evaporative cooling heat rejection systems. The cooling water circulation rate is controlled at $1.5 \mathrm{~m} / \mathrm{s}(5 \mathrm{fps})$ on the shell side of a tube and shell heat exchanger. The heat load to the cooling water is from geothermal water cooled to $60^{\circ} \mathrm{C}\left(140^{\circ} \mathrm{F}\right)$ and flows on the tube side. Flow is controlled by an actuator valve connected to a temperature-sensing probe with a set point of $35^{\circ} \mathrm{C}\left(95^{\circ} \mathrm{F}\right)$ for the heat exchanger effluent cooling water. The makeup water addition to the tower is controlled by a float in the tower basin. The $\mathrm{pH}$ and conductivity are regulated with monitor units which operate appropriate valves at predetermined set points. The typical analysis of the circulating water is listed in Table 2 .

2.2.2 Test Procedures. Tubular samples $182 \mathrm{x}$ $1.9 \mathrm{~cm} \mathrm{(6} \mathrm{ft} \times 3 / 4 \mathrm{in}$.) were used for these tests. Materials were selected primarily on the basis of performance in the screening spinner tests. The nominal chemical compositions of the tube materials are given in Table 3. The tube materials were cleaned according to ASTM standards, weighed, and inserted into the heat exchanger. Chemical additives were added to the makeup tanks to ensure deposit control during the test. Biocides were also added on a weekly basis to prevent biological fouling. The makeup water used was Raft River geothermal water chemically treated by a warm lime softening process to reduce the hardness and silica concentrations. The test continued for approximately 6 months with the nominal circulating water chemistry shown in Table 2. Tube samples were removed at the end of the test period, cleaned, weighed, and then examined with a microscope at $200 \mathrm{X}$ magnification for pit formation and depth. 


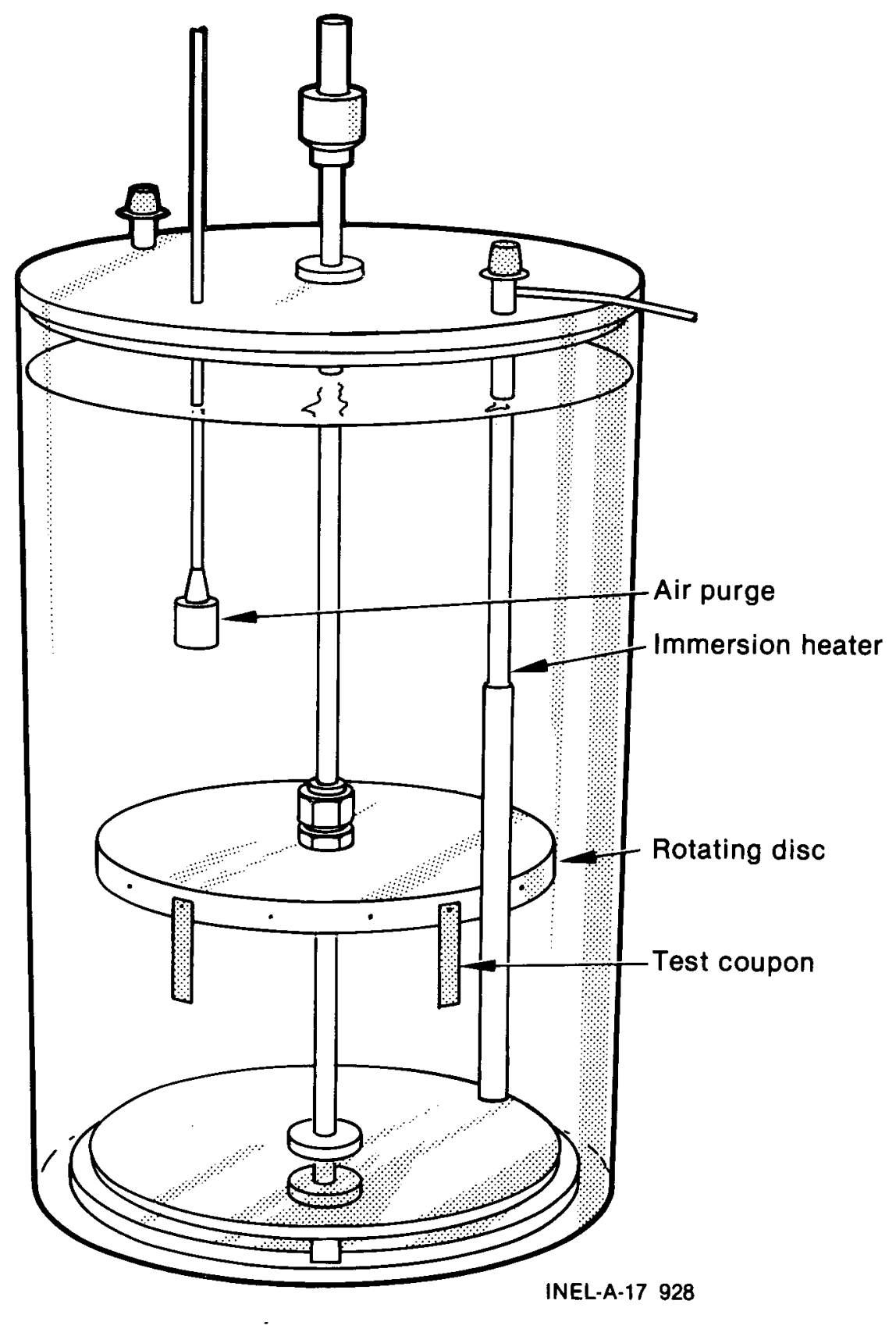

Figure 1. Spinner test apparatus. 


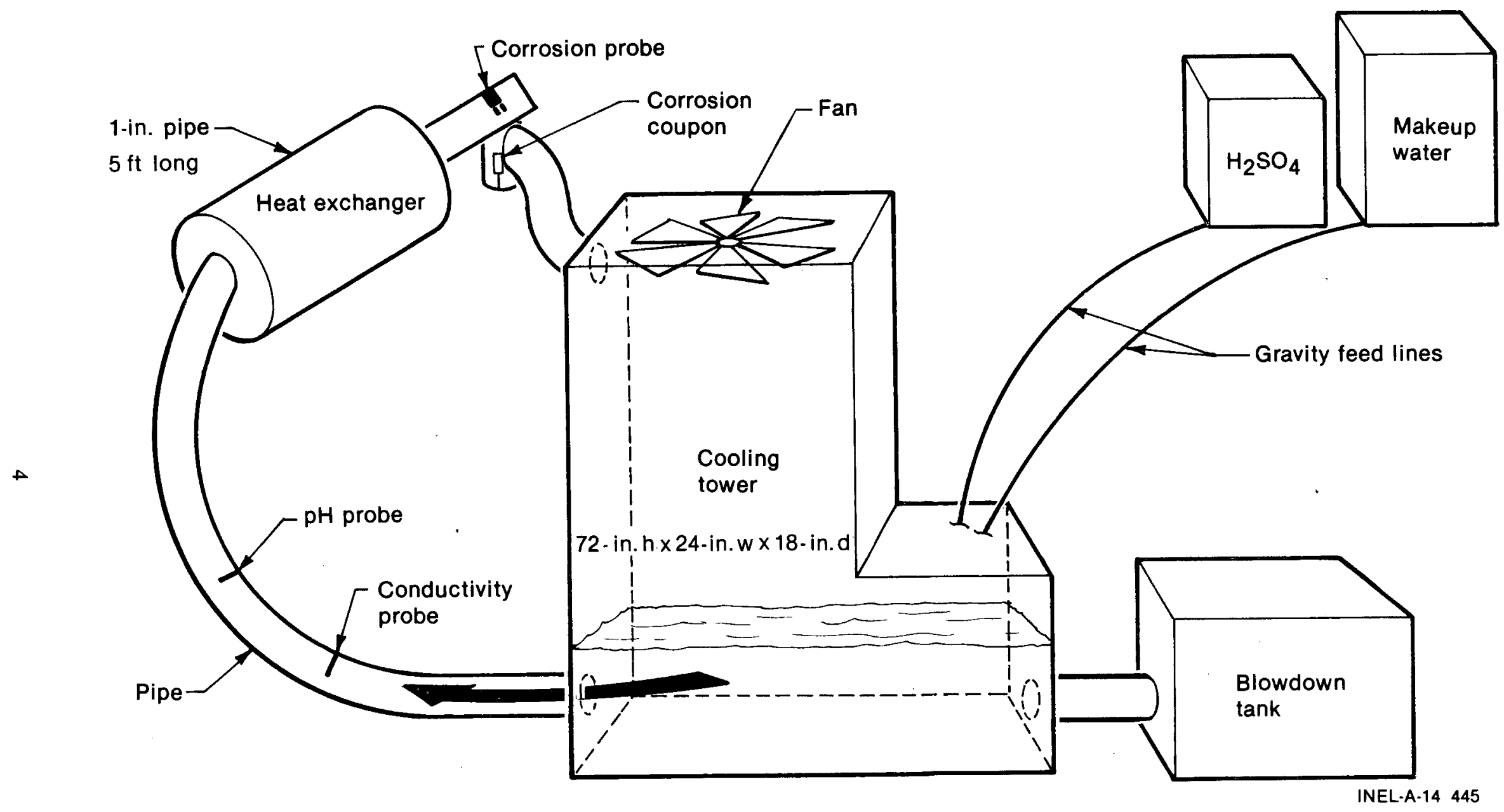

Figure 2. Pilot cooling tower test unit. 
Table 1. Typical water analysis of solutions used for spinner tests

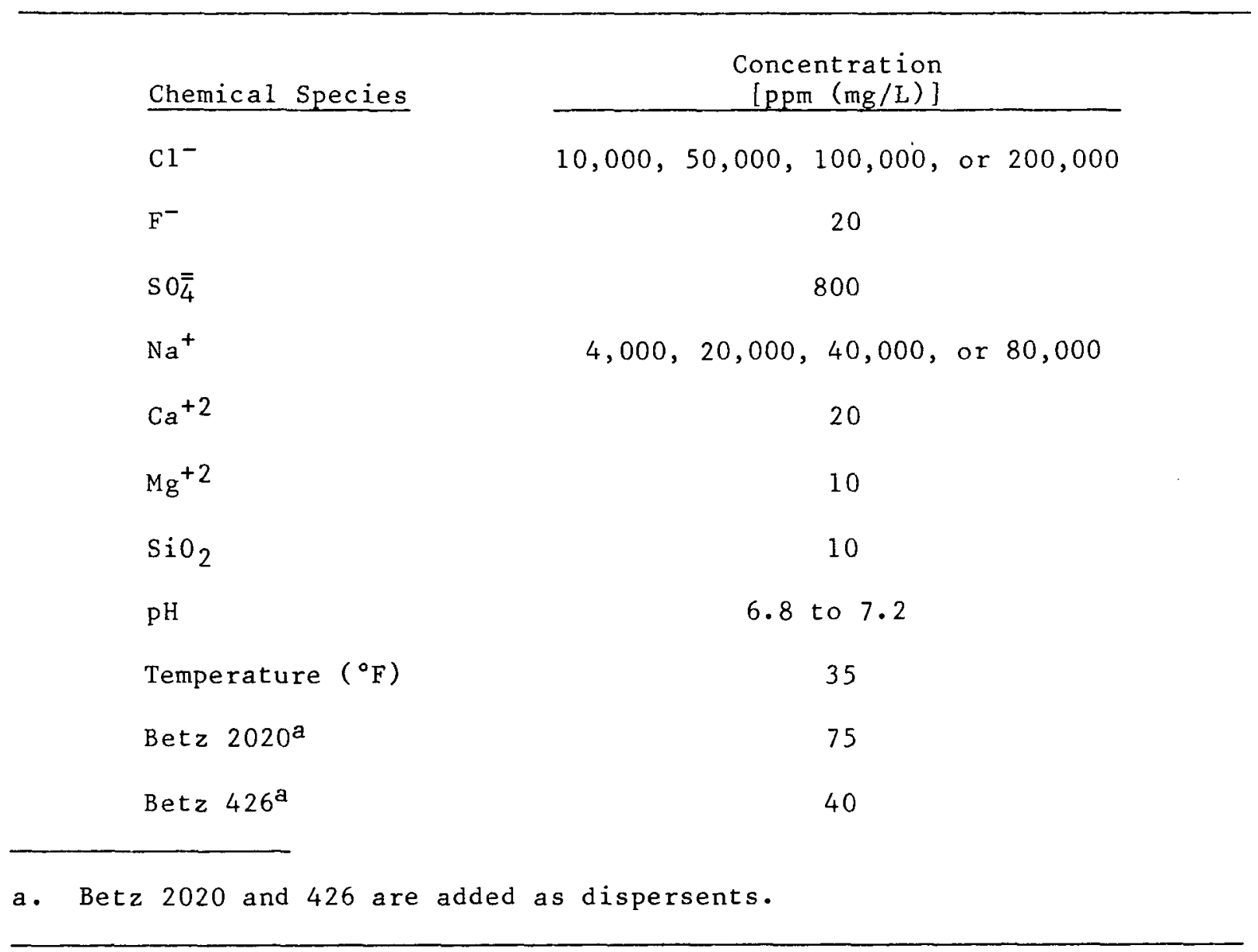


Table 2. Typical analysis of circulating water in pilot cooling tower corrosion tests

\begin{tabular}{|c|c|c|}
\hline & Chemical Species & $\begin{array}{l}\text { Concentration } \\
{[\mathrm{ppm}(\mathrm{mg} / \mathrm{L})]}\end{array}$ \\
\hline & $\mathrm{CL}^{-}$ & 35,000 \\
\hline & $\mathrm{F}^{-}$ & 23 \\
\hline & $\mathrm{SO}_{4}=$ & 3,500 \\
\hline & $\mathrm{Na}^{+}$ & 15,000 \\
\hline & $\mathrm{Ca}^{+2}$ & 100 as $\mathrm{CaCO}_{3}$ \\
\hline & $\mathrm{Mg}^{+2}$ & 20 as $\mathrm{CaCO}_{3}$ \\
\hline & $\mathrm{SiO}_{2}$ & 100 \\
\hline & $\mathrm{pH}$ & 6.8 to 7.2 \\
\hline & Temperature $\left({ }^{\circ} \mathrm{F}\right)$ & 75 to 95 \\
\hline & Betz $2020^{a}$ & 75 \\
\hline & Betz $426^{a}$ & 40 \\
\hline & Betz $562-C^{a}$ & 50 \\
\hline $\begin{array}{l}\text { a. Betz } 2020 \text { an } \\
\text { inhibitor used to }\end{array}$ & $\begin{array}{l}\text { ad } 426 \text { are dispers } \\
\text { :o prevent dissolu }\end{array}$ & $\begin{array}{l}\text { tz } 562-\mathrm{C} \text { is a copper corrosion } \\
\text { the spray nozzles and floats. }\end{array}$ \\
\hline
\end{tabular}


Table 3. Metal composition

\begin{tabular}{|c|c|c|c|c|c|c|c|c|c|c|c|c|c|c|c|c|c|c|c|c|c|c|}
\hline Metal & $\underline{\mathrm{Cu}}$ & $\mathrm{Ni}$ & $\underline{\mathrm{C}_{\mathrm{r}}}$ & Fe & $\underline{M n}$ & Al. & $\mathrm{Ti}$ & Mo & $c_{0}$ & $2 n$ & Sn & $\underline{z_{r}}$ & $\mathrm{~Pb}$ & $\mathrm{cb}$ & $v$ & $\mathrm{c}$ & $\underline{s}$ & si & $\mathrm{P}$ & $w$ & $\mathrm{~N}$ & $\underline{M_{2}}$ \\
\hline $90 / 10^{a}$ & 87.8 & 10.0 & - & 1.3 & 0.6 & -- & -- & -- & -- & -- & - & -- & -- & -- & -- & -- & -- & 0.3 & -- & -- & -. & -- \\
\hline $70 / 30$ & 69.0 & 26.95 & - & 0.55 & 0.73 & -- & -- & -- & -- & 0.02 & -- & -- & 0.007 & -- & -- & 0.03 & 0.005 & -- & 0.003 & -- & -- & -- \\
\hline Mone1 $404^{a}$ & 44 & 55 & -- & 0.05 & 0.01 & -- & -- & -- & -- & - & -- & - & -- & -- & -- & 0.06 & -- & -- & -- & -- & -- & -- \\
\hline Monel 400 & 31.23 & 66.49 & -- & 1.02 & 0.92 & 0.001 & -- & -- & -- & -- & - & -- & -- & -- & -- & 0.12 & 0.010 & 0.121 & & -- & - & -- \\
\hline Red brass ${ }^{a}$ & 85 & -- & -- & - & -- & -- & -- & -- & -- & 15 & -- & -- & -- & -- & -- & -- & -- & -- & -- & -- & - & -- \\
\hline Admiralty brass & 71 & -- & -- & -- & -- & -- & -- & -- & -- & 28 & -- & -- & -- & -- & -- & -- & -- & -- & -- & -- & - & -- \\
\hline Yellow brass ${ }^{a}$ & 65 & -- & - & -- & -- & -- & -- & -- & -- & 35 & -- & -- & -- & -- & -- & -- & -- & -- & -- & -- & -- & -- \\
\hline Muntz metal ${ }^{\varepsilon}$ & 61 & -- & -- & - & -- & -- & -- & -- & -- & 39 & -- & -- & -- & -- & -- & -- & -- & -- & -- & -- & -- & -- \\
\hline Naval brass ${ }^{\mathrm{a}}$ & 60.5 & -- & - & -- & -- & -- & -- & -- & -- & 38.75 & 0.75 & -- & -- & -- & -- & -- & -- & -- & -- & - & -- & -- \\
\hline Aluminum bronze $\mathrm{e}^{\mathrm{a}}$ & 90.5 & -- & -- & 2.5 & -- & 7 & -- & -- & -- & -- & -- & -- & -- & -- & -- & -- & -- & -- & -- & -- & -- & -- \\
\hline AmpCo $8 \mathrm{~F}$ & 90.30 & - & -- & 2.42 & -- & 6.90 & -- & -+ & -- & -- & 0.25 & -- & -- & -- & -- & -- & -- & -- & -- & -- & -- & -- \\
\hline AmpCo $483 \mathrm{P}$ & 81.67 & 4.64 & -- & 4.06 & 0.92 & 8.64 & -- & -- & -- & -- & -- & - & -- & -- & -- & -- & -- & -- & -- & -- & -- & -- \\
\hline AmpCo 12SF & 88.25 & -- & -- & 2.78 & -- & 8.87 & -- & -- & -- & -- & -- & -- & -- & -- & -- & -- & -- & -- & -- & -- & -- & -- \\
\hline High-silicon bronze & 95.7 & -- & $\cdots$ & 0.025 & 1.07 & -- & -- & -- & -- & 0.18 & -- & -- & 0.005 & -- & -- & -- & -- & 3.0 & -- & -- & 0.018 & -- \\
\hline Phosphorus bronze & 89.8 & -- & - & -- & - & -- & -- & -- & -- & -- & 10 & -- & -- & -- & -- & -- & -- & -- & 0.2 & -- & -- & -- \\
\hline Sandvik SAN 28 & -- & 31.80 & 24.80 & 38.03 & 1.78 & -- & - & 3.51 & -- & -- & -- & -- & -- & -- & -- & 0.017 & 0.004 & 0.10 & 0.016 & -- & 0.36 & -- \\
\hline $\begin{array}{l}\text { Sandvik SAF } 2205 \\
\text { Sand }\end{array}$ & $\overline{--}$ & $\begin{array}{r}5.55 \\
24.50\end{array}$ & 22.04 & $\begin{array}{r}67.30 \\
-46.94\end{array}$ & 1.53 & $\overline{--}$ & $-\overline{-}$ & 2.96 & $\overline{-}$ & -- & -- & - & & -- & - & 0.017 & 0.003 & 0.43 & 0.022 & -- & 0.014 & -- \\
\hline Al legheny $6 \mathrm{x}^{\mathrm{a}}$ & -- & 24.50 & 20.25 & 46.94 & 1.50 & -- & -- & 6.25 & -- & -- & -- & -- & -- & -- & -- & 0.025 & 0.010 & 0.50 & 0.025 & -- & -- & -- \\
\hline Carpenter $20 \mathrm{CB} 3$ & 3.5 & 34 & 20 & 39.4 & -- & -- & - & 2.5 & -- & - & -- & -- & -- & 0.6 & -- & -- & -- & -- & .. & -- & -- & -- \\
\hline 304 stainless & 0.11 & 8.25 & 18.26 & 70.84 & 1.65 & - & -- & 0.15 & - & -- & -- & - & -- & - & -- & 0.07 & 0.008 & 0.57 & 0.018 & - & 0.074 & - \\
\hline 309 stainless & 0.13 & 14.72 & 22.24 & 59.87 & 1.85 & -- & -- & 0.14 & -- & -- & -- & -- & -- & -- & - & 0.059 & 0.005 & 0.70 & 0.12 & - & -- & - \\
\hline 310 stainless & 0.28 & 20.15 & 24.90 & 52.06 & 1.71 & -- & -- & 0.21 & 0.18 & -- & -- & -- & -- & -- & -- & 0.058 & 0.009 & 0.40 & 0.019 & -- & 0.025 & -- \\
\hline 316 stainless ${ }^{a}$ & -- & 12.0 & 17 & 68.7 & -- & -- & -- & 2.25 & - & - & -- & -- & -- & -- & -- & 0.08 & - & -- & -- & -- & -- & -- \\
\hline 439 stainless & -- & 0.50 & 18.25 & 78.160 & 1.00 & 0.15 & 0.70 & -- & -- & -- & -- & -- & -- & -- & -- & 0.07 & 0.03 & 0.40 & 0.30 & -- & -- & -- \\
\hline 410 stainless & 0.11 & 0.34 & 12.36 & 86.07 & 0.37 & 0.007 & -- & 0.14 & 0.23 & -- & -- & -- & -- & -- & -- & 0.18 & 0.005 & 0.43 & -- & -- & 0.022 & -- \\
\hline $440 \mathrm{~A}$ stainless $\mathrm{a}$ & -- & -- & 18.00 & 78.16 & 1.0 & -- & -- & 0.75 & -- & -- & -- & -- & -- & -- & -- & 0.75 & 0.03 & 1.0 & 0.040 & -- & -- & -- \\
\hline SEA-CURE & 0.20 & $-\infty$ & 26.30 & 67.72 & 0.33 & -- & 0.31 & 3.00 & -- & -- & -- & -- & -- & -- & -- & 0.008 & 0.007 & -- & 0.022 & -- & -- & -- \\
\hline $29-4^{a}$ & -- & 0.15 & & & -- & -- & -- & & -- & -- & -- & -- & -- & -- & -- & 0.01 & -- & -- & -- & -- & -- & -- \\
\hline $\begin{array}{l}29-4-2^{a} \\
29-4-C^{a}\end{array}$ & $=$ & $\begin{array}{l}2.0 \\
0.30\end{array}$ & $\begin{array}{l}29 \\
29\end{array}$ & $\begin{array}{l}63.99 \\
65.24\end{array}$ & 0.50 & $\overline{--}$ & -- & $\begin{array}{l}4.0 \\
4.0\end{array}$ & $0 .-\overline{03}$ & -- & -- & $\begin{array}{l}-- \\
--\end{array}$ & $\overline{--}$ & $\begin{array}{l}-- \\
--\end{array}$ & $\overline{--}$ & $\begin{array}{l}0.01 \\
0.02\end{array}$ & 0.01 & $0 . \overline{35}$ & $\overline{0.03}$ & -- & 0.02 & $\begin{array}{l}-- \\
--\end{array}$ \\
\hline Ferralium & 1.7 & 5.5 & 26 & 62.34 & 0.8 & -- & $\ldots$ & 3.0 & -- & -- & -- & -- & $\ldots$ & $\ldots$ & $\ldots$ & 0.04 & $\ldots$ & 0.45 & -- & $\ldots$ & 0.17 & $\ldots$ \\
\hline $\begin{array}{l}\text { Ferralum } \\
\text { Haste1loy } x^{a}\end{array}$ & & 48 & 22 & 18.5 & & -- & -- & 9 & 1.5 & -- & -- & -- & -- & -- & -- & 0.15 & - & - & -- & 0.6 & -- & -- \\
\hline Hastelloy $G^{a}$ & 2 & 47.5 & 22 & 20 & 6.5 & -- & -- & -- & - & - & -- & - & -- & -- & - & -- & -- & -- & -- & -0 & - & - \\
\hline Incoloy 800 & 0.59 & 32.32 & 19.44 & 45.48 & 0.87 & 0.33 & 0.48 & -- & -- & -- & -- & -- & -- & -- & -- & 0.03 & 0.002 & 0.46 & -- & -- & -- & -- \\
\hline Incoloy $825^{\mathrm{a}}$ & 4.8 & 41.8 & 21.5 & 30.0 & -- & 0.15 & 0.9 & 3.0 & -- & -- & -- & -- & -- & -- & -- & 0.03 & $\ldots$ & -- & -- & - & - & - \\
\hline Inconel 600 & 0.14 & 74.96 & 15.21 & 9.20 & 0.04 & -- & -- & -- & -- & -- & -- & -- & -- & -- & -- & 0.04 & 0.001 & 0.021 & -- & -- & -- & -- \\
\hline Inconel 625 & - & 60.85 & 21.58 & 4.85 & 0.14 & 0.13 & 0.024 & 8.38 & -- & -- & -- & -- & 3.42 & -- & -- & 0.02 & 0.001 & 0.38 & 0.008 & -- & -- & -- \\
\hline Carbon steel ${ }^{\mathrm{a}}$ & ${ }^{*}-$ & -- & -- & & & -- & +- & -- & -- & -- & -- & -- & -- & -- & -- & 0.2 & - & 0.25 & -- & -- & -- & -- \\
\hline High-silicon cast iron & -- & -- & -- & 93.2 & 0.33 & -- & -- & -- & -- & -- & -- & - & -- & -- & -- & 3.37 & 0.031 & 3.05 & 0.025 & -- & -- & -- \\
\hline $9 \mathrm{Cr}_{\mathrm{r}}-1 \mathrm{Mo}$ & 0.03 & 0.04 & 8.47 & 89.46 & 0.26 & 0.031 & 0.006 & 0.94 & 0.017 & -- & -- & -- & -- & 0.190 & 0.44 & 0.11 & 0.010 & 0.29 & 0.007 & 0.10 & -- & -- \\
\hline Aluminum $1100^{2}$ & -- & -- & -- & -- & -- & 99.0 & -- & -- & -- & -- & -- & -- & - & -- & -- & -- & -- & -- & -- & -- & -- & -- \\
\hline Alumi num $6061^{\text {a }}$ & 0.25 & -- & 0.25 & -- & -- & 97.9 & -- & -- & -- & -- & -- & -- & -- & -- & -- & -- & - & 0.6 & -- & -- & -- & 1.0 \\
\hline Pure coppera & 99.90 & -- & -- & -- & -- & -- & -- & -- & -- & -- & -- & -- & -- & -- & -- & -- & - & -- & -- & -- & -- & -- \\
\hline & 0.01 & 99.7 & -- & 0.02 & 0.23 & $=$ & $=-$ & -- & -- & -- & -- & -- & -- & -- & -- & 0.03 & 0.004 & 0.02 & -- & -- & -- & -- \\
\hline zirc & $=$ & $=$ & $=$ & 0.07 & -- & $=$ & -- & 99.99 & $=$ & $\because$ & $\bar{z}$ & 99.9 & -- & $=$ & -- & 0.02 & 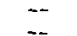 & -- & $\overline{-z}$ - & $\overline{--}$ & 0.006 & $\overline{--}$ - \\
\hline Molybdenum & $=$ & $\overline{-}$ & $\overline{--}$ & 0.09 & -- & -- & $99-87$ & 99.99 & $\because$ & -- & $=$ & -- & -- & $\because$ & $=$ & -- & $=$ & $=-$ & $=$ & -- & $-\overline{0 .}$ & -- \\
\hline $\begin{array}{l}\text { Titanium } \\
2 \text { inc }\end{array}$ & -- & $=$ & $\overline{--}$ & $\stackrel{0.09}{--}$ & 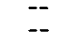 & $\overline{--}$ & $\begin{array}{c}99.87 \\
--\end{array}$ & $=$ & $=$ & 99.92 & $=-$ & $\begin{array}{l}-- \\
--\end{array}$ & $\overline{0.08}$ & -- & -- & $\begin{array}{l}0.019 \\
--\end{array}$ & $\overline{--}$ & -- & $=$ & $=$ & $\stackrel{0.013}{--}$ & 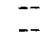 \\
\hline
\end{tabular}




\section{TEST RESULTS AND DISCUSSION}

The following discussion is derived from weight loss data and from microscopic examination for pit formation, pit depth, and crevice corrosion. Corrosion of the metals tested after 1 month of corrosion testing in the spinner test apparatus is given in Table 4. Table 5 shows general corrosion of the metals with time during testing in the spinner test apparatus. Tables 4 and 5 are presented at the end of Section 3. No metallography was conducted on the metals.

\subsection{Corrosion Tests at 10,000 ppm Chloride}

3.1.1 Copper-Nickel Alloys. Copper-nickel alloys tested at 10,000 ppm chloride were pure copper, $90 / 10,70 / 30$, Monel 404, Monel 400, and Nickel 200. The corrosion rate of $70 / 30$ and Nickel 200 were comparable (Figure 3 ). These metals were the most corrosion-resistant of the series. Pure copper had a corrosion rate twice that of $70 / 30$ or Nickel 200. The corrosion rate increased in the order of Monel 400,90/10, and Monel 404, and the corrosion of Monel 404 was four times that of $70 / 30$ or Nickel 200. A comparison of the composition of these alloys indicates a ratio range of nickel to copper that increases corrosion resistance in the highsaline environment. If the ratio is low $(90 / 10)$ or high (44/55, as in Monel 404), corrosion increases. Apparently the nickel in $90 / 10$ acts as an impurity. All the copper-nickel alloys exhibited a tendency to crevice corrode. Examination of the coupons for pitting showed that some pitting occurred in all the alloys. The maximum pit depth, $22 \mu \mathrm{m}$, occurred in Monel 404. The 70/30 and 90/10 alloys had maximum pit depth of 6 and $10 \mu \mathrm{m}$, respectively. In general, the corrosivity of the water increased with time, while the corrosion rate of the metals decreased with time.

3.1.2 Copper-Zinc Alloys. The copper-zinc alloys tested were Red Brass, Yellow Brass, Admiralty Brass, Naval Brass, and Muntz Metal. At 10,000 ppm chloride, Red Brass (Figure 4) showed the lowest corrosion rate, with a rate comparable to that of pure copper. Increasing the zinc content to that of Admiralty Brass and Yellow Brass increased the corrosion rate. The Yellow Brass corrosion rate was five times that of Red Brass, approaching the corrosion rate for zinc. Naval Brass and Muntz Metal (Figure 5) also approached the corrosion behavior of zinc. Both have similar copper and zinc content, but Naval Brass has $0.75 \%$ tin. The corrosion rate of Muntz Metal was 1-1/3 times as great as that of the Naval Brass. Red Brass and Admiralty Brass showed some crevice corrosion and pitting, with a maximum pit depth of $10 \mu \mathrm{m}$.

3.1.3 Bronzes. The bronzes tested were aluminum bronze, high-silicon bronze, AmpCo 8F, AmpCo 483P, AmpCo 12SF, and phosphorus bronze. Aluminum bronze and high-silicon bronze (Figure 6) exhibited corrosion rates at least three times greater than those for the AmpCo metals (Figure 7). Comparison of the results for the AmpCo metals (Figure 7) shows that the AmpCo 8F is the most corrosion resistant. The only difference in composition between aluminum bronze, AmpCo 12SF, and AmpCo 8F is the presence of $0.25 \%$ tin in the AmpCo 8F. This, however, seems to greatly reduce the corrosion of the metal. The corrosion resistance of the AmpCo 483P alloy seems to be influenced by the presence of manganese and nickel. All the aluminum bronze alloys exhibited pitting. The maximum pit depths for AmpCo 8F, AmpCo 12SF, AmpCo 483P, and aluminum bronze were $4,10,14$, and $14 \mu \mathrm{ms}$, respectively. Although aluminum bronze had fewer pits, the maximum pit depth was $32 \mu \mathrm{m}$. AmpCo 483P, aluminum bronze, and high-silicon bronze showed a tendency to crevice corrode. Phosphorus bronze, which has $10 \%$ tin and $0.2 \%$ phosphorus, was the most corrosion resistant of the bronzes, with a corrosion rate of $3.13 \mathrm{mdd}$ (0.51 mpy) after 30-days exposure. Although phosphorus bronze exhibited slight crevice corrosion, there was no apparent pitting.

3.1.4 Austenitic Stainless Steels. The austenitic stainless steels examined were Sandvik SAN28 and SAF2205, Allegheny 6X, Carpenter 20CB3, 304, $309,310,316$, and 439 . Generally the austenitic stainless steel (Figure 8) exhibited general corrosion rates comparable to that of the $70 / 30$ copper-nickel alloy. The 439 alloy exhibited the most general corrosion. The two Sandvik metals were similar. The 309 and 310 alloys lost no weight. The general corrosion rate increased as follows: 304, 316, Carpenter, 20CB3, Allegheny 6X, then the Sandvik alioys. The three alloys $(309,310$, and 304$)$ that showed no weight loss or very little were the only austenitics in which pitting occurred. The pit density ranged from 3 to 10 pits per $\mathrm{cm}^{2}$, with a maximum depth of $20 \mu \mathrm{m}$. 
3.1.5 Martensitic Stainless Steels. Martensitic stainless steels tested were 410 and $440 \mathrm{~A}$. In general, the corrosion rates were 10 times as great as those for the austenitic stainless steels. As can be seen in Figure 9, the corrosion increased linearly for the 30 -day tests. The final weight loss for the 410 alloy, however, was 1.5 times greater than for $440 \mathrm{~A}$. Both alloys showed a tendency to crevice corrode and pit. The maximum pit depth was $2 \mu \mathrm{m}$ for 410 and $28 \mu \mathrm{m}$ for $440 \mathrm{~A}$.

3.1.6 Ferritic Stainless Steels. The ferritic stainless steels examined were SEA-CURE, 29-4, 29-4-2, and 29-4-C. The only alloy showing general corrosion was the SEA-CURE (Figure 10). This metal was comparable to the $70 / 30$ copper-nickel alloy. However, the SEA-CURE, 29-4, and 29-4-2 did not show any tendency to pit or crevice corrode. The 29-4-C alloy, although showing no general corrosion, did exhibit some pitting, with a maximum pit depth of $8 \mu \mathrm{m}$.

Ferralium 255, a ferritic-austenitic stainless steel, was also examined. This alloy exhibited corrosion similar to that of the SEA-CURE alloy or Allegheny 6X.

3.1.7 Nickel-Base Alloys. The nickel-base alloys tested were Hastelloy X, Hastelloy G, Incoloy 800 and 825, and Inconel 600 and 625 . Although these alloys exhibited excellent corrosion resistance, their high cost prevents their use as condenser material unless the lower cost materials fail to show good corrosion resistance. The results are shown in Figure 11. There was little difference in the general corrosion of the metals in this group. The corrosion was comparable to that of the austenitic metals. Inconel 600 had the highest corrosion, and Incoloy 825 the lowest. All the alloys except Incoloy 800 exhibited pitting corrosion, with a maximum pit depth of $10 \mu \mathrm{m}$. Incoloy 800 showed a tendency to crevice corrode.

3.1.8 Miscellaneous Ferrous Metals. The miscellaneous metals included carbon steel, highsilicon cast iron, and $9 \mathrm{Cr}-1 \mathrm{Mo}$. All suffered severe general and crevice corrosion. Pitting of the $9 \mathrm{Cr}-1$ Mo occurred as large pits in the metal that were visible without a microscope. The width of the pits made it impossible to measure the pit depth. The severity of the general corrosion on the other two metals also made pit determinations impossible since there was little of the original surface remaining for comparison.
3.1.9 Aluminum Alloys. Aluminum 1100 and 6061 were tested at $10,000 \mathrm{ppm}$ chloride (Figure 12). Both metals exhibited severe general corrosion and pitting, with the pits covering large areas. Before being cleaned after the test, the coupons were covered with a white deposit. Those coupons put in at the end of the test period did not have these deposits, and did not exhibit the extreme general or pitting corrosion.

3.1.10 Pure Metals. The pure metals tested were Nickel 200, copper, titanium, zirconium, molybdenum, and zinc. Nickel 200, copper, and titanium (Figure 13) exhibited good resistance to general corrosion. The general corrosion of the remaining metals increased as follows: zirconium, zinc, and molybdenum. Titanium, copper, and zinc exhibited pitting. With titanium, the pits reached a maximum depth of $20 \mu \mathrm{m}$. Zirconium and molybdenum did not exhibit any pitting. Copper suffered slight crevice corrosion, and zinc suffered severe crevice corrosion.

3.1.11 Coated Steels. Two coated carbon steels from AMF Tuboscope, Inc., were tested in the spinner test. The coatings were TK2, a straight phenolic coating, and TK7, a modified phenolic coating. Both exhibited excellent corrosion resistance on the main surface of the coupons. The only corrosion that occurred was on the sharp edges where the coating had cracked.

\subsection{Corrosion Tests at 50,000 ppm Chloride}

3.2.1 Copper-Nickel Alloys. Corrosion resistances of the copper-nickel alloys were determined at $50,000 \mathrm{ppm}$ chlorides for pure copper, $90 / 10,70 / 30$, and Monel 400. Increasing the chloride concentration to $50,000 \mathrm{ppm}$ chloride increased the corrosion rate for all of these alloys (Figures 14 and 15), but the rate of increase was not the same for all of them. The corrosion rate of $70 / 30$ increased by a factor of 0.5 , while the rate for pure copper increased by 1.25 . The maximum pit depth also increased for these alloys. The $90 / 10$ alloy showed the largest increase in general corrosion but exhibited only a few pits, with depths of 3 to $5 \mu \mathrm{m}$.

3.2.2 Copper-Zinc Alloys. Red Brass, Admiralty Brass, and Yellow Brass were tested at 50,000 ppm chloride. The brasses (Figure 16) generally exhibited corrosion rates about fives times greater than those 
at $10,000 \mathrm{ppm}$ chloride. Both Red Brass and Admiralty exhibited crevice corrosion. Admiralty also exhibited pitting, but there was no increase in depth over that at $10,000 \mathrm{ppm}$ chloride. Neither Yellow Brass nor Red Brass pitted. Yellow Brass, however, had large areas of general corrosion.

3.2.3 Bronzes. Phosphorus bronze, AmpCo 8F, 483P., and 12SF were tested at 50,000 ppm chloride (Figure 17). AmpCo 8F was tested for 2 months (Figure 18). Its corrosion rate was twice that at $10 ; 000 \mathrm{ppm}$ chloride. AmpCo 483P and phosphorus bronze had essentially the same corrosion rate as at 10,000 ppm chloride.

3.2.4 Austenitic Stainiless Steels. The only austenitic stainless steel tested at 50,000 ppm chloride was Allegheny $6 \mathrm{X}$. In general, there was no significant difference in the corrosion rate at 10,000 ppm chloride and at $50,000 \mathrm{ppm}$ chloride (Figure 19).

3.2.5 Ferritic Stainless Steels. The ferritic stainless steels examined at 50,000 ppm chloride were SEA-CURE, 29-4, 29-4-2, and 29-4-C. At $50,000 \mathrm{ppm}$ chloride, there was essentially no change in the corrosion rate of the SEA-CURE, 29-4, or 29-4-C (Figure 20). 29-4-2, however, did show some general corrosion. The corrosion was about the same as that for SEA-CURE. General corrosion of Ferralium 255 was similar to that of 29-4 and 29-4-2, but the Ferralium also exhibited crevice corrosion.

3.2.6 Pure Metals. The pure metals tested at $50,000 \mathrm{ppm}$ chloride were copper, Nickel 200, and titanium. The corrosion rate of copper was increased by a factor of 1.25 in the $50,000 \mathrm{ppm}$ chloride water (Figure 21). The corrosion rate of nickel was less than at $10,000 \mathrm{ppm}$ chloride, but some crevice corrosion did occur. The general corrosion rate for titanium did not increase, and although there was an increase in the number of pits noted, there was no increase in the depth of the pits.

\subsection{Corrosion Tests at 100,000 ppm Chloride}

3.3.1 Copper-Nickel Alloys. The copper-nickel alloys examined at 100,000 ppm chloride were $90 / 10,70 / 30$, and Monel 400 . The corrosion rate of $90 / 10$ during this test was so high that the test was discontinued after 1 week. During the 1 week period, the corrosion rate for $90 / 10$ was 71.73 mdd (11.5 mpy). Monel 400 was the most corrosion resistant, with a corrosion rate of $2.72 \mathrm{mdd}(0.44 \mathrm{mpy})$ (Figure 22). The corrosion rate of $70 / 30$ was approximately five times greater. Both $70 / 30$ and Monel 400 exhibited crevice corrosion. Both also exhibited pitting, but there was no increase in number or depth over that encountered at $50,000 \mathrm{ppm}$ chloride. The 90/10 alloy did not exhibit pitting, but did show severe areas of general corrosion that were visible without the microscope.

3.3.2 Copper-Zinc Alloys. The copper-zinc alloys tested at 100,000 ppm chloride were Red Brass, Yellow Brass, and Admiralty Brass. All exhibited severe general corrosion, and the tests were discontinued after 1 week.

Although all of the copper-zinc alloys suffered general corrosion severe enough so that very little of the original surface remained, none of them exhibited pitting. The corrosion rates were 222.9 mdd (36.6 mpy) for Red Brass, $100.9 \mathrm{mdd}$ (17.0 mpy) for Admiralty Brass, and $117.2 \mathrm{mdd}$ (19.9 mpy) for Yellow Brass.

3.3.3 Bronzes. Phosphorus bronze was tested at $100,000 \mathrm{ppm}$ chloride. The test was discontinued after 1 week because of the high general corrosion rate experienced by this alloy.

3.3.4 Austenitic Stainless Steels. The only austenitic stainless steel tested at $100,000 \mathrm{ppm}$ chloride was Allegheny $6 \mathrm{X}$. This alloy did not exhibit any general corrosion following the 4-week exposure, and no pitting or crevice corrosion was apparent.

3.3.5 Ferritic Stainless Steels. The ferritic stainless steels examined at $100,000 \mathrm{ppm}$ chloride were SEA-CURE, 29-4, 29-4-2, and 29-4-C. SEACURE and 29-4 were the only alloys exhibiting any weight loss. The corrosion rate of SEA-CURE was 0.05 mdd $(0.01 \mathrm{mpy})$ after 4 weeks of exposure. This rate is approximately $1 / 20$ th of the rate encountered at $50,000 \mathrm{ppm}$. The $29-4$ alloy showed greater general corrosion at $100,000 \mathrm{ppm}$ than at $50,000 \mathrm{ppm}$. This alloy also exhibited crevice corrosion. None of the ferritic stainless steels exhibited pitting at 100,000 ppm chloride. Corrosion of Ferralium 255 was similar to that of $29-4$.

3.3.6 Pure Metals. Nickel 200 and pure copper were examined at $100,000 \mathrm{ppm}$ chloride. The pure 
copper test was discontinued after 1 week because of the severe general corrosion exhibited. Nickel 200 exhibited general corrosion only" slightly greater [0.93 mdd $(0.15 \mathrm{mpy})]$ than at $50,000 \mathrm{ppm}$ chloride [0.48 mdd (0.08 mpy)].

\subsection{Corrosion Tests at 200,000 ppm Chloride}

3.4.1 Copper-Nickel Alloys. Monel 400 was the only copper-nickel alloy tested at $200,000 \mathrm{ppm}$ chloride. The alloy exhibited less general corrosion than at 100,000 ppm chloride and showed only slight crevice corrosion.

3.4.2 Austenitic Stainless Steels. Allegheny 6X was examined at $200,000 \mathrm{ppm}$ chloride. This alloy exhibited no general or crevice corrosion.

3.4.3 Ferritic Stainless Steels. The only alloy tested at 200,000 ppm chloride was SEA-CURE. This alloy exhibited no general, crevice, or pitting corrosion.

3.4.4 Pure Metals. Nickel 200 was the only pure metal examined at $200,000 \mathrm{ppm}$ chloride. The general corrosion was similar to that at $100,000 \mathrm{ppm}$ chloride. Some crevice corrosion, however, was exhibited.

\subsection{Pilot Cooling Tower Tests}

Four materials were tested in the initial 6-month tests. These were 70/30 copper-nickel, Admiralty Brass, SEA-CURE, and a $12 \mathrm{Cr}$ alloy. The SEACURE and 70/30 copper nickel had corrosion rates of 1.21 and 2.17 mdd ( 0.22 and $0.35 \mathrm{mpy}$ ), respec- tively, with no pitting. The $12 \mathrm{Cr}$ alloy and the Admiralty Brass had corrosion rates of 9.57 and 1.48 mdd (1.76 and 0.25 mpy), respectively. The Admiralty Brass apparently dealloyed, and the $12 \mathrm{Cr}$ alloy had pits larger than $0.64 \mathrm{~cm}(0.25 \mathrm{in}$.) in diameter and $0.13 \mathrm{~cm}(0.05 \mathrm{in}$.$) in depth.$

The SEA-CURE and 70/30 copper-nickel were then reinserted for an additional 4 months. The Admiralty Brass and the $12 \mathrm{Cr}$ alloy were replaced by $90 / 10$ and carbon steel. The $90 / 10$ and the carbon steel showed corrosion rates of 1.87 and $21.72 \mathrm{mdd}$ ( 0.3 and 4.0 mpy), respectively, after 4 months of exposure. Carbon steel exhibited crevice corrosion and pitting corrosion, with pits larger than $0.64 \mathrm{~cm}$ $(0.25 \mathrm{in}$.$) in diameter and 0.08 \mathrm{~cm}(0.03 \mathrm{in}$.) in depth. The 90/10 alloy dealloyed and showed pitting corrosion. The SEA-CURE and 70/30 had corrosion rates of 0.93 and $1.18 \mathrm{mdd}(0.17$ and $0.19 \mathrm{mpy})$, respectively. After 10 months of exposure, neither of these materials exhibited pitting or crevice corrosion. The surface of both alloys was the same as before exposure.

In the third test, Allegheny 6X, 29-4-C, Monel 400 , aluminum brass, and Ferralium 255 were examined. Ferralium 255 and 29-4-C exhibited the least general corrosion [2.66 and 1.59 mdd $(0.49$ and $0.29 \mathrm{mpy})]$ with no crevice or pitting corrosion. Allegheny $6 \mathrm{X}$, Monel 400, and aluminum brass all showed general corrosion, with aluminum brass exhibiting the most [6.39 mdd (1.08 mpy)]. Aluminum brass did not exhibit pitting corrosion. Allegheny $6 \mathrm{X}$ had scattered pits approximately $0.64 \mathrm{~cm}(0.25$ in. $)$ in diameter and $0.04 \mathrm{~cm}$ (0.016 in.) deep. Monel 400 had scattered pits visible with a magnifying light. The results of the pilot cooling tower tests are summarized in Table 6. 


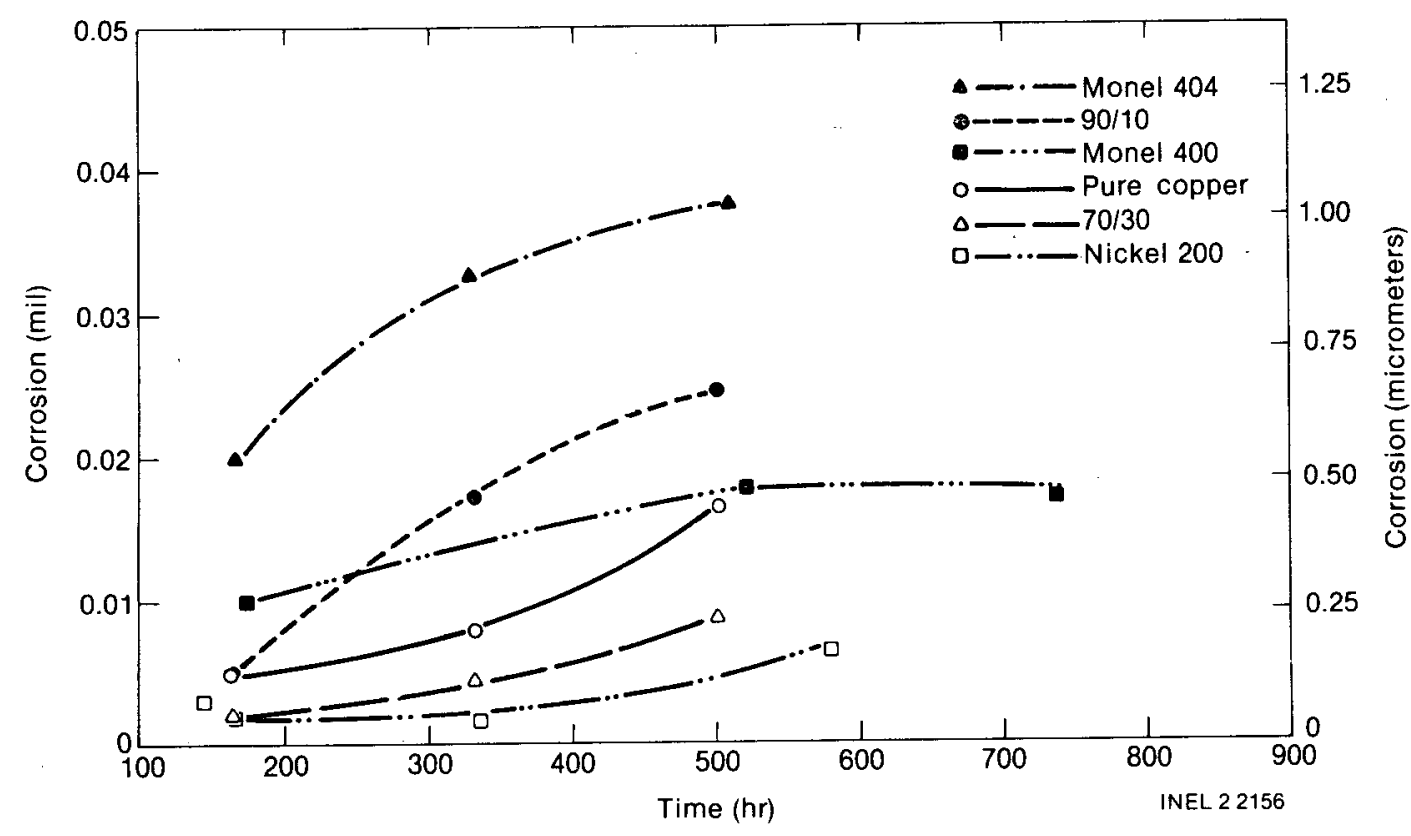

Figure 3. Copper-nickel alloys at 10,000 ppm chloride.

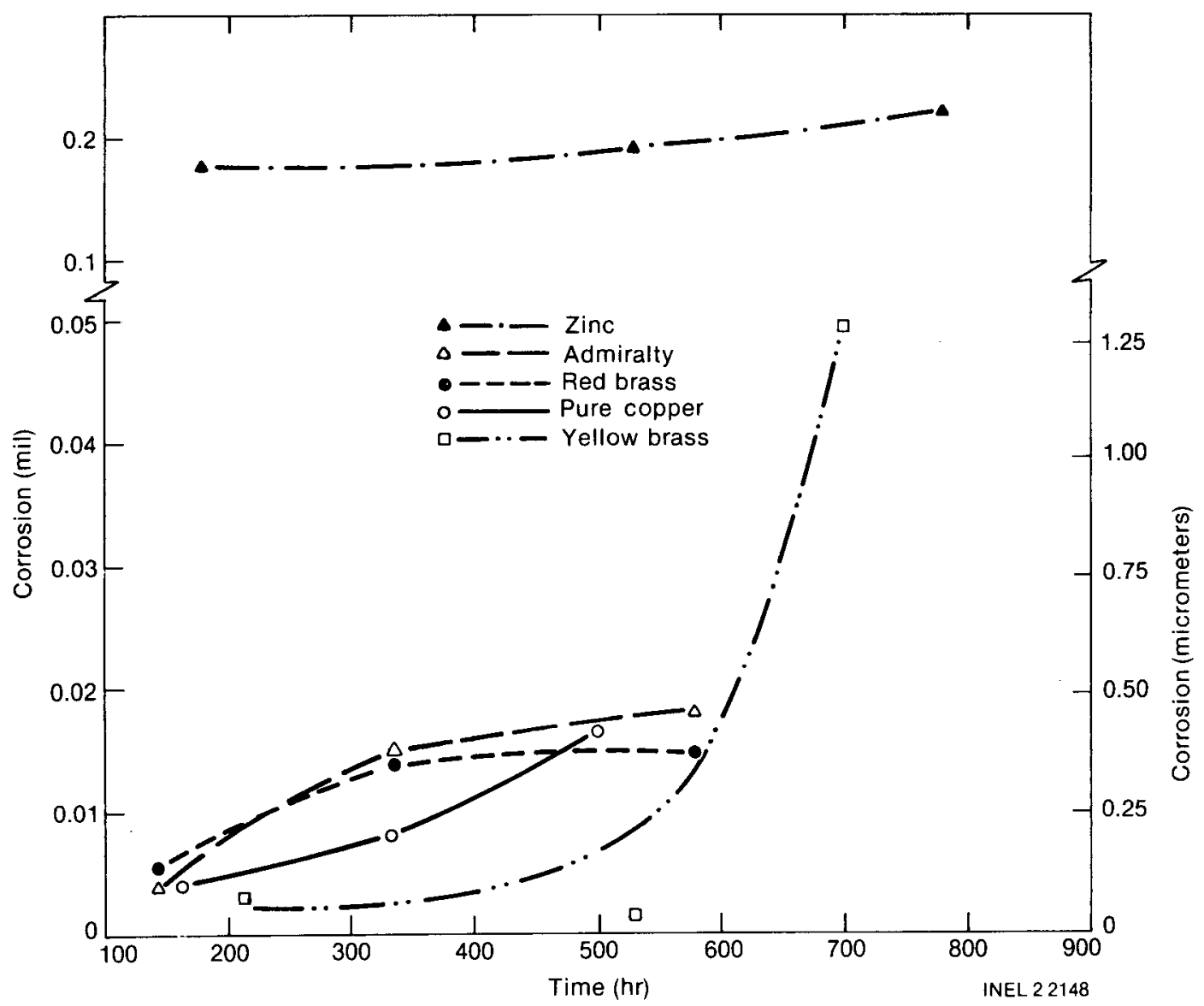

Figure 4. Copper-zinc alloys at 10,000 ppm chloride. 


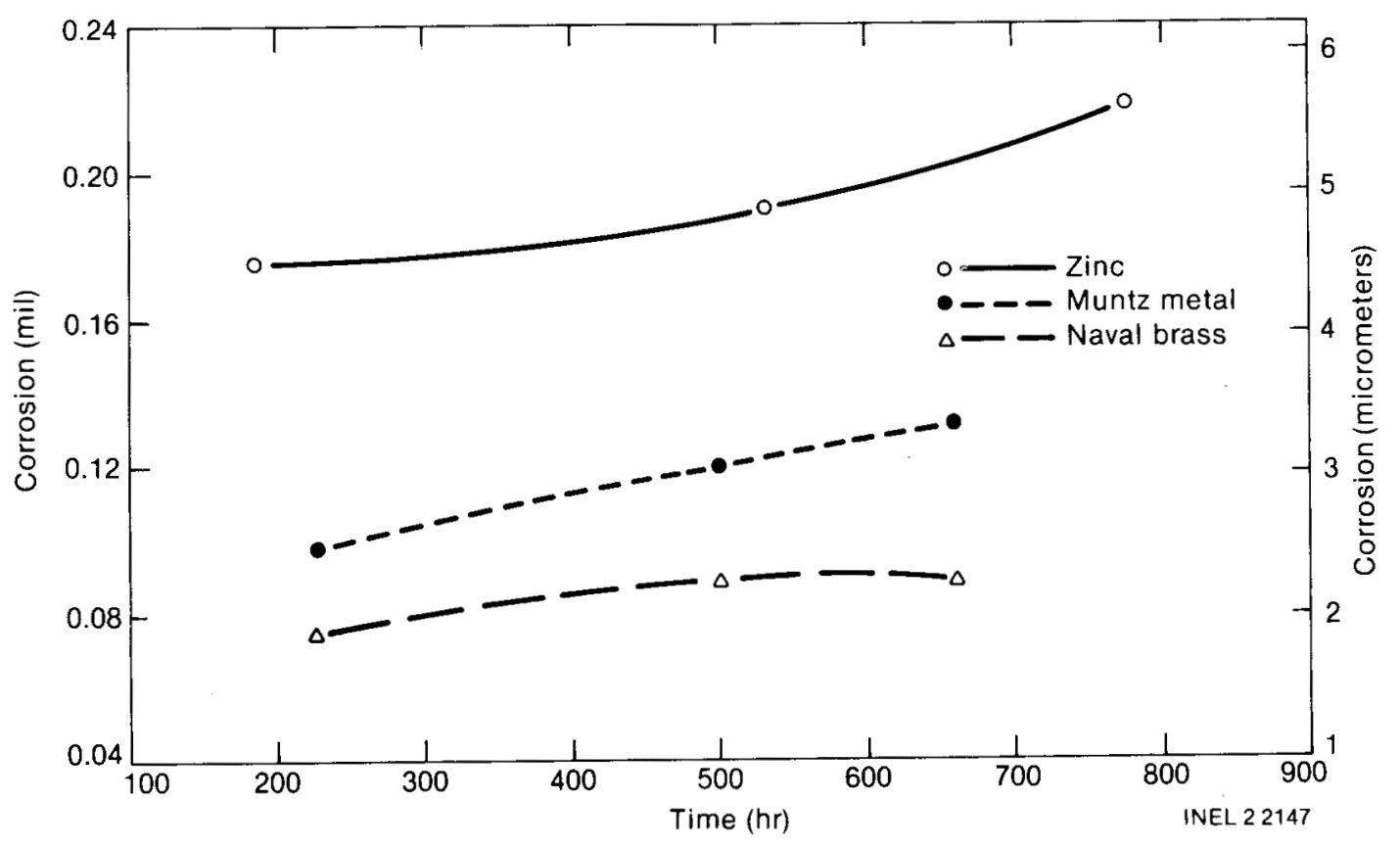

Figure 5. Brasses at 10,000 ppm chloride.

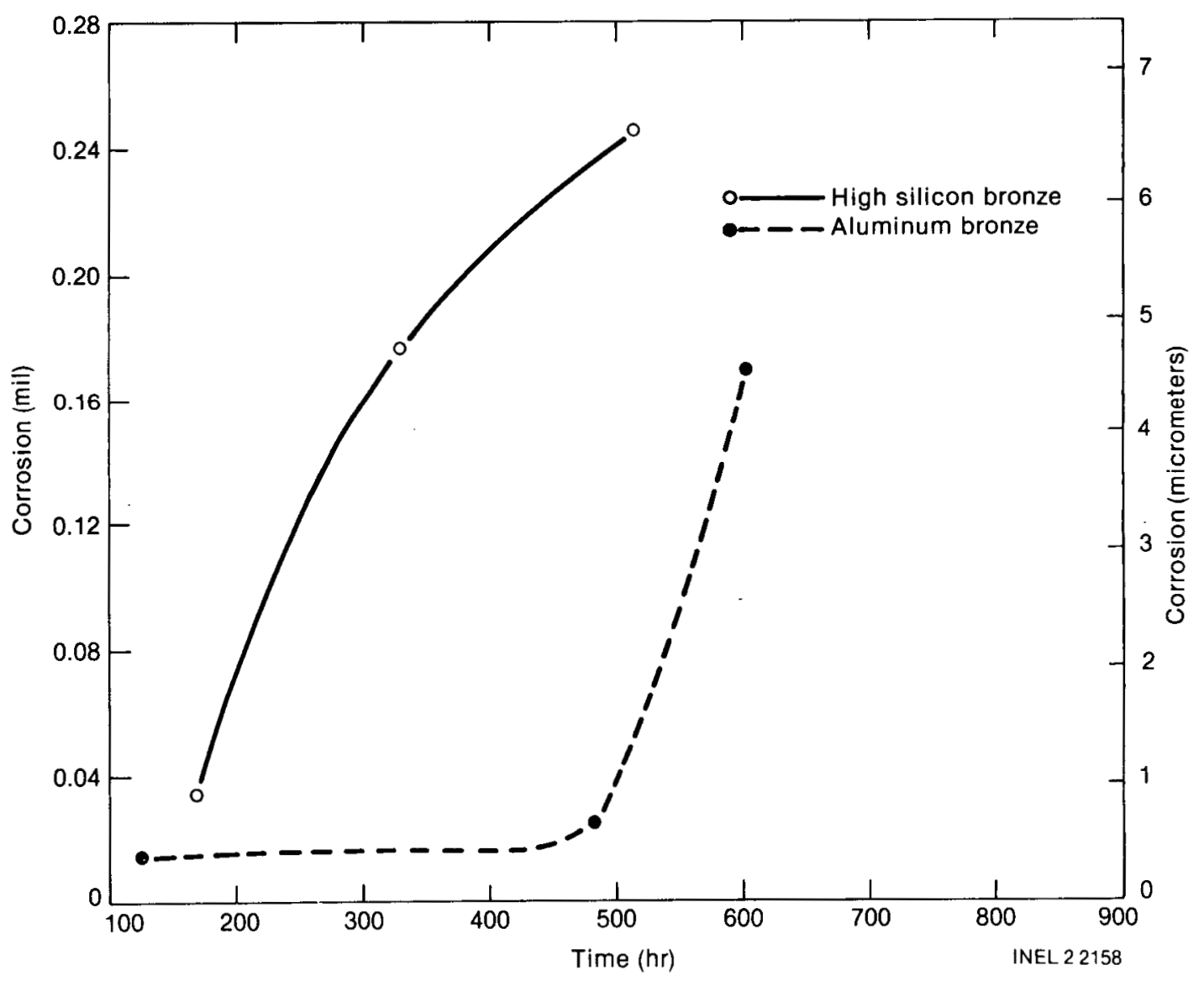

Figure 6. High-silicon bronze and aluminum bronze at 10,000 ppm chloride. 


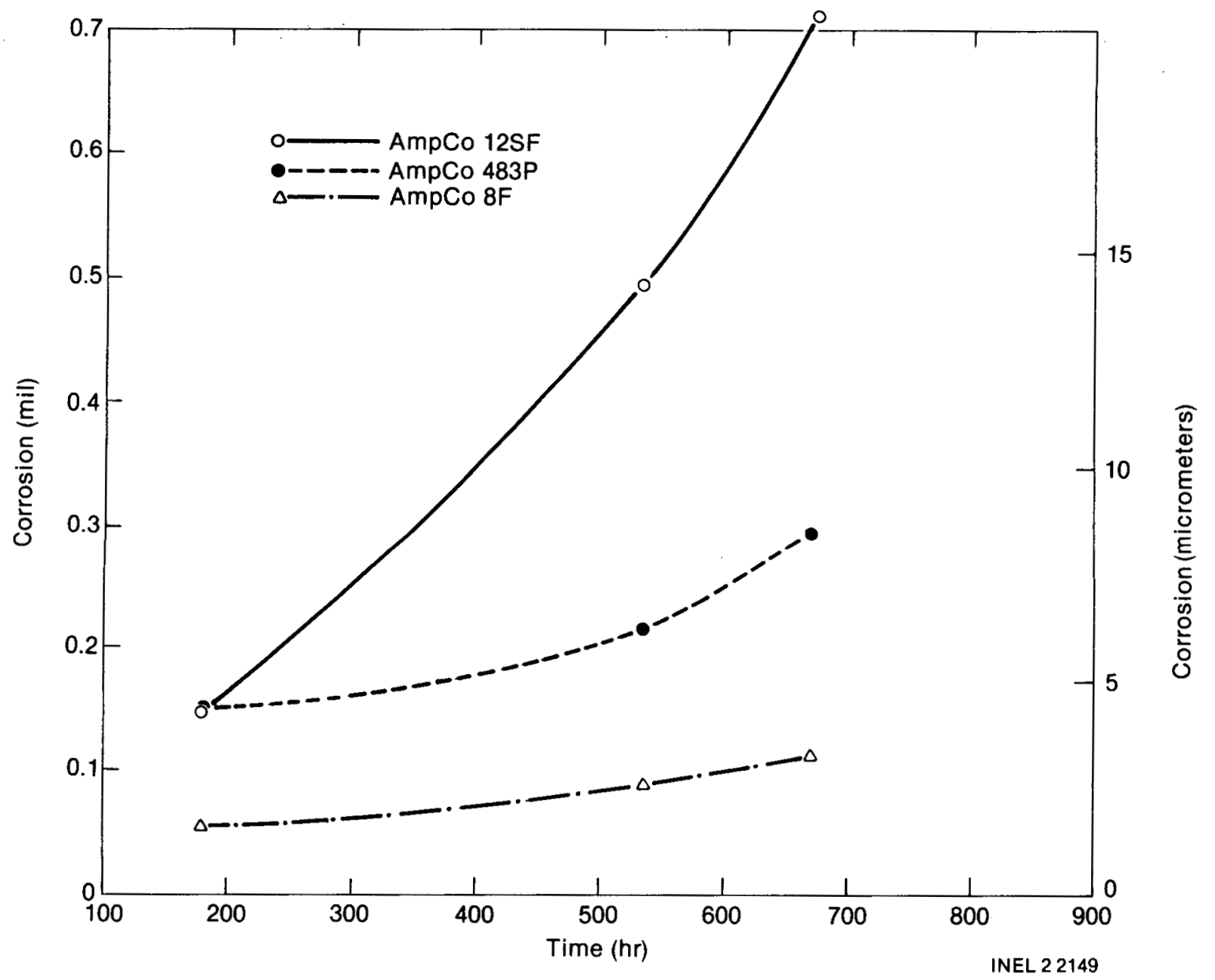

Figure 7. The AmpCo metals at 10,000 chloride. 


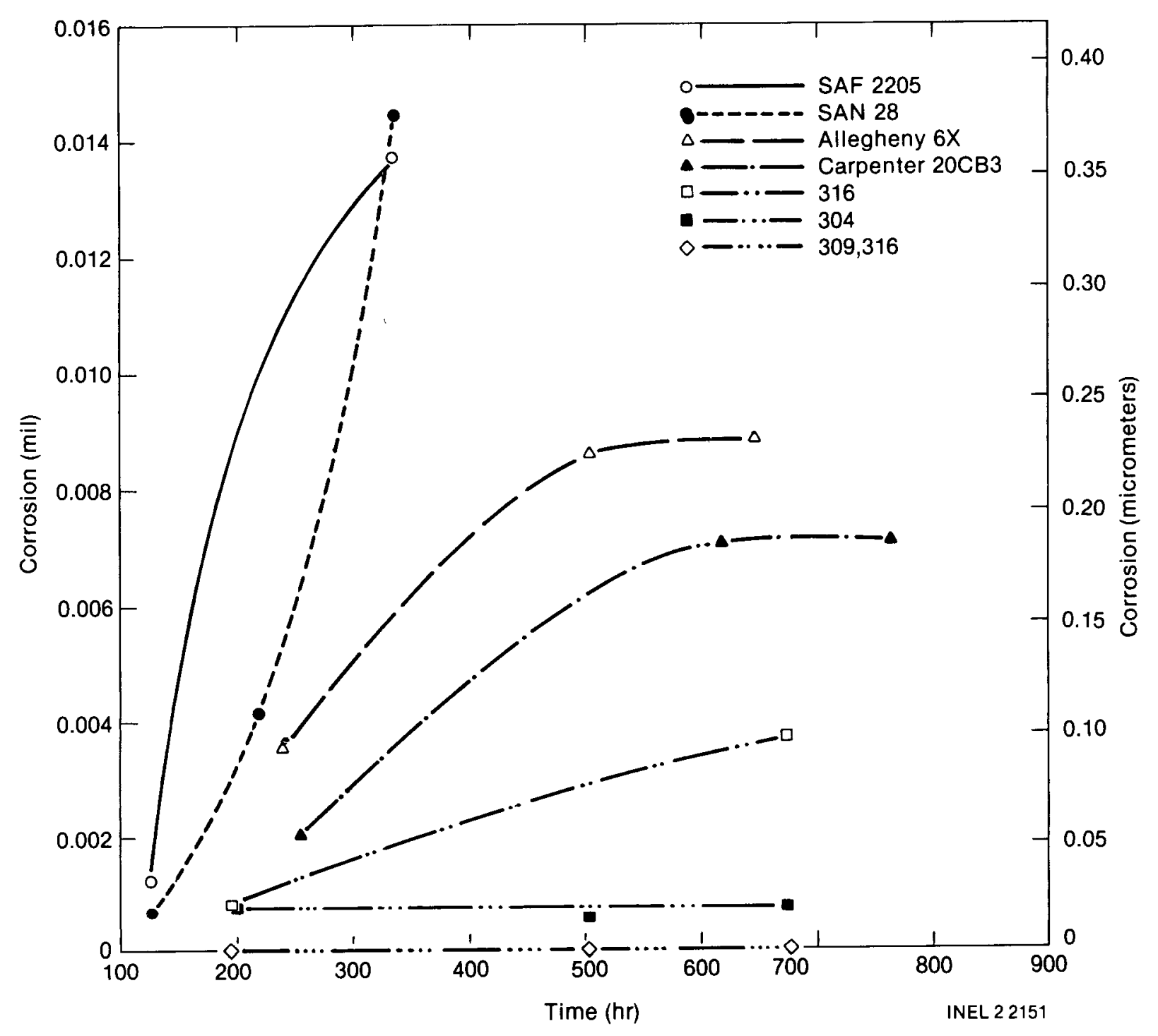

Figure 8. Austenitic stainless steels at 10,000 ppm chloride. 


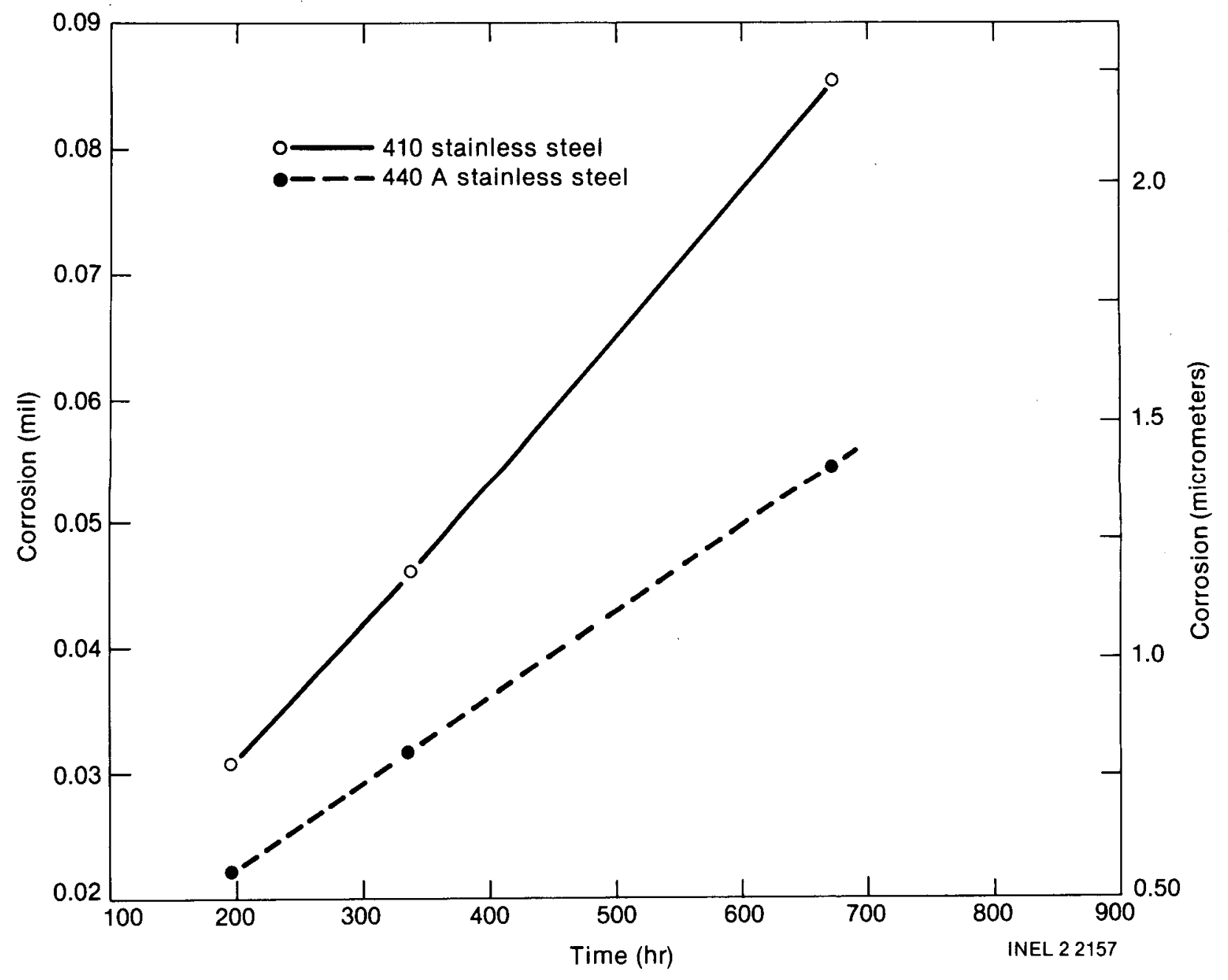

Figure 9. Martensitic stainless steels at 10,000 ppm chloride. 


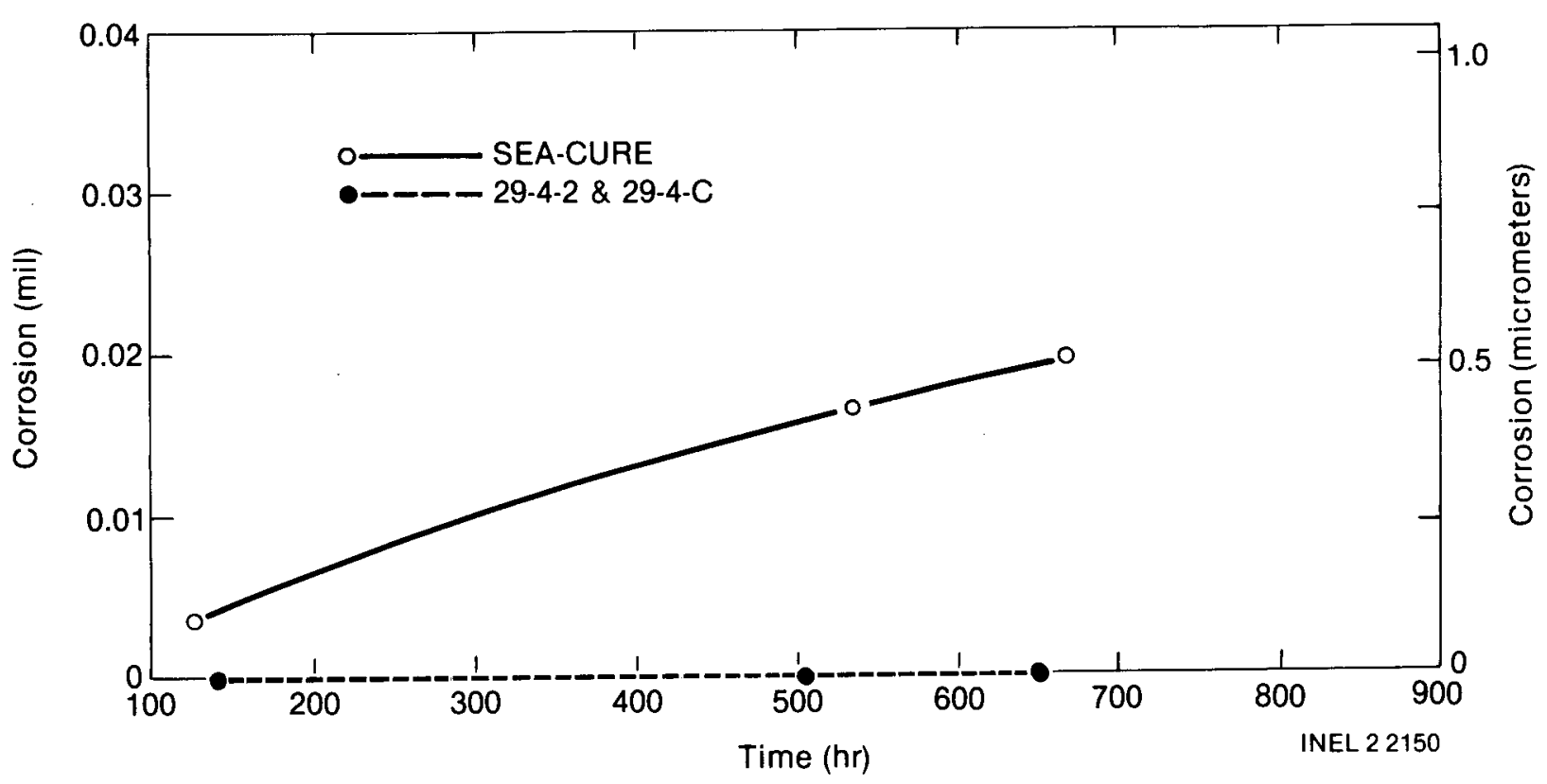

Figure 10. Ferritic stainless steels at $10,000 \mathrm{ppm}$ chloride.

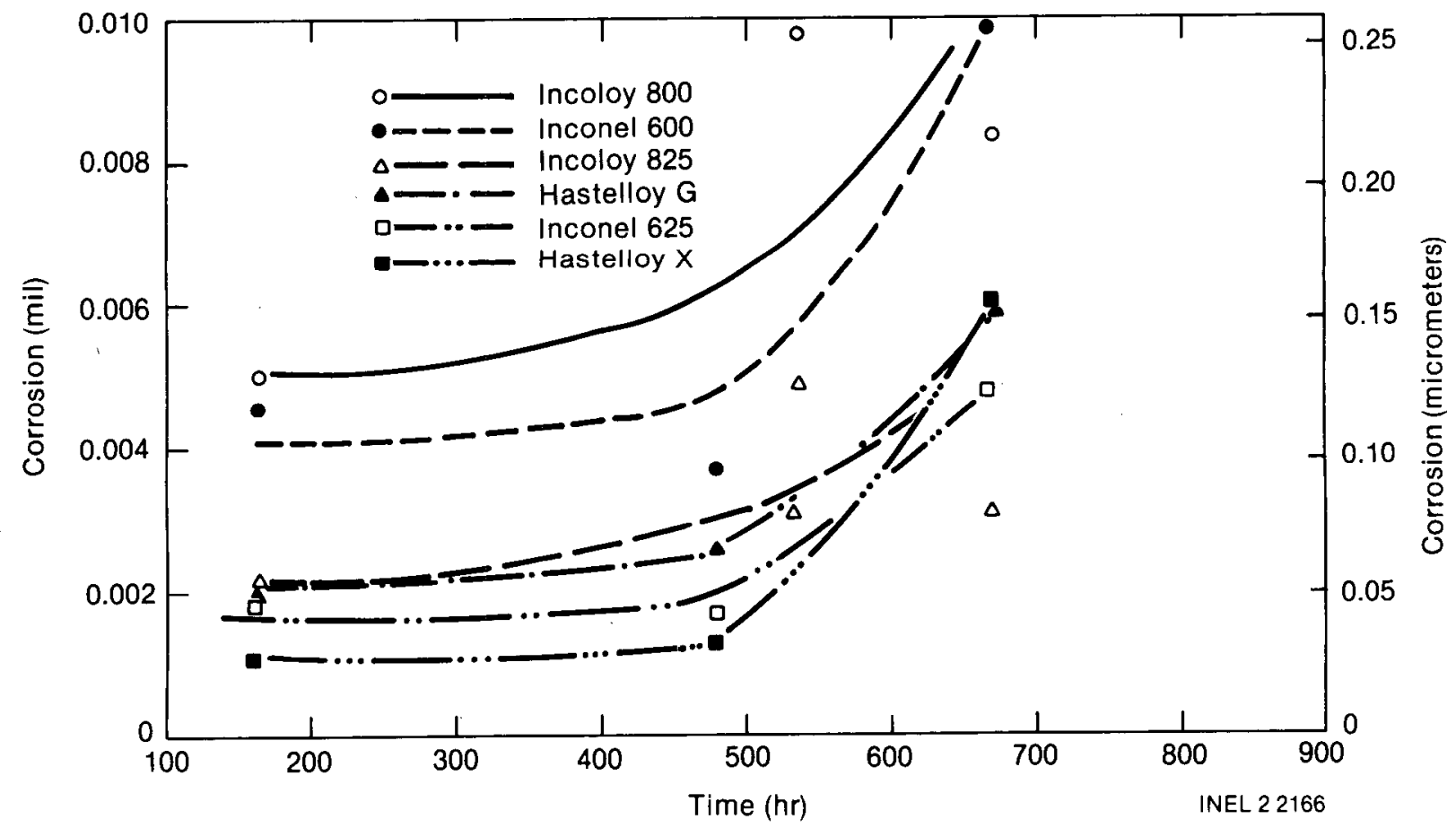

Figure 11. Nickel-base alloys at 10,000 ppm chloride. 


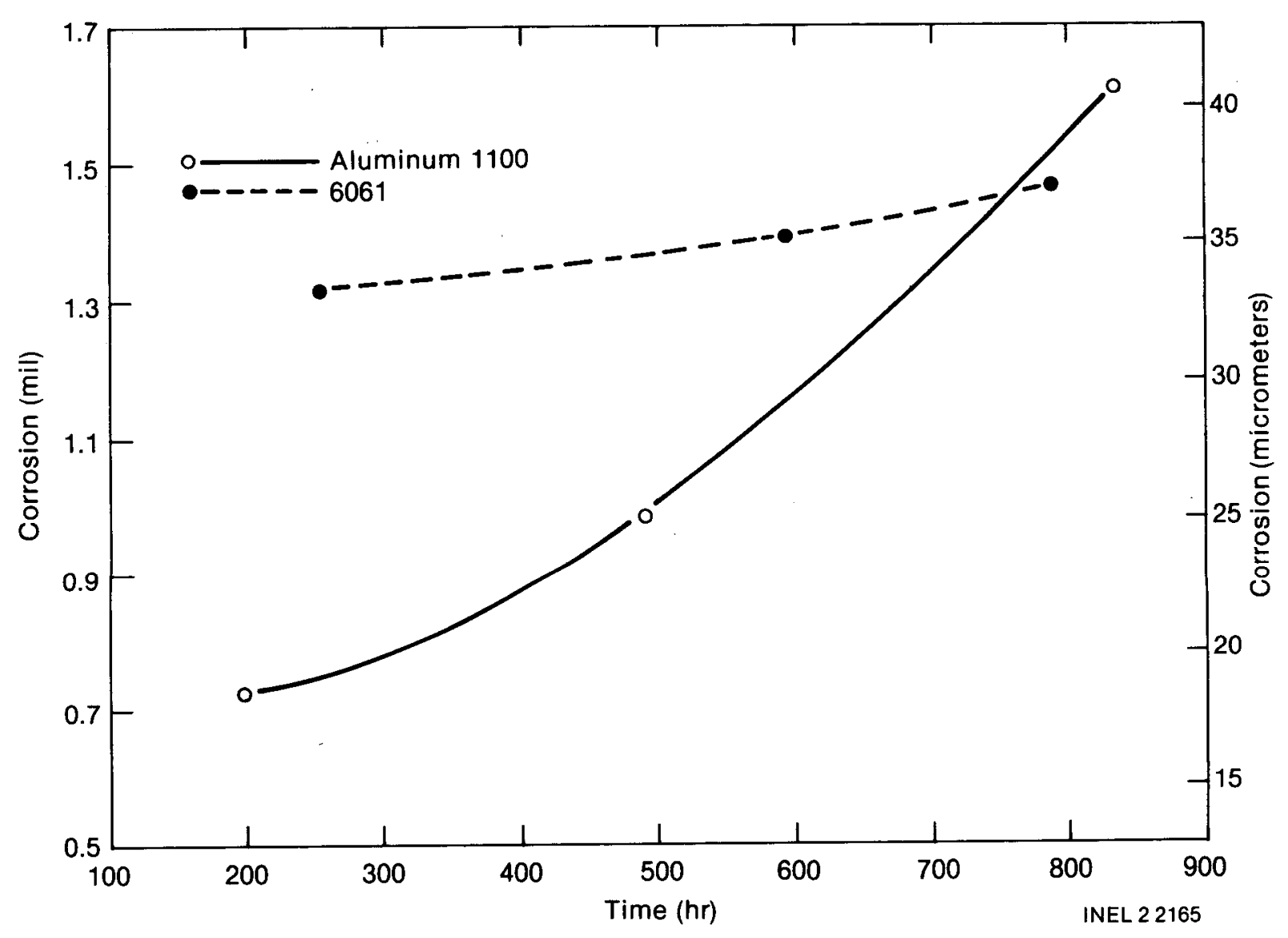

Figure 12. Aluminums at $10,000 \mathrm{ppm}$ chloride. 


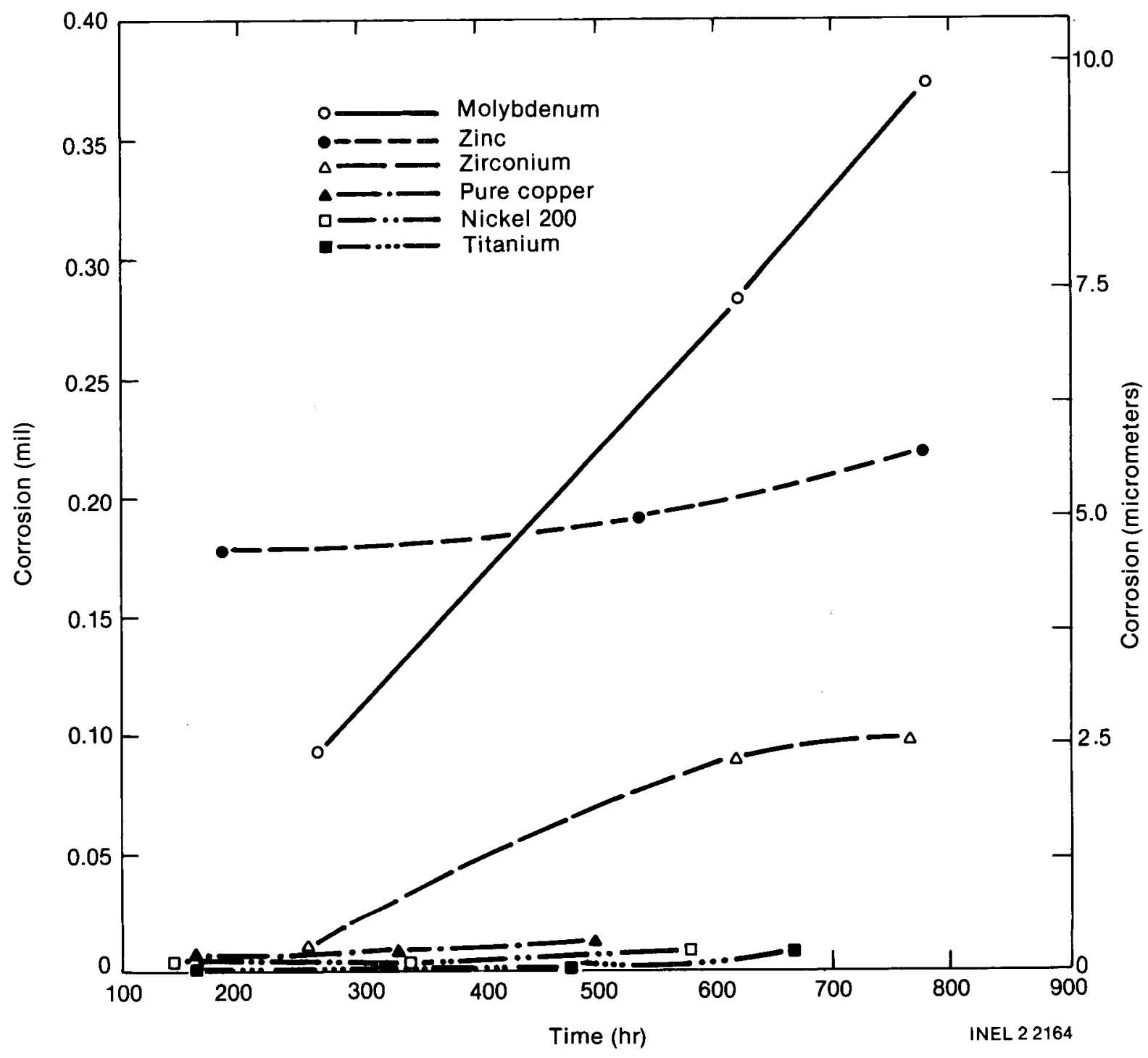

Figure 13. Pure metals at $10,000 \mathrm{ppm}$ chloride. 


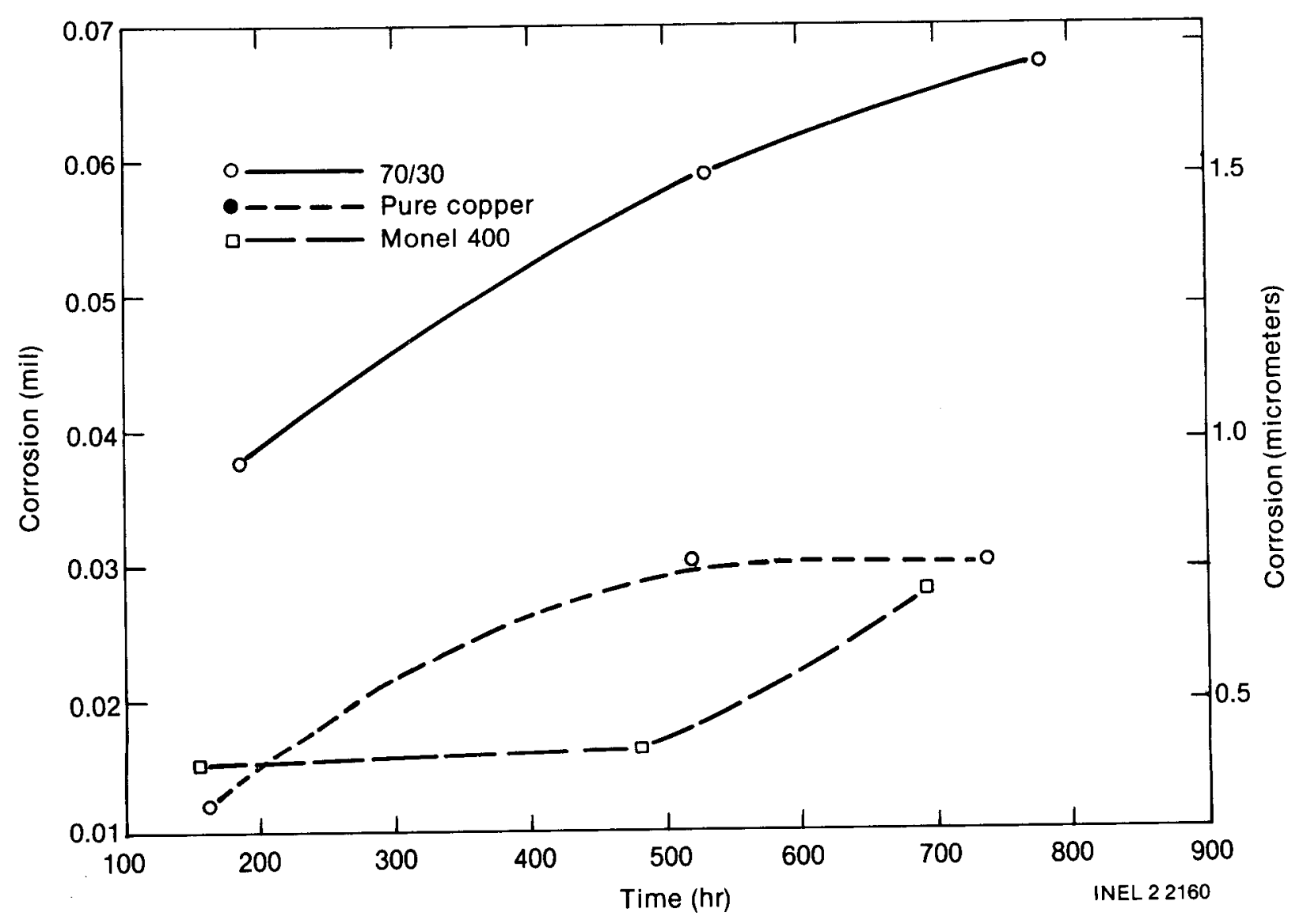

Figure 14. Copper-nickel alloys at 50,000 ppm chloride.

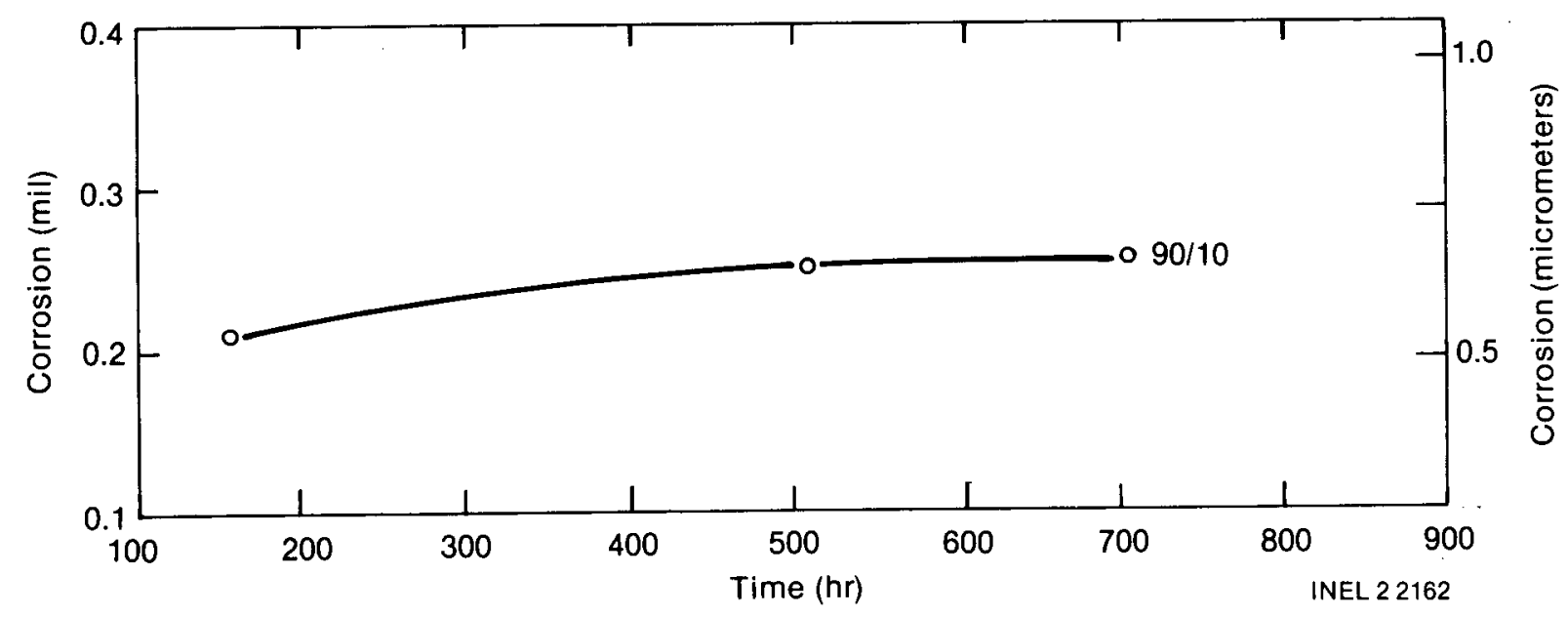

Figure 15. $90 / 10$ alloy at 50,000 ppm chloride. 


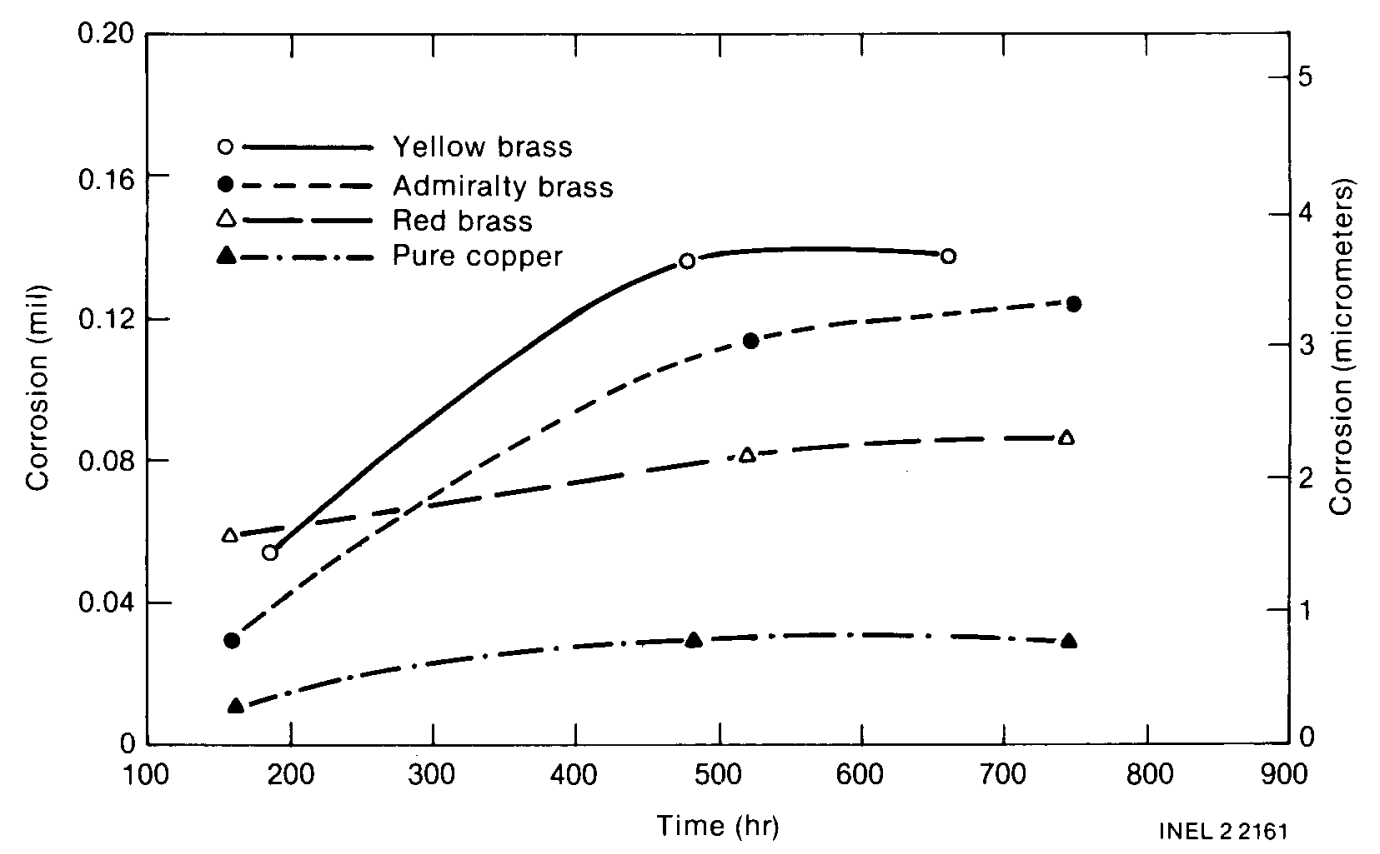

Figure 16. Copper-zinc alloys at 50,000 ppm chloride.

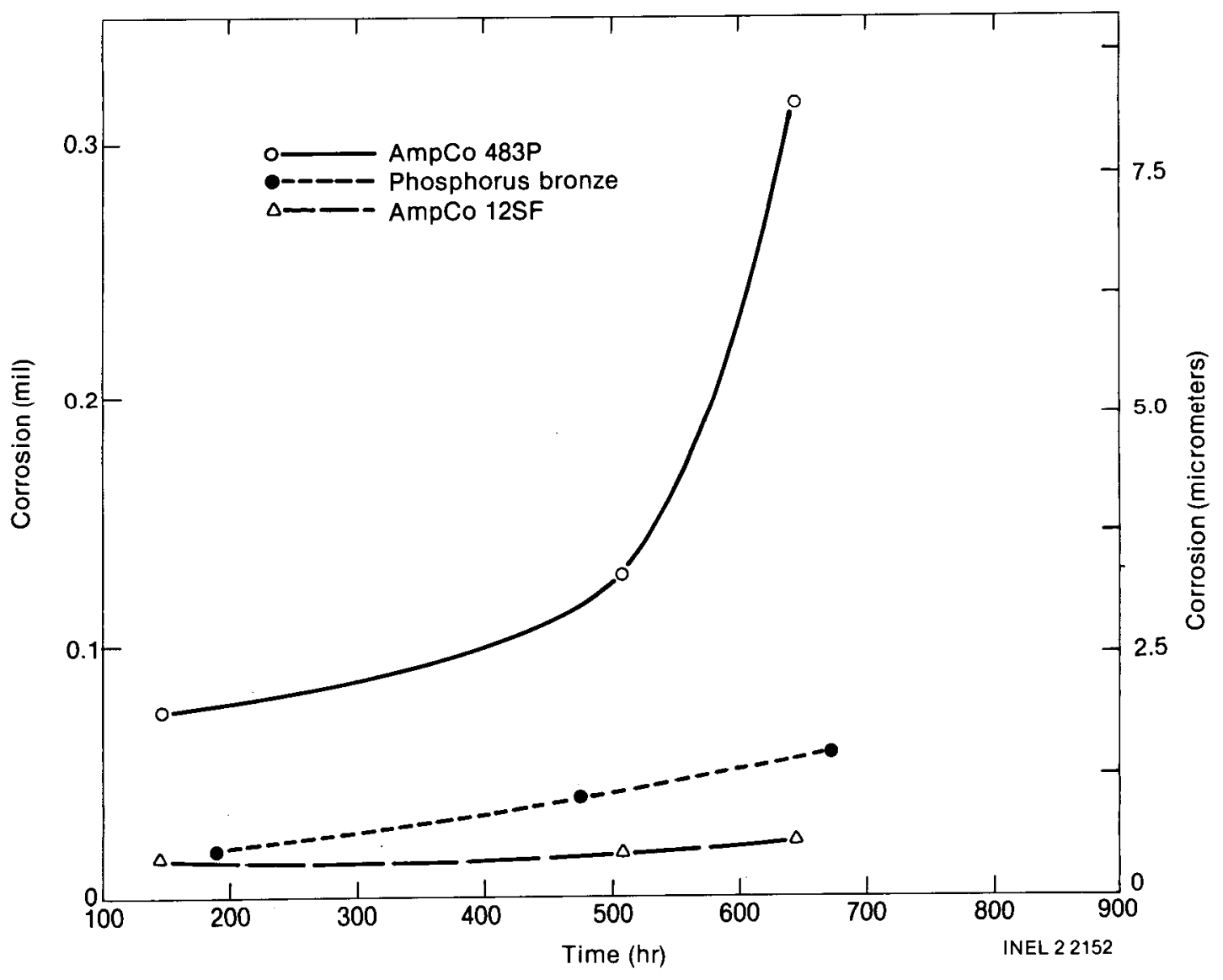

Figure 17. Bronzes at 50,000 ppm chloride. 


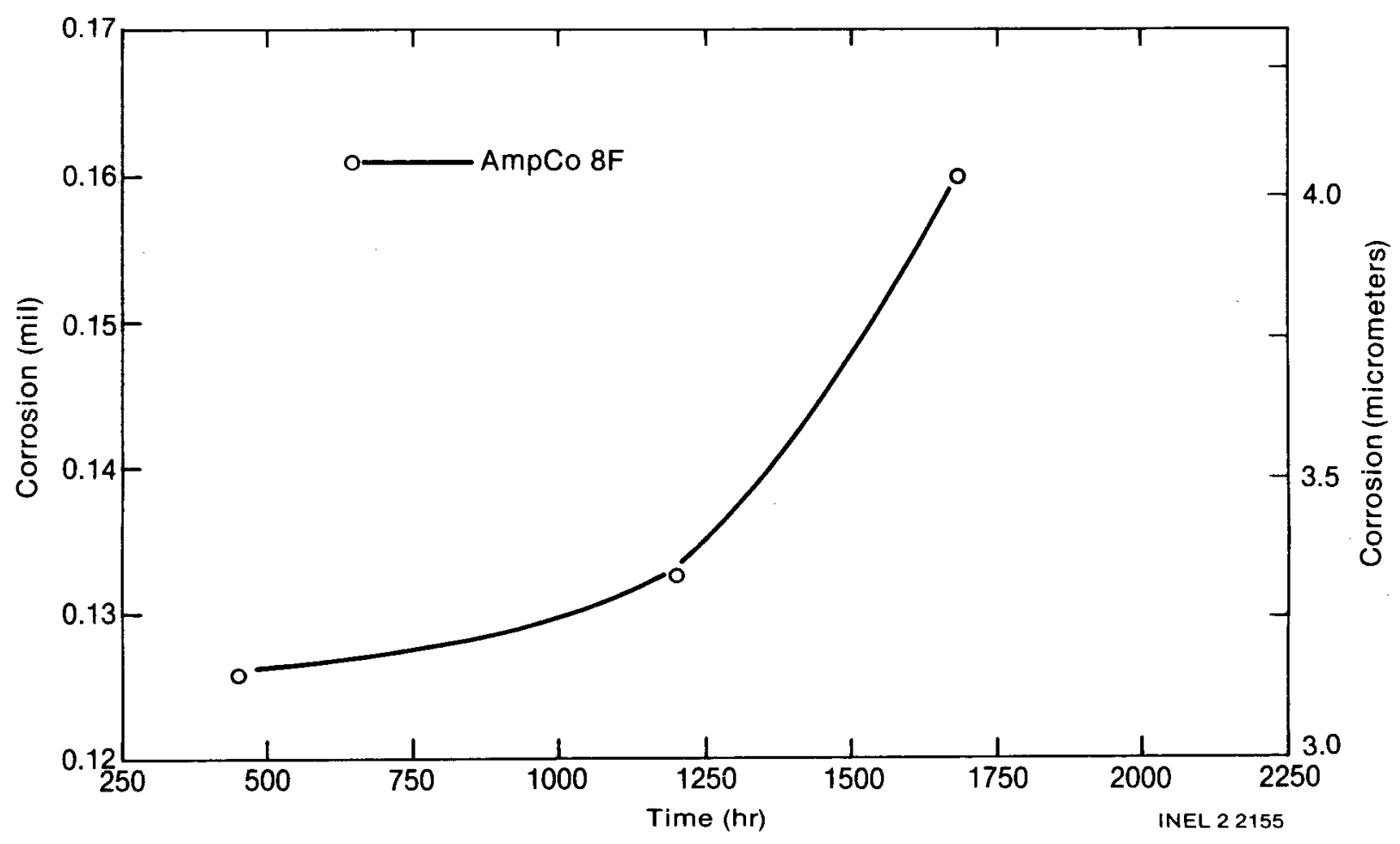

Figure 18. AmpCo 8F at 50,000 ppm chloride.

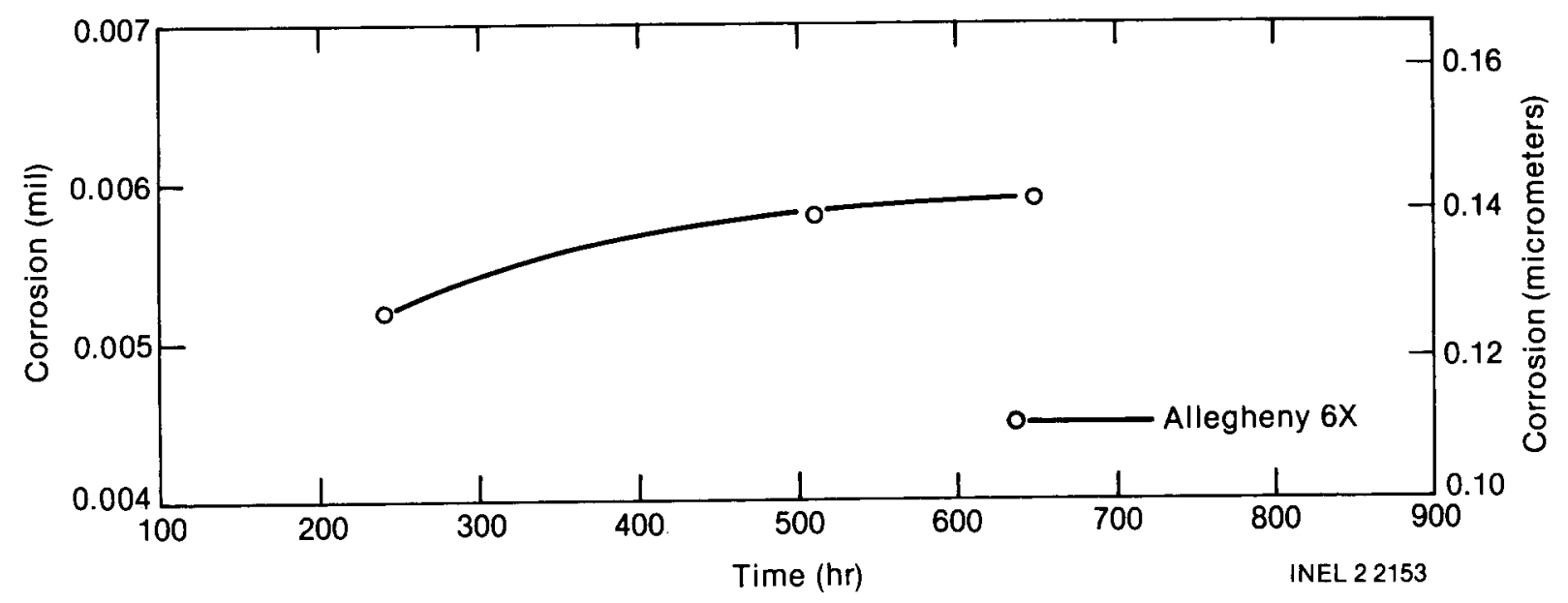

Figure 19. Austenitic stainless steels at 50,000 ppm chloride. 


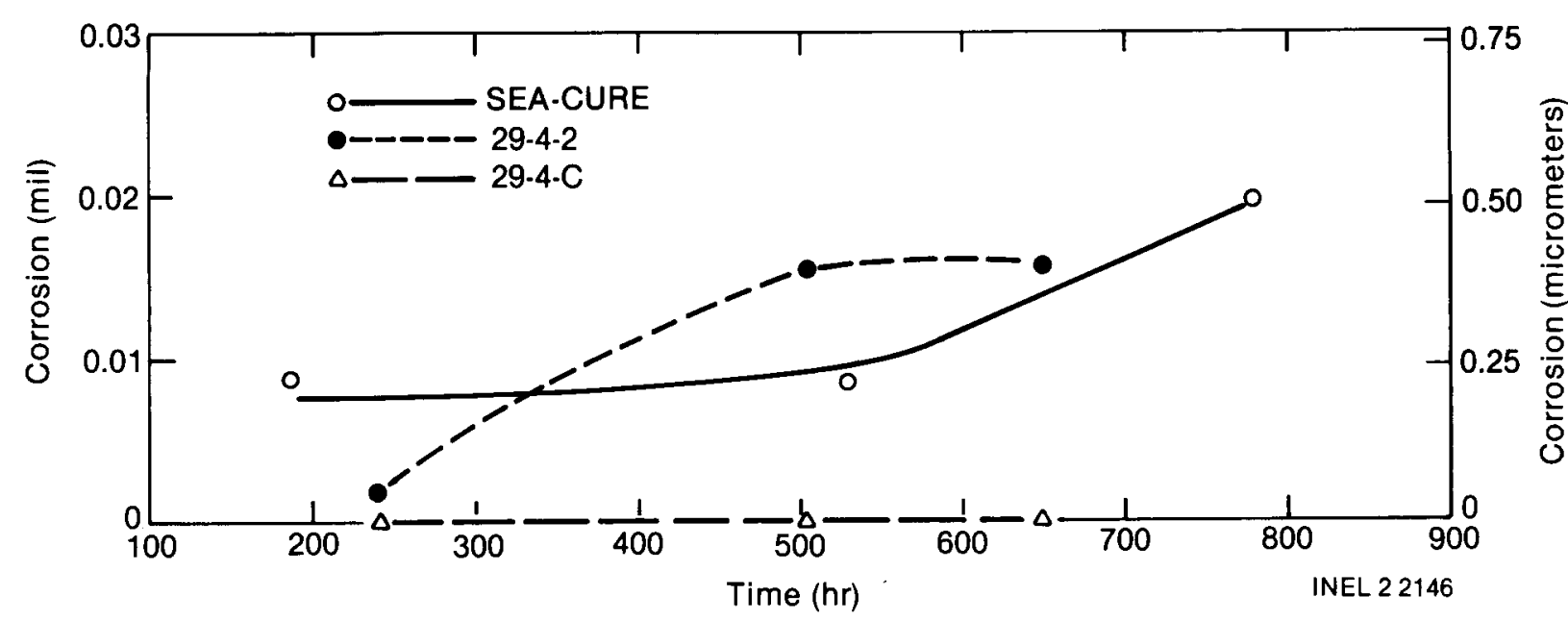

Figure 20. Ferritic stainless steels at 50,000 ppm chloride.

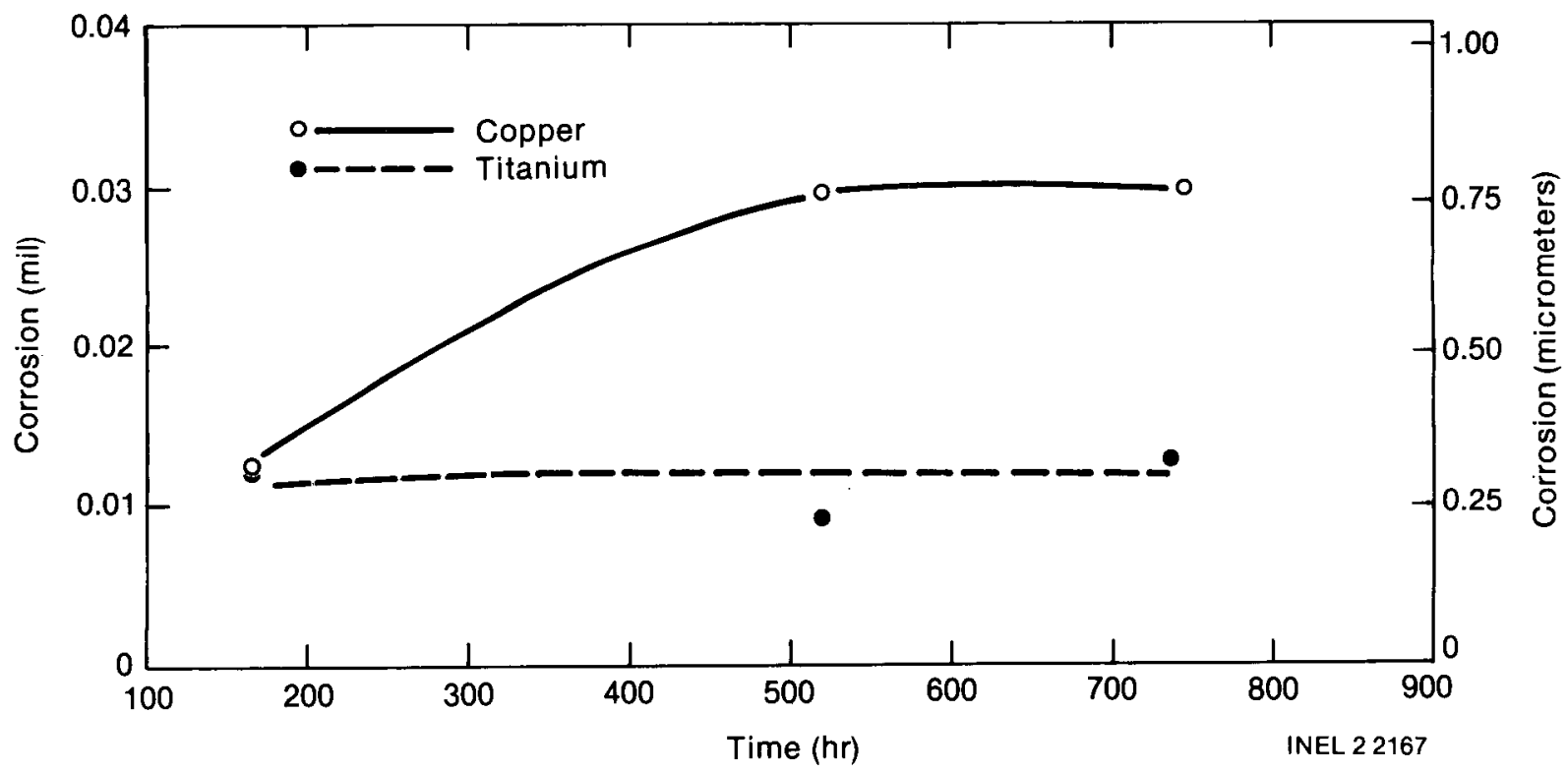

Figure 21. Pure metals at 50,000 ppm chloride. 


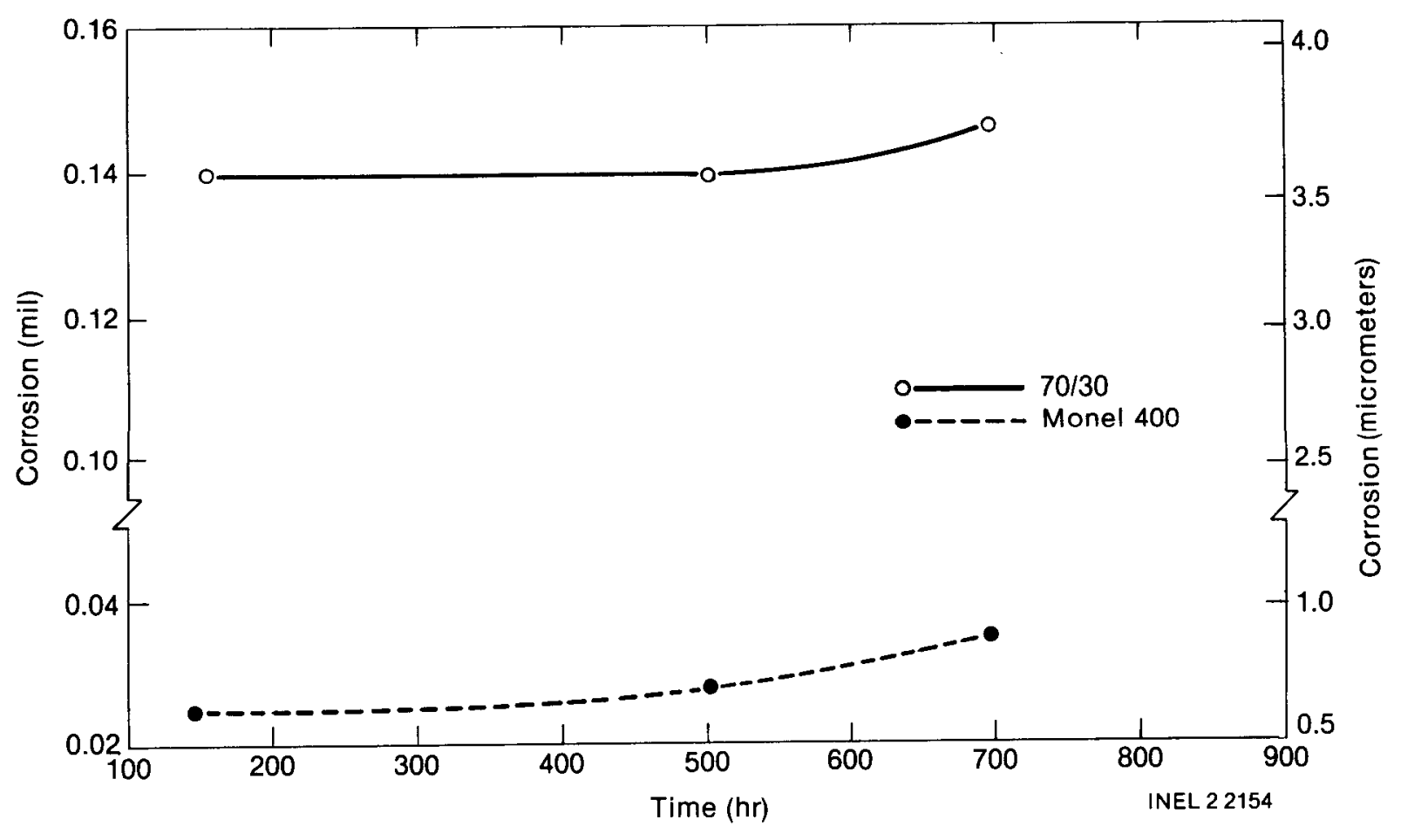

Figure 22. $70 / 30$ alloy and Monel 400 at 100,000 ppm chloride. 
Table 4. Corrosion of metals after corrosion testing for 1 month in the spinner tests

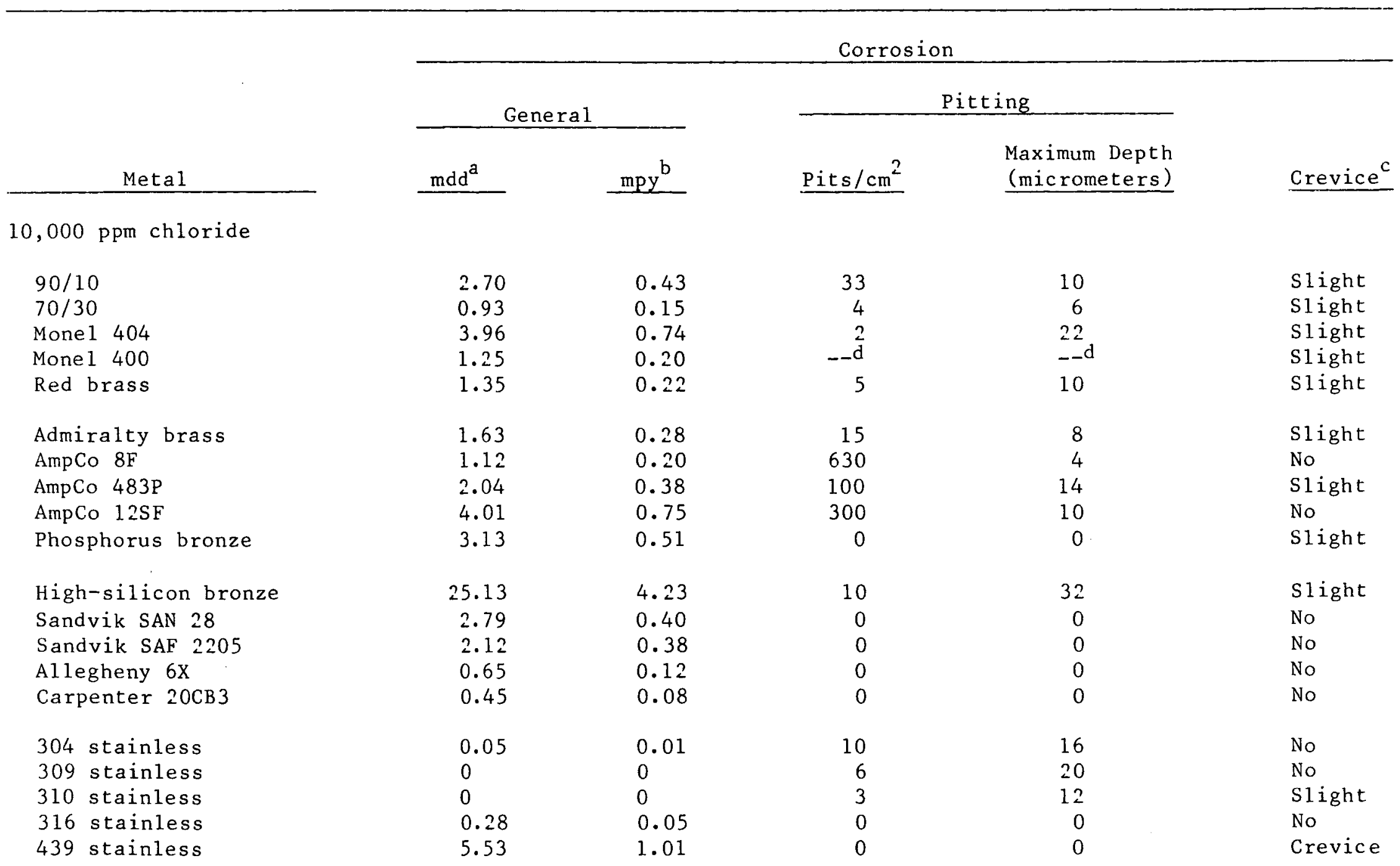


Table 4. (continued)

Corrosion

\begin{tabular}{|c|c|c|c|c|}
\hline \multicolumn{2}{|c|}{ Genera 1} & \multicolumn{2}{|c|}{ Pitting } & \\
\hline $\mathrm{mdd}^{\mathrm{a}}$ & mpy ${ }^{b}$ & Pits $/ \mathrm{cm}^{2}$ & $\begin{array}{l}\text { Maximum Depth } \\
\text { (micrometers) }\end{array}$ & Crevice \\
\hline
\end{tabular}

10,000 ppm chloride (continued)

410 stainless

440A stainless

SEA-CURE

29-4

29-4-2

N

Ferralium 255

Hastelloy $\mathrm{X}$

Haste1loy G

Incoloy 800

Incoloy 825

Inconel 600

Inconel 625

Carbon steel

High-silicon cast iron

$9 \mathrm{Cr}-1$ Mo

Aluminum 1100

Aluminum 6061

Pure copper

Nickel 200

\begin{tabular}{lr}
6.00 & 1.12 \\
5.56 & 1.03 \\
1.37 & 0.26 \\
0 & 0 \\
0 & 0 \\
0 & \multicolumn{1}{l}{} \\
0.27 & 0 \\
0.45 & 0.05 \\
0.45 & 0.08 \\
0.61 & 0.11 \\
& \\
0.23 & 0.04 \\
0.73 & 0.13 \\
0.37 & 0.06 \\
8.97 & 211.86 \\
7.40 & 72.31 \\
& \\
3.30 & 0.60 \\
26.04 & 16.93 \\
0.52 & 16.24 \\
1.80 & 0.29 \\
0.60 & 0.10
\end{tabular}

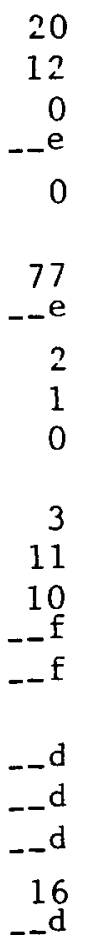

2

28

- 0

0

8
$--\mathrm{e}$

8

10

0

10

14

14

- f

$--d$

$--d$

$--d$

16

Crevice

Slight

No

No

No

No

No

No

No

Slight

No

No

No

Crevice

Crevice

Crevice

Crevice

Crevice

Slight

No 
Table 4. (continued)

\begin{tabular}{|c|c|c|c|c|c|}
\hline \multirow[b]{3}{*}{ Metal } & \multicolumn{5}{|c|}{ Corrosion } \\
\hline & \multicolumn{2}{|c|}{ General } & \multicolumn{2}{|c|}{ Pitting } & \multirow[b]{2}{*}{ Crevice $^{\mathrm{c}}$} \\
\hline & mdd $^{\mathrm{a}}$ & mpy & Pits $/ \mathrm{cm}^{2}$ & $\begin{array}{l}\text { Maximum Depth } \\
\text { (micrometers) }\end{array}$ & \\
\hline \multicolumn{6}{|l|}{$\begin{array}{l}10,000 \text { ppm chloride } \\
\text { (continued) }\end{array}$} \\
\hline Zirconium & 5.07 & 1.12 & 0 & 0 & No \\
\hline Molybdenum & 30.88 & 4.35 & 0 & 0 & No \\
\hline Titanium & 0.30 & 0.10 & 2 & 20 & No \\
\hline Zinc & 12.30 & 2.47 & 90 & 14 & Severe \\
\hline \multicolumn{6}{|l|}{50,000 ppm chloride } \\
\hline $90 / 10$ & 25.55 & 4.11 & 36 & 19 & Slight \\
\hline $70 / 30$ & 4.75 & 0.76 & $--d$ & 18 & Crevice \\
\hline Monel 400 & 2.10 & 0.34 & $--^{e}$ & e & Slight \\
\hline Red brass & 6.27 & 1.03 & 56 & 6 & Slight \\
\hline Admira1ty & 8.67 & 1.46 & 50 & 8 & Slight \\
\hline Ye 11 ow brass & 10.94 & 1.86 & 5 & 6 & No \\
\hline AmpCo $8 \mathrm{~F}$ & 4.79 & 0.83 & 540 & 10 & Crevice \\
\hline AmpCo $483 \mathrm{P}$ & 12.83 & 2.22 & 0 & 0 & No \\
\hline AmpCo $12 \mathrm{SF}$ & 24.84 & $4 \cdot 30$ & 0 & 0 & No \\
\hline Phosphorus bronze & 4.73 & 0.76 & 0 & 0 & Crevice \\
\hline Allegheny $6 \mathrm{x}$ & 0.38 & 0.07 & 0 & 0 & No \\
\hline SEA-CURE & 1.18 & 0.22 & 0 & 0 & No \\
\hline $29-4$ & 0 & 0 & 0 & 0 & No \\
\hline $29-4-2$ & 1.17 & 0.21 & 0 & 0 & No \\
\hline $29-4-C$ & 0 & 0 & 0 & 0 & No \\
\hline
\end{tabular}


Table 4. (continued)

Corrosion

\begin{tabular}{|c|c|c|c|c|c|}
\hline \multirow[b]{2}{*}{ Meta1 } & \multicolumn{2}{|c|}{ General } & \multicolumn{2}{|c|}{ Pitting } & \multirow[b]{2}{*}{ Crevice $^{c}$} \\
\hline & $\mathrm{mdd}^{\mathrm{a}}$ & $\mathrm{mpy}^{\mathrm{b}}$ & Pits $/ \mathrm{cm}^{2}$ & $\begin{array}{l}\text { Maximum Depth } \\
\text { (micrometers) }\end{array}$ & \\
\hline \multicolumn{6}{|l|}{$\begin{array}{l}50,000 \text { ppm chloride } \\
\text { (continued) }\end{array}$} \\
\hline Ferralium 255 & 0.89 & 0.17 & $--e$ & $--e$ & Crevice \\
\hline Pure copper & 2.23 & 0.36 & 130 & 2 & Crevice \\
\hline Nicke 1200 & 0.48 & 0.08 & $--e$ & $--e$ & Slight \\
\hline \multicolumn{6}{|l|}{100,000 ppm chloride } \\
\hline $90 / 10$ & 71.73 & 11.53 & 0 & 0 & No \\
\hline $70 / 30$ & 11.88 & 1.91 & 1 & 20 & Slight \\
\hline Mone 1400 & 2.72 & 0.44 & 0 & 0 & No \\
\hline Red brass & 222.86 & 36.6 & 0 & 0 & Slight \\
\hline Admiralty brass & 100.9 & 17.0 & 0 & 0 & Slight \\
\hline Yellow brass & 117.3 & 19.9 & 0 & 0 & Slight \\
\hline Phosphorus bronze & 36.9 & 6.05 & $--e$ & $--^{e}$ & No \\
\hline Allegheny $6 \mathrm{X}$ & 0 & 0 & 0 & 0 & No \\
\hline SEA-CURE & 0.38 & 0.01 & 0 & 0 & No \\
\hline $29-4$ & 2.09 & 0.38 & $--e$ & $--\mathrm{e}$ & Slight \\
\hline $29-4-2$ & 0 & 0 & 0 & 0 & No \\
\hline $29-4-C$ & 0 & 0 & 0 & 0 & No \\
\hline Ferralium & 1.22 & 0.23 & $--^{e}$ & $-e^{e}$ & Crevice \\
\hline Pure copper & 120.37 & 19.41 & $--^{e}$ & $--e$ & No \\
\hline Nickel 200 & 0.87 & 0.14 & $--e$ & $--^{e}$ & Slight \\
\hline
\end{tabular}


Table 4. (continued)

Corrosion

\begin{tabular}{|c|c|c|c|c|c|}
\hline \multirow[b]{2}{*}{ Meta1 } & \multicolumn{2}{|c|}{ Genera 1} & \multicolumn{2}{|c|}{ Pitting } & \multirow[b]{2}{*}{ Crevice $^{\mathrm{c}}$} \\
\hline & $\mathrm{mdd}^{\mathrm{a}}$ & $\mathrm{mpy}^{\mathrm{b}}$ & Pits $/ \mathrm{cm}^{2}$ & $\begin{array}{l}\text { Maximum Depth } \\
\text { (micrometers) }\end{array}$ & \\
\hline \multicolumn{6}{|c|}{200,000 ppm chloride } \\
\hline Mone 1400 & 1.24 & 0.20 & - - $^{2}$ & $--e$ & slight \\
\hline Allegheny $6 \mathrm{X}$ & 0.06 & 0.01 & $\ldots e$ & --e & No \\
\hline SEA-CURE & 0 & 0 & 0 & 0 & No \\
\hline $29-4-2$ & 0.27 & 0.005 & -_e & -_e & No \\
\hline Nicke 1200 & 1.61 & 0.26 & $\ldots e$ & --e & Crevice \\
\hline
\end{tabular}

a. Milligrams per square decimeter per day.

b. Mils per year.

c. No--No apparent crevice corrosion.

Slight--Visible line at interface of coupon with teflon washer.

Crevice--Noticable corrosion at interface.

Severe--Coupon is severely corroded at interface.

d. Original surface condition made measurement of pit depth or density difficult.

e. Pit depth or number of pits was not determined.

f. General corrosion was too great for pit depth or density determination. 
Table 5. General corrosion of metals with time during corrosion testing in the spinner test apparatus

\begin{tabular}{|c|c|c|c|}
\hline \multirow[b]{2}{*}{ Metal } & \multirow[b]{2}{*}{$\begin{array}{l}\text { Time } \\
(\mathrm{hr})\end{array}$} & \multicolumn{2}{|c|}{ Corrosion } \\
\hline & & mdd & mpy \\
\hline \multicolumn{4}{|l|}{$10,000 \mathrm{ppm}$ chloride } \\
\hline \multicolumn{4}{|c|}{ Copper-nickel alloys } \\
\hline \multirow{3}{*}{$90 / 10$} & 164 & 1.68 & 0.27 \\
\hline & $\begin{array}{l}333 \\
500\end{array}$ & $\begin{array}{l}2.80 \\
2.67\end{array}$ & $\begin{array}{l}0.45 \\
0.43\end{array}$ \\
\hline & 167 & 4.07 & 0.66 \\
\hline \multirow{4}{*}{$70 / 30$} & 164 & 0.75 & 0.12 \\
\hline & 333 & 0.74 & 0.12 \\
\hline & 500 & 0.93 & 0.15 \\
\hline & 167 & 1.53 & 0.24 \\
\hline \multirow[t]{5}{*}{ Mone 1404} & 168 & 6.45 & 1.04 \\
\hline & 330 & 5.37 & 0.87 \\
\hline & 512 & 3.96 & 0.64 \\
\hline & 497.5 & 1.72 & 0.28 \\
\hline & 153.5 & 7.57 & 1.22 \\
\hline \multirow[t]{5}{*}{ Mone 1400} & 165 & 3.32 & 0.54 \\
\hline & 520 & 1.91 & 0.31 \\
\hline & 737 & 1.23 & 0.20 \\
\hline & 524 & 2.09 & 0.34 \\
\hline & 169 & 1.78 & 0.29 \\
\hline \multicolumn{4}{|l|}{ Copper-zinc alloys } \\
\hline \multirow[t]{4}{*}{ Red brass } & 143 & 2.10 & 0.35 \\
\hline & 336 & 2.22 & 0.36 \\
\hline & 578.5 & 1.35 & 0.22 \\
\hline & 210.5 & 2.38 & 0.39 \\
\hline \multirow[t]{4}{*}{ Admiralty brass } & 143 & 1.45 & 0.24 \\
\hline & 336 & 2.26 & 0.38 \\
\hline & 578.5 & 1.63 & 0.28 \\
\hline & 210.5 & 1.77 & 0.30 \\
\hline \multirow[t]{4}{*}{ Yellow brass } & 213.5 & 0.78 & 0.14 \\
\hline & 528.5 & 0.11 & 0.02 \\
\hline & 699.5 & 3.65 & 0.66 \\
\hline & 171.0 & 3.89 & 0.70 \\
\hline
\end{tabular}


Table 5. (continued)

\begin{tabular}{|c|c|c|c|}
\hline \multirow[b]{2}{*}{ Meta 1} & \multirow[b]{2}{*}{$\begin{array}{l}\text { Time } \\
(\mathrm{hr})\end{array}$} & \multicolumn{2}{|c|}{ Corrosion } \\
\hline & & mdd & mpy \\
\hline \multicolumn{4}{|l|}{$\begin{array}{l}10,000 \text { ppm chloride } \\
\text { (continued) }\end{array}$} \\
\hline \multicolumn{4}{|l|}{$\begin{array}{l}\text { Copper-zinc alloys } \\
\text { (continued) }\end{array}$} \\
\hline \multirow[t]{5}{*}{ Munt $z$ metal } & 227 & 22.35 & 3.83 \\
\hline & 489.5 & 12.36 & 2.12 \\
\hline & 658.5 & 10.29 & 1.76 \\
\hline & 411.5 & 11.06 & 1.89 \\
\hline & 140 & 5.66 & 0.97 \\
\hline \multirow[t]{5}{*}{ Naval brass } & 227 & 16.91 & 2.89 \\
\hline & 489.5 & 9.13 & 1.56 \\
\hline & 658.5 & 6.91 & 1.18 \\
\hline & 411.5 & 1.84 & 0.31 \\
\hline & 140 & 2.71 & 0.46 \\
\hline \multicolumn{4}{|l|}{ Bronzes } \\
\hline \multirow[t]{4}{*}{ Aluminum bronze } & 124.5 & 5.64 & 1.03 \\
\hline & 483.5 & 2.44 & 0.44 \\
\hline & 603.5 & 13.53 & 2.46 \\
\hline & 120.0 & 75.21 & 13.70 \\
\hline \multirow[t]{5}{*}{ AmpCo $8 \mathrm{~F}$} & 168 & 1.59 & 0.29 \\
\hline & 533.5 & 0.79 & 0.14 \\
\hline & 671 & 0.81 & 0.15 \\
\hline & 503 & 1.12 & 0.20 \\
\hline & 139.5 & 2.53 & 0.46 \\
\hline \multirow[t]{5}{*}{ AmpCo $483 \mathrm{P}$} & 168 & 4.20 & 0.79 \\
\hline & 533.5 & 1.89 & 0.35 \\
\hline & 671 & 2.04 & 0.38 \\
\hline & 503 & 0.88 & 0.17 \\
\hline & 139.5 & 2.43 & 0.46 \\
\hline \multirow[t]{5}{*}{ AmpCo $12 S F$} & 168 & 4.11 & 0.77 \\
\hline & 533.5 & 4.31 & 0.81 \\
\hline & 671 & 5.02 & 0.94 \\
\hline & 503 & 4.01 & 0.75 \\
\hline & 139.5 & 3.44 & 0.65 \\
\hline
\end{tabular}


Table 5. (continued)

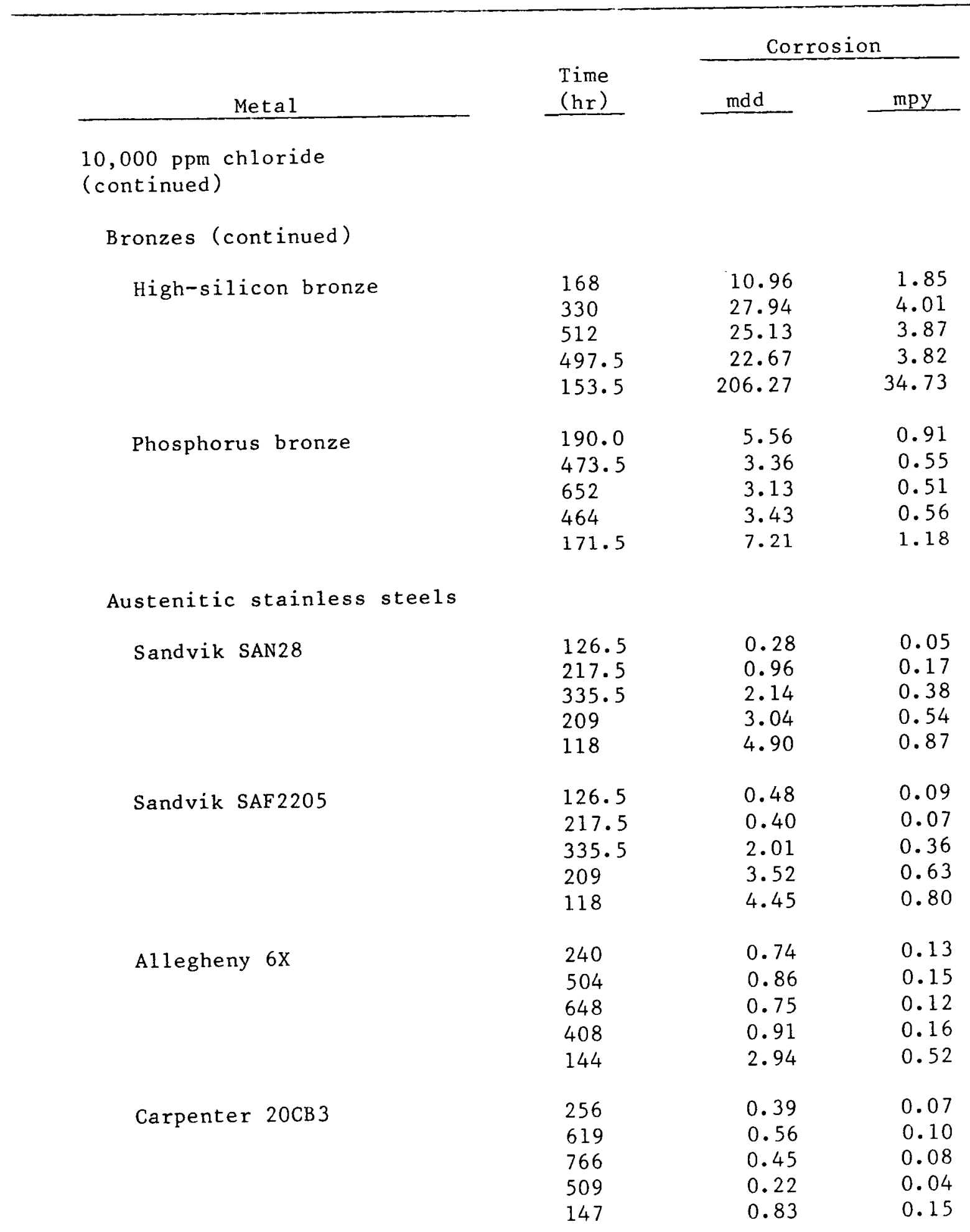


Table 5. (continued)

\begin{tabular}{|c|c|c|c|}
\hline \multirow[b]{2}{*}{ Metal } & \multirow[b]{2}{*}{$\begin{array}{l}\text { Time } \\
(\mathrm{hr})\end{array}$} & \multicolumn{2}{|c|}{ Corrosion } \\
\hline & & mdd & mpy \\
\hline \multicolumn{4}{|l|}{$\begin{array}{l}10,000 \mathrm{ppm} \text { chloride } \\
\text { (continued) }\end{array}$} \\
\hline \multicolumn{4}{|l|}{$\begin{array}{l}\text { Austenitic stainless steels } \\
\text { (continued) }\end{array}$} \\
\hline \multirow[t]{5}{*}{304} & 193.5 & 0.24 & 0.04 \\
\hline & 503 & 0.05 & 0.01 \\
\hline & 671 & 0.05 & 0.01 \\
\hline & 473.5 & 0.07 & 0.02 \\
\hline & 167 & 0.14 & 0.03 \\
\hline \multirow[t]{5}{*}{309} & 193.5 & 0 & 0 \\
\hline & 504 & 0 & 0 \\
\hline & 671 & 0 & 0 \\
\hline & 478.5 & 0 & 0 \\
\hline & 167 & 0 & 0 \\
\hline \multirow[t]{4}{*}{310} & 193.5 & 0 & 0 \\
\hline & 671 & 0 & 0 \\
\hline & 671 & 0 & 0 \\
\hline & 478.5 & 0 & 0 \\
\hline \multirow[t]{4}{*}{316} & 193.5 & 0.23 & 0.04 \\
\hline & 671 & 0.28 & 0.05 \\
\hline & 671 & 0.28 & 0.05 \\
\hline & 478.5 & 0 & 0 \\
\hline \multirow[t]{5}{*}{439} & 146 & 6.68 & 1.21 \\
\hline & 503 & 5.97 & 1.09 \\
\hline & 695 & 5.53 & 1.01 \\
\hline & 551 & 6.40 & 1.16 \\
\hline & 192 & 9.40 & 1.71 \\
\hline \multicolumn{4}{|l|}{ Martensitic stainless steels } \\
\hline \multirow[t]{5}{*}{410} & 193.5 & 6.41 & 1.23 \\
\hline & 336 & 5.73 & 1.10 \\
\hline & 671 & 6.00 & 1.12 \\
\hline & 478.5 & 2.44 & 0.49 \\
\hline & 167 & 7.43 & 1.43 \\
\hline \multirow[t]{5}{*}{$440 \mathrm{~A}$} & 193.5 & 12.72 & 2.36 \\
\hline & 336 & 10.54 & 1.95 \\
\hline & 671 & 5.56 & 1.03 \\
\hline & 478.5 & 12.74 & 2.36 \\
\hline & 167 & 40.90 & 7.58 \\
\hline
\end{tabular}


Table 5. (continued)

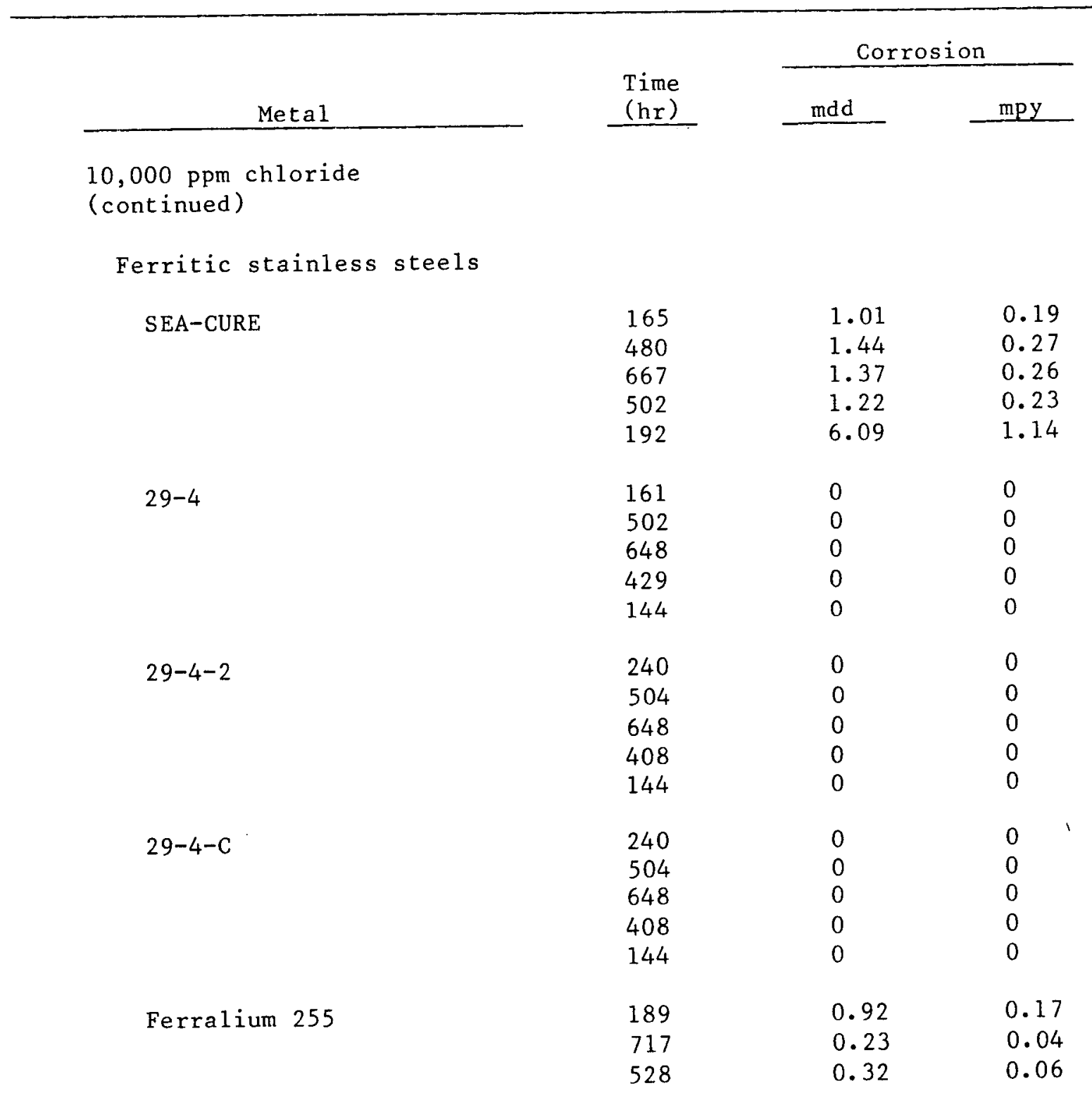

$\begin{array}{llll}\text { Nicke1-based alloys } & & & \\ \text { Hastelloy X } & 165 & 0.34 & 0.06 \\ & 486 & 0.14 & 0.02 \\ & 667 & 0.45 & 0.08 \\ & 502 & 0.44 & 0.08 \\ \text { Hastelloy G } & 192 & 0.52 & 0.09 \\ & 165 & 0.67 & 0.12 \\ & 486 & 0.28 & 0.05 \\ & 667 & 0.45 & 0.08 \\ & 503 & 0.35 & 0.06 \\ & 192 & 0.58 & 0.10\end{array}$


Table 5. (continued)

\begin{tabular}{|c|c|c|c|}
\hline \multirow[b]{2}{*}{ Meta1 } & \multirow{2}{*}{$\begin{array}{l}\text { Time } \\
(\mathrm{hr})\end{array}$} & \multicolumn{2}{|c|}{ Corrosion } \\
\hline & & mdd & mpy \\
\hline \multicolumn{4}{|l|}{$\begin{array}{l}10,000 \text { ppm chloride } \\
\text { (continued) }\end{array}$} \\
\hline \multicolumn{4}{|l|}{$\begin{array}{l}\text { Nickel-based alloys } \\
\text { (continued) }\end{array}$} \\
\hline Incoloy 800 & $\begin{array}{l}168.5 \\
533 \\
671.5 \\
503 \\
139.5\end{array}$ & $\begin{array}{l}0.67 \\
0.80 \\
0.61 \\
0.35 \\
2.56\end{array}$ & $\begin{array}{l}0.12 \\
0.16 \\
0.11 \\
0.06 \\
0.46\end{array}$ \\
\hline Incoloy 825 & $\begin{array}{l}168.5 \\
533 \\
671 \\
503 \\
139.5\end{array}$ & $\begin{array}{l}0.66 \\
0.46 \\
0.23 \\
0.35 \\
1.11\end{array}$ & $\begin{array}{l}0.12 \\
0.08 \\
0.04 \\
0.06 \\
0.20\end{array}$ \\
\hline Inconel 600 & $\begin{array}{l}165 \\
480 \\
667 \\
502 \\
192\end{array}$ & $\begin{array}{l}1.41 \\
0.39 \\
0.73 \\
0.69 \\
0.79\end{array}$ & $\begin{array}{l}0.24 \\
0.07 \\
0.12 \\
0.11 \\
0.31\end{array}$ \\
\hline Inconel 625 & $\begin{array}{l}165 \\
480 \\
667 \\
502 \\
192\end{array}$ & $\begin{array}{l}0.21 \\
0.19 \\
0.37 \\
0.29 \\
1.28\end{array}$ & $\begin{array}{l}0.04 \\
0.03 \\
0.06 \\
0.05 \\
0.22\end{array}$ \\
\hline \multicolumn{4}{|l|}{ Miscellaneous metals } \\
\hline Carbon steel & $\begin{array}{l}216 \\
216 \\
216\end{array}$ & $\begin{array}{l}1210.78 \\
1158.96 \\
1145.15\end{array}$ & $\begin{array}{l}221.33 \\
211.56 \\
209.33\end{array}$ \\
\hline High-silicon cast iron & $\begin{array}{l}168 \\
330 \\
512 \\
497.5 \\
153.5\end{array}$ & $\begin{array}{r}440.84 \\
443.00 \\
367.40 \\
631.43 \\
1576.83\end{array}$ & $\begin{array}{r}86.77 \\
87.19 \\
72.31 \\
124.27 \\
310.35\end{array}$ \\
\hline $9 \mathrm{Cr}-1 \mathrm{Mo}$ & $\begin{array}{l}169 \\
532.5 \\
672 \\
503 \\
139.5\end{array}$ & $\begin{array}{r}33.21 \\
19.46 \\
3.30 \\
3.30 \\
13.42\end{array}$ & $\begin{array}{l}6.04 \\
3.54 \\
0.60 \\
0.60 \\
2.44\end{array}$ \\
\hline
\end{tabular}


Table 5. (continued)

\begin{tabular}{|c|c|c|c|}
\hline \multirow[b]{2}{*}{ Meta 1} & \multirow[b]{2}{*}{$\begin{array}{l}\text { Time } \\
(\mathrm{hr})\end{array}$} & \multicolumn{2}{|c|}{ Corrosion } \\
\hline & & mdd & mpy \\
\hline \multicolumn{4}{|l|}{$\begin{array}{l}10,000 \mathrm{ppm} \text { chloride } \\
\text { (continued) }\end{array}$} \\
\hline \multicolumn{4}{|l|}{ Aluminum alloys } \\
\hline Aluminum 1100 & $\begin{array}{l}201 \\
491.5 \\
835 \\
614 \\
343.5\end{array}$ & $\begin{array}{r}48.71 \\
27.15 \\
26.04 \\
4.14 \\
2.64\end{array}$ & $\begin{array}{r}31.68 \\
17.65 \\
16.93 \\
2.69 \\
1.72\end{array}$ \\
\hline Aluminum 6061 & $\begin{array}{l}257.5 \\
596 \\
789 \\
525.5 \\
193\end{array}$ & $\begin{array}{r}84.44 \\
38.48 \\
30.52 \\
1.68 \\
9.93\end{array}$ & $\begin{array}{r}44.94 \\
20.48 \\
16.24 \\
0.89 \\
5.39\end{array}$ \\
\hline \multicolumn{4}{|l|}{ Pure metals } \\
\hline Copper & $\begin{array}{l}164 \\
333 \\
500 \\
167\end{array}$ & $\begin{array}{l}3.33 \\
2.61 \\
1.80 \\
4.07\end{array}$ & $\begin{array}{l}0.54 \\
0.42 \\
0.29 \\
0.66\end{array}$ \\
\hline Nickel 200 & $\begin{array}{l}143 \\
336 \\
578.5 \\
210.5\end{array}$ & $\begin{array}{l}1.17 \\
0.25 \\
0.60 \\
1.55\end{array}$ & $\begin{array}{l}0.19 \\
0.04 \\
0.10 \\
0.25\end{array}$ \\
\hline Zirconium & $\begin{array}{l}256 \\
619 \\
766 \\
509 \\
147\end{array}$ & $\begin{array}{r}22.72 \\
5.74 \\
5.07 \\
6.79 \\
0.45\end{array}$ & $\begin{array}{l}3.20 \\
1.27 \\
1.12 \\
1.50 \\
0.10\end{array}$ \\
\hline Molybdenum & $\begin{array}{l}257 \\
619 \\
766 \\
509 \\
147\end{array}$ & $\begin{array}{l}22.72 \\
28.54 \\
30.88 \\
11.23 \\
10.73\end{array}$ & $\begin{array}{l}3.20 \\
4.02 \\
4.35 \\
1.59 \\
1.53\end{array}$ \\
\hline Titanium & $\begin{array}{l}175 \\
480 \\
667 \\
502 \\
192\end{array}$ & $\begin{array}{l}0.27 \\
0.07 \\
0.30 \\
0.42 \\
0.93\end{array}$ & $\begin{array}{l}0.09 \\
0.02 \\
0.10 \\
0.13 \\
0.30\end{array}$ \\
\hline
\end{tabular}


Table 5. (continued)

\begin{tabular}{|c|c|c|c|}
\hline \multirow[b]{2}{*}{ Metal } & \multirow{2}{*}{$\begin{array}{l}\text { Time } \\
(\mathrm{hr})\end{array}$} & \multicolumn{2}{|c|}{ Corrosion } \\
\hline & & mdd & mpy \\
\hline \multicolumn{4}{|l|}{$\begin{array}{l}10,000 \mathrm{ppm} \text { chloride } \\
\text { (continued) }\end{array}$} \\
\hline \multicolumn{4}{|c|}{ Pure metals (continued) } \\
\hline Zinc & $\begin{array}{l}186 \\
528 \\
777 \\
136\end{array}$ & $\begin{array}{l}41.35 \\
15.73 \\
12.30 \\
27.33\end{array}$ & $\begin{array}{l}8.32 \\
3.17 \\
2.47 \\
5.50\end{array}$ \\
\hline \multicolumn{4}{|l|}{$50,000 \mathrm{ppm}$ chloride } \\
\hline \multicolumn{4}{|c|}{ Copper-nickel alloys } \\
\hline \multirow[t]{5}{*}{$90 / 10$} & 167 & 74.04 & 12.38 \\
\hline & 502 & 32.33 & 5.20 \\
\hline & 648 & 25.55 & 4.11 \\
\hline & 479 & 16.14 & 2.59 \\
\hline & 144 & 76.74 & 12.33 \\
\hline \multirow[t]{5}{*}{ Monel 400} & 190 & 4.76 & 0.77 \\
\hline & 473.5 & 9.48 & 0.31 \\
\hline & 652 & 2.10 & 0.34 \\
\hline & 462 & 1.48 & 0.24 \\
\hline & 178.5 & 3.03 & 0.49 \\
\hline \multirow[t]{5}{*}{$70 / 30$} & 186 & 11.08 & 1.78 \\
\hline & 528 & 6.10 & 0.98 \\
\hline & 777 & 4.75 & 0.76 \\
\hline & 481 & 29.84 & 3.26 \\
\hline & 161 & 38.75 & 6.23 \\
\hline \multicolumn{4}{|l|}{ Copper-zinc alloys } \\
\hline \multirow[t]{5}{*}{ Red brass } & 165 & 19.06 & 3.13 \\
\hline & 520 & 8.34 & 1.37 \\
\hline & 737 & 6.27 & 1.03 \\
\hline & 524 & 3.71 & 0.61 \\
\hline & 169 & 10.78 & 1.77 \\
\hline \multirow[t]{5}{*}{ Admiralty brass } & 165 & 9.91 & 1.67 \\
\hline & 520 & 11.57 & 1.95 \\
\hline & 737 & 8.67 & 1.46 \\
\hline & 524 & 10.69 & 1.80 \\
\hline & 169 & 18.11 & 3.05 \\
\hline
\end{tabular}


Table 5. (continued)

\begin{tabular}{|c|c|c|c|}
\hline \multirow[b]{2}{*}{ Metal } & \multirow{2}{*}{$\begin{array}{l}\text { Time } \\
(\mathrm{hr})\end{array}$} & \multicolumn{2}{|c|}{ Corrosion } \\
\hline & & mdd & mpy \\
\hline \multicolumn{4}{|l|}{$\begin{array}{l}50,000 \mathrm{ppm} \text { chloride } \\
\text { (continued) }\end{array}$} \\
\hline \multicolumn{4}{|l|}{$\begin{array}{l}\text { Copper-zinc alloys } \\
\text { (continued) }\end{array}$} \\
\hline \multirow{5}{*}{ Yellow brass } & 190 & 14.94 & 2.54 \\
\hline & 473.5 & 14.81 & 2.51 \\
\hline & 652 & 10.94 & 1.86 \\
\hline & 462 & 36.67 & 6.22 \\
\hline & 168.5 & 57.72 & 9.79 \\
\hline \multicolumn{4}{|l|}{ Bronzes } \\
\hline \multirow[t]{5}{*}{ AmpCo $8 \mathrm{~F}$} & 451 & 14.067 & 2.44 \\
\hline & 1222.5 & 5.49 & 0.95 \\
\hline & 1687.5 & 4.79 & 0.83 \\
\hline & 1043.5 & 3.12 & 0.54 \\
\hline & 178.5 & 31.05 & 5.37 \\
\hline \multirow[t]{5}{*}{ AmpCo 483P } & 147 & 25.52 & 4.42 \\
\hline & 508 & 12.83 & 2.22 \\
\hline & 644 & 24.84 & 4.30 \\
\hline & 496 & 4.68 & 0.81 \\
\hline & 136 & 30.63 & 5.30 \\
\hline \multirow[t]{5}{*}{ AmpCo $12 \mathrm{SF}$} & 147 & 5.74 & 0.99 \\
\hline & 508 & 1.78 & 0.31 \\
\hline & 644 & 1.73 & 0.30 \\
\hline & 496 & 1.67 & 0.29 \\
\hline & 136 & 4.20 & 0.73 \\
\hline \multirow[t]{5}{*}{ Phosphorus bronze } & 190 & 5.49 & 0.90 \\
\hline & 473.5 & 4.64 & 0.76 \\
\hline & 652 & 4.73 & 0.77 \\
\hline & 462 & 2.84 & 0.47 \\
\hline & 178.5 & 7.64 & 1.25 \\
\hline \multicolumn{4}{|l|}{ Austenitic stainless steels } \\
\hline \multirow[t]{5}{*}{ Allegheny $6 \mathrm{X}$} & 240 & 0.88 & 0.19 \\
\hline & 504 & 0.44 & 0.10 \\
\hline & 648 & 0.38 & 0.08 \\
\hline & 408 & 0.55 & 0.12 \\
\hline & 144 & 1.39 & 0.31 \\
\hline
\end{tabular}


Table 5. (continued)

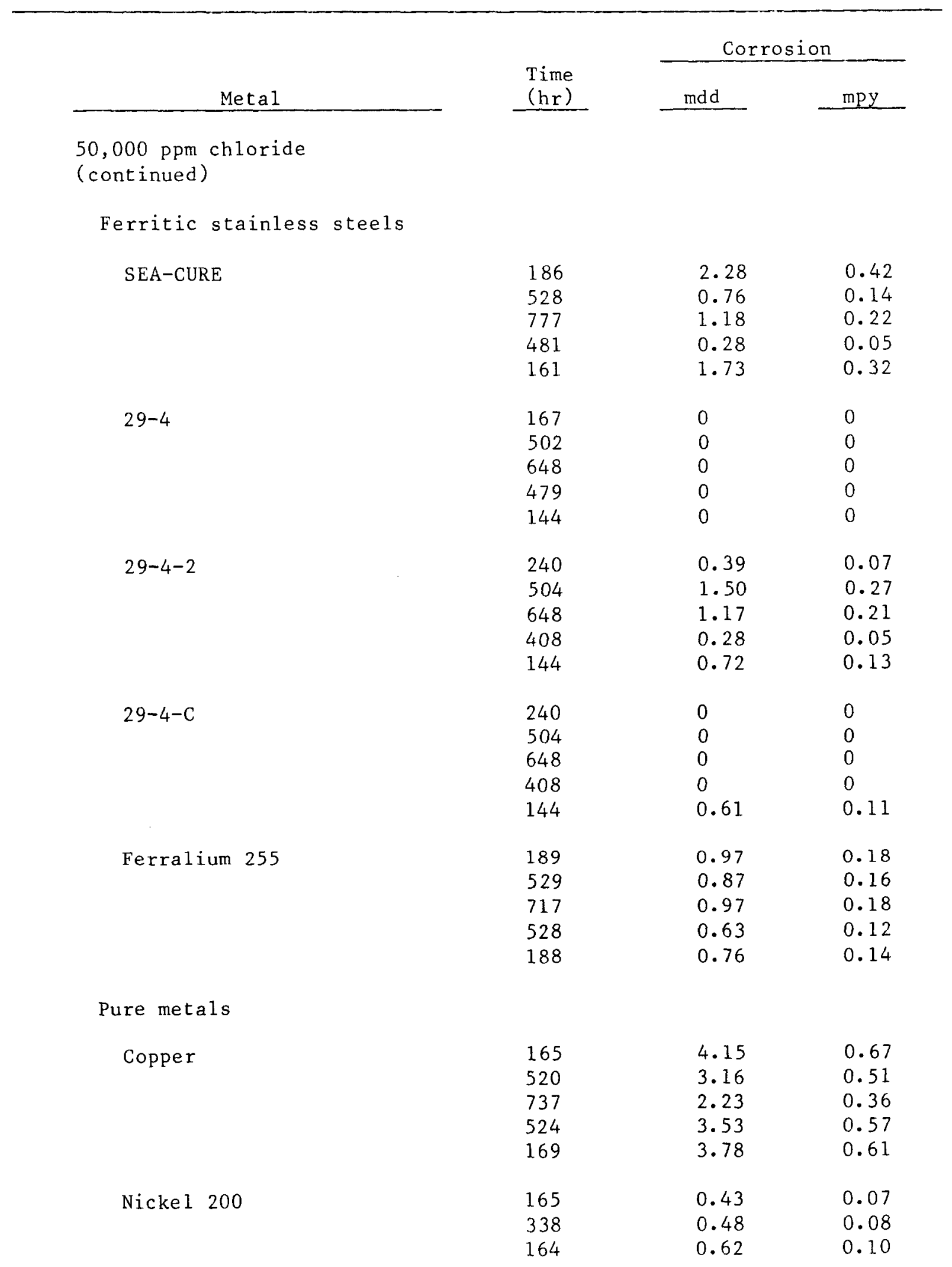


Table 5. (continued)

\begin{tabular}{|c|c|c|c|}
\hline \multirow[b]{2}{*}{ Metal } & \multirow[b]{2}{*}{$\begin{array}{l}\text { Time } \\
(\mathrm{hr}) \\
\end{array}$} & \multicolumn{2}{|c|}{ Corrosion } \\
\hline & & mdd & mpy \\
\hline \multicolumn{4}{|l|}{$\begin{array}{l}50,000 \mathrm{ppm} \text { chloride } \\
\text { (continued) }\end{array}$} \\
\hline \multicolumn{4}{|c|}{ Pure metals (continued) } \\
\hline Titanium & $\begin{array}{l}165 \\
520 \\
737 \\
524 \\
169\end{array}$ & $\begin{array}{l}2.22 \\
0.46 \\
0.46 \\
0.36 \\
1.72\end{array}$ & $\begin{array}{l}0.71 \\
0.15 \\
0.15 \\
0.12 \\
0.55\end{array}$ \\
\hline \multicolumn{4}{|l|}{100,000 ppm chloride } \\
\hline \multicolumn{4}{|l|}{ Copper-nickel alloys } \\
\hline $90 / 10$ & 227 & 71.73 & 11.53 \\
\hline $70 / 30$ & $\begin{array}{l}146 \\
503 \\
695 \\
551 \\
192\end{array}$ & $\begin{array}{r}53.63 \\
16.24 \\
11.88 \\
0.05 \\
24.46\end{array}$ & $\begin{array}{l}8.62 \\
2.61 \\
1.91 \\
0.80 \\
3.90\end{array}$ \\
\hline Mone 1400 & $\begin{array}{l}146 \\
503 \\
695 \\
551 \\
192\end{array}$ & $\begin{array}{l}9.34 \\
2.99 \\
2.72 \\
2.84 \\
7.25\end{array}$ & $\begin{array}{l}1.51 \\
0.48 \\
0.44 \\
0.46 \\
1.17\end{array}$ \\
\hline \multicolumn{4}{|l|}{ Copper-zinc alloys } \\
\hline Red brass & 227 & 222.9 & 36.6 \\
\hline Admiralty brass & 227 & 100.9 & 17.0 \\
\hline Yellow brass & 227 & 117.3 & 19.9 \\
\hline \multicolumn{4}{|l|}{ Bronzes } \\
\hline Phosphorus bronze & 189 & 36.96 & 6.05 \\
\hline \multicolumn{4}{|c|}{ Austenitic stainless steels } \\
\hline Allegheny $6 \mathrm{X}$ & $\begin{array}{l}146 \\
503 \\
695 \\
551 \\
192\end{array}$ & $\begin{array}{l}0 \\
0 \\
0 \\
0 \\
0\end{array}$ & $\begin{array}{l}0 \\
0 \\
0 \\
0 \\
0\end{array}$ \\
\hline
\end{tabular}


Table 5. (continued)

\begin{tabular}{|c|c|c|c|}
\hline \multirow[b]{2}{*}{ Meta1 } & \multirow{2}{*}{$\begin{array}{l}\text { Time } \\
(\mathrm{hr})\end{array}$} & \multicolumn{2}{|c|}{ Corrosion } \\
\hline & & mdd & mpy \\
\hline \multicolumn{4}{|l|}{$\begin{array}{l}100,000 \mathrm{ppm} \text { chloride } \\
\text { (continued) }\end{array}$} \\
\hline \multicolumn{4}{|l|}{ Ferritic stainless steels } \\
\hline SEA-CURE & $\begin{array}{l}201 \\
491.5 \\
835 \\
614 \\
343.5\end{array}$ & $\begin{array}{l}0 \\
0 \\
0.05 \\
0.38 \\
0.01\end{array}$ & $\begin{array}{l}0 \\
0 \\
0.01 \\
0.02 \\
0.006\end{array}$ \\
\hline $29-4$ & $\begin{array}{l}163 \\
337 \\
164\end{array}$ & $\begin{array}{l}8.17 \\
2.02 \\
6.62\end{array}$ & $\begin{array}{l}1.49 \\
0.37 \\
1.21\end{array}$ \\
\hline $29-4-2$ & $\begin{array}{l}146 \\
503 \\
695 \\
551 \\
192\end{array}$ & $\begin{array}{l}0 \\
0 \\
0 \\
0 \\
0\end{array}$ & $\begin{array}{l}0 \\
0 \\
0 \\
0 \\
0\end{array}$ \\
\hline $29-4-C$ & $\begin{array}{l}146 \\
503 \\
695 \\
551 \\
192\end{array}$ & $\begin{array}{l}0 \\
0 \\
0 \\
0 \\
0\end{array}$ & $\begin{array}{l}0 \\
0 \\
0 \\
0 \\
0\end{array}$ \\
\hline Ferralium 255 & $\begin{array}{l}189 \\
529 \\
717 \\
528 \\
188\end{array}$ & $\begin{array}{l}0.05 \\
0.43 \\
1.25 \\
0.33 \\
0.41\end{array}$ & $\begin{array}{l}0.01 \\
0.08 \\
0.23 \\
0.06 \\
0.08\end{array}$ \\
\hline \multicolumn{4}{|l|}{ Pure metals } \\
\hline Pure copper & 189 & 120.38 & 19.41 \\
\hline Nickel 200 & $\begin{array}{l}189 \\
529 \\
717 \\
528 \\
188\end{array}$ & $\begin{array}{l}0.87 \\
0.99 \\
0.93 \\
0.80 \\
1.36\end{array}$ & $\begin{array}{l}0.14 \\
0.16 \\
0.15 \\
0.13 \\
0.22\end{array}$ \\
\hline
\end{tabular}


Table 5. (continued

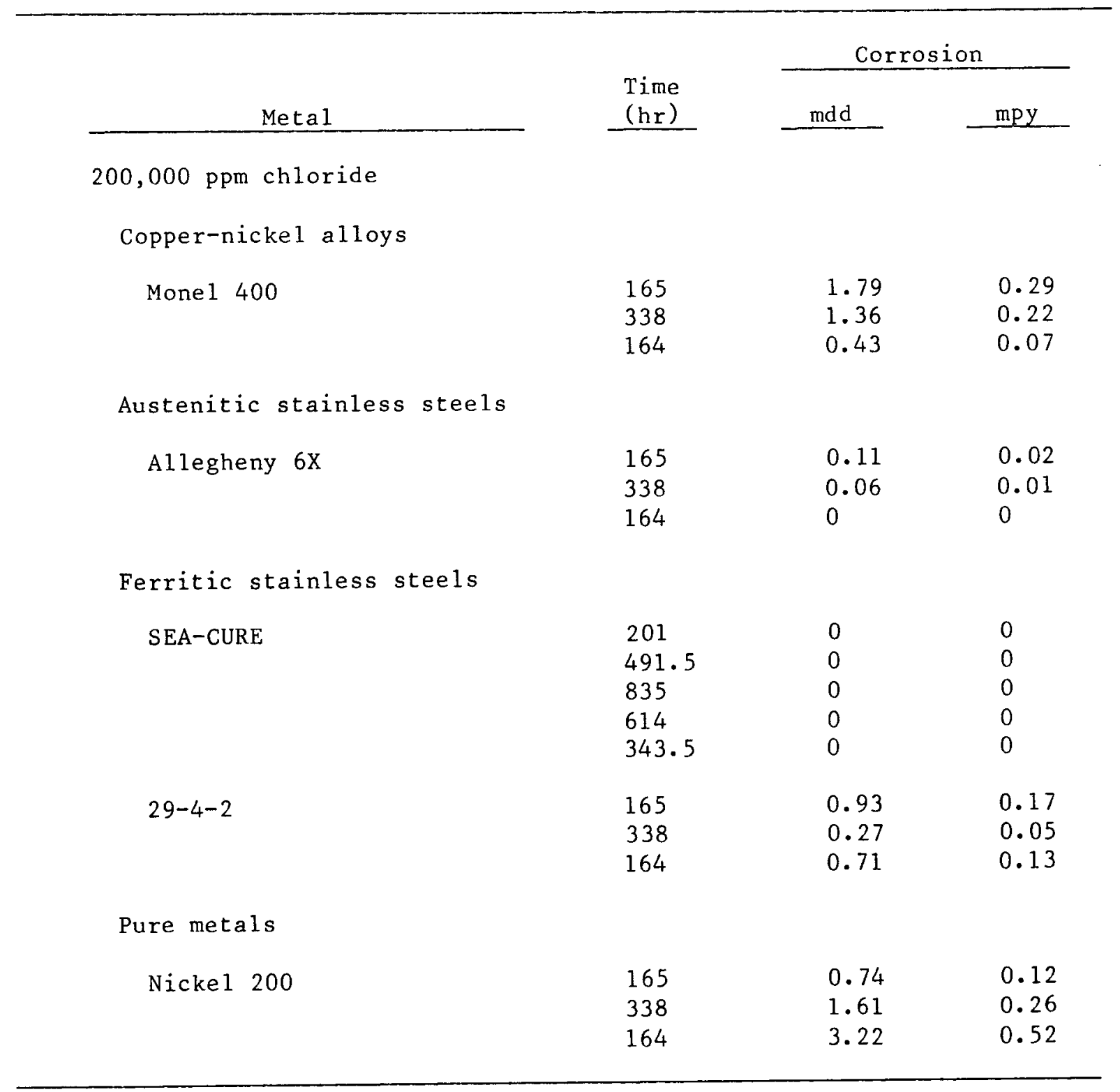


Table 6. Results of the pilot cooling tower tests

\begin{tabular}{|c|c|c|c|c|}
\hline \multirow[b]{2}{*}{ Alloy } & \multirow{2}{*}{$\begin{array}{l}\text { Duration } \\
\text { (months) }\end{array}$} & \multicolumn{2}{|c|}{ Corrosion Rate } & \multirow[b]{2}{*}{ Comments } \\
\hline & & mdd & mpy & \\
\hline SEA-CURE & 10 & 0.93 & 0.17 & No pitting or crevice corrosion \\
\hline $70 / 30$ & 10 & 1.18 & 0.19 & No pitting or crevice corrosion \\
\hline $90 / 10$ & 4 & 1.87 & 0.30 & Dealloying and pitting \\
\hline Admiralty & 6 & 1.48 & 0.25 & Dealloying \\
\hline Carbon steel & 4 & 21.72 & 4.0 & Crevice and pitting corrosion \\
\hline $12 \mathrm{Cr}$ & 6 & 9.57 & 1.76 & Crevice and pitting corrosion \\
\hline Allegheny $6 \mathrm{X}$ & 4 & 3.39 & 0.60 & Pitting corrosion \\
\hline $29-4-C$ & 4 & 1.59 & 0.29 & No pitting or crevice corrosion \\
\hline Mone1 400 & 4 & 3.88 & 0.63 & Pitting corrosion \\
\hline Aluminum brass & 4 & 6.39 & 1.08 & Severe general corrosion \\
\hline Ferralium 255 & 2 & 2.66 & 0.49 & No pitting or crevice corrosion \\
\hline
\end{tabular}




\section{CONCLUSIONS AND RECOMMENDATIONS}

For some of the alloys, the corrosion rate increased as the chloride concentration was increased. These alloys included 70/30, Monel 400, Admiralty Brass, Red Brass, and Yellow Brass. For the remaining alloys, the corrosion rate decreased with the increase in chloride concentration. These included 90/10, SEA-CURE, Allegheny 6X, 29-4-2, 29-4-C, and Nickel 200. The decrease in corrosion rate with increased chloride concentration is probably due to the decrease in dissolved oxygen at the higher chloride level. Table 7 shows the decrease in dissolved oxygen for increased chloride for an alloy showing little general corrosion.

Figure $23^{3}$ and Table $8^{4}$ show the corrosion rates of several metals exposed to seawater and to salted geothermal brine. Exposure times and chloride concentrations are different, making a direct comparison impossible. The differences in corrosion rate, however, indicate a unique difference between geothermal water and seawater. These differences are probably due to different trace elements in the two.

Figures 24 and 25 show the general trend of corrosion rate as a function of chloride concentration for the alloys named at the beginning of this section. The data show that several materials exhibiting excellent corrosion resistance are available for condenser tubing and other cooling water system components.
The recommended materials and their use are summarized below:

- Ferritic stainless steels should be used for condenser tubing. A linear extrapolation of the corrosion data gives an expected life of 47 to 70 years.

- The copper-nickel alloys can be used as condenser tubing material in high-salinity water. Their use, however, may require the use of a copper inhibitor. A linear extrapolation of the corrosion data for these alloys gives an expected life of 22 to 40 years.

- Although several austenitic stainless steels and nickel-based alloys exhibited good corrosion resistance, preliminary cost comparisons indicate that these metals are more expensive than the ferritic materials.

- Carbon steel is adequate for shell material if those portions exposed to the brine (water boxes) are organically coated or clad with a corrosion-resistant material.

- Carbon steel piping should be coated or else replaced with plastic pipe.

It is further recommended that corrosion tests be performed at other sites to verify that the data have generic application to geothermal areas. 


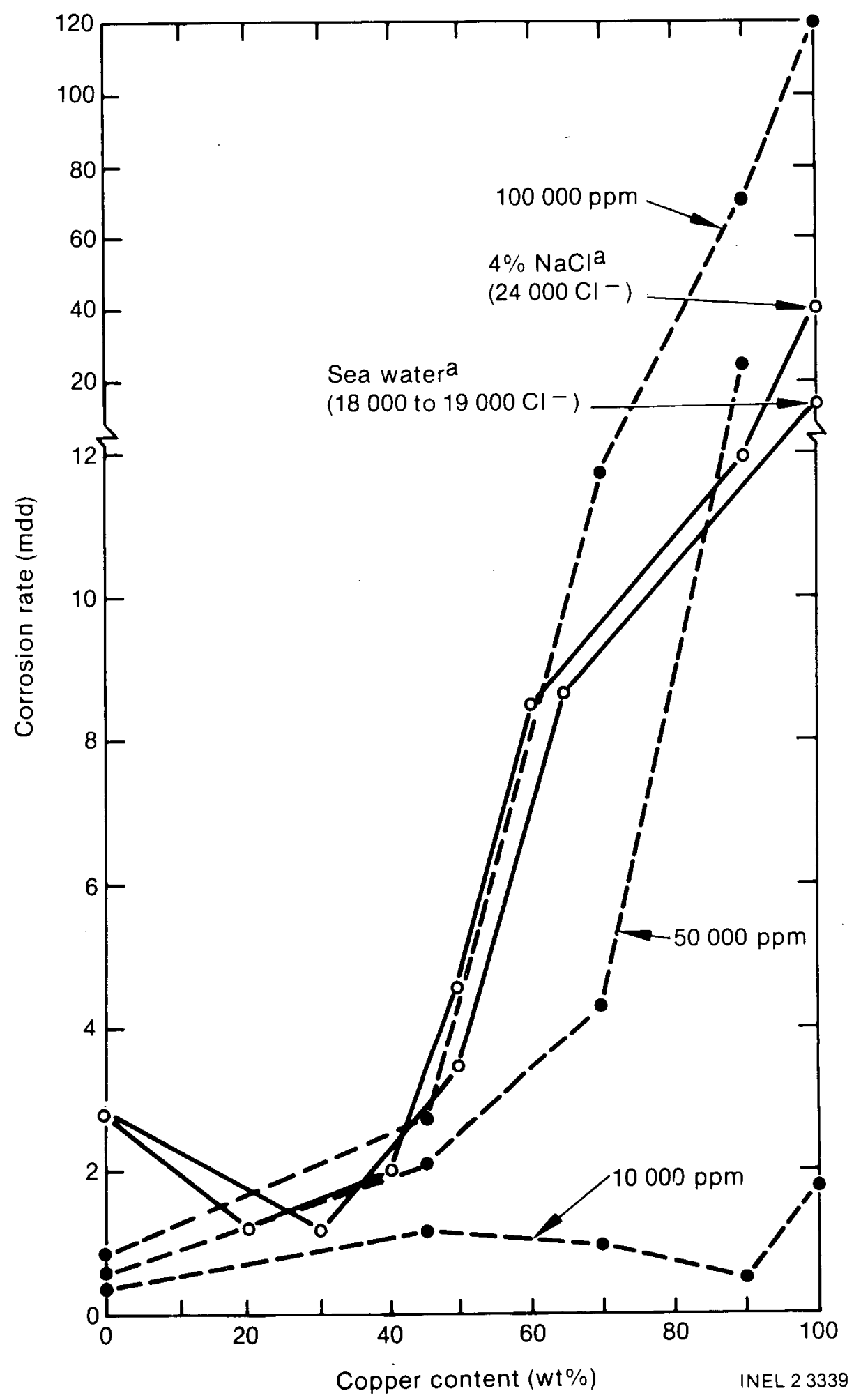

a. Data from Wayne Z. Friend, Corrosion of Nickel and Nickel-Base Alloys, 1980, John Wiley \& Sons Inc., New York.

Figure 23. Corrosion as a function of copper content. 


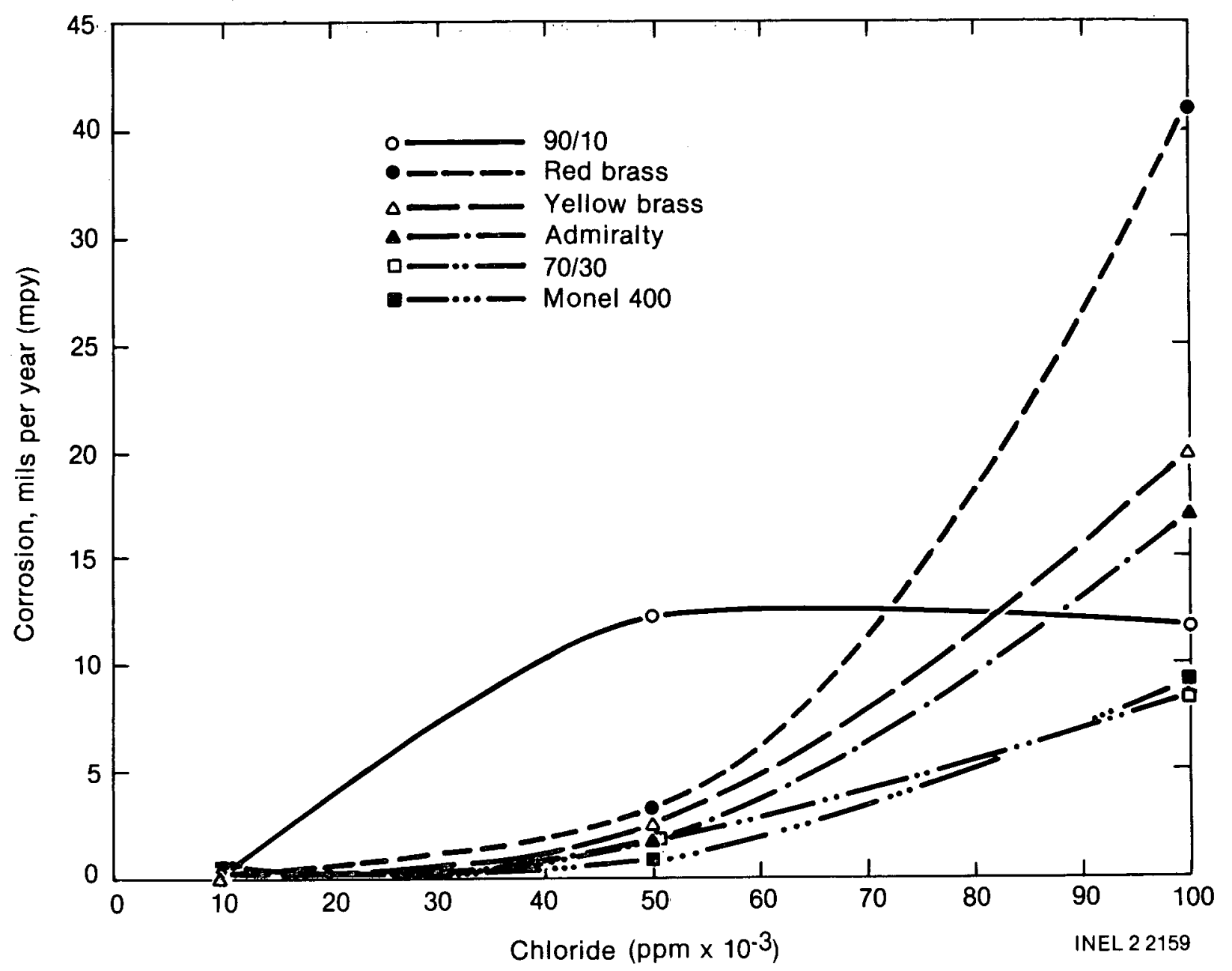

Figure 24. Corrosion as a function of chloride concentration level. 


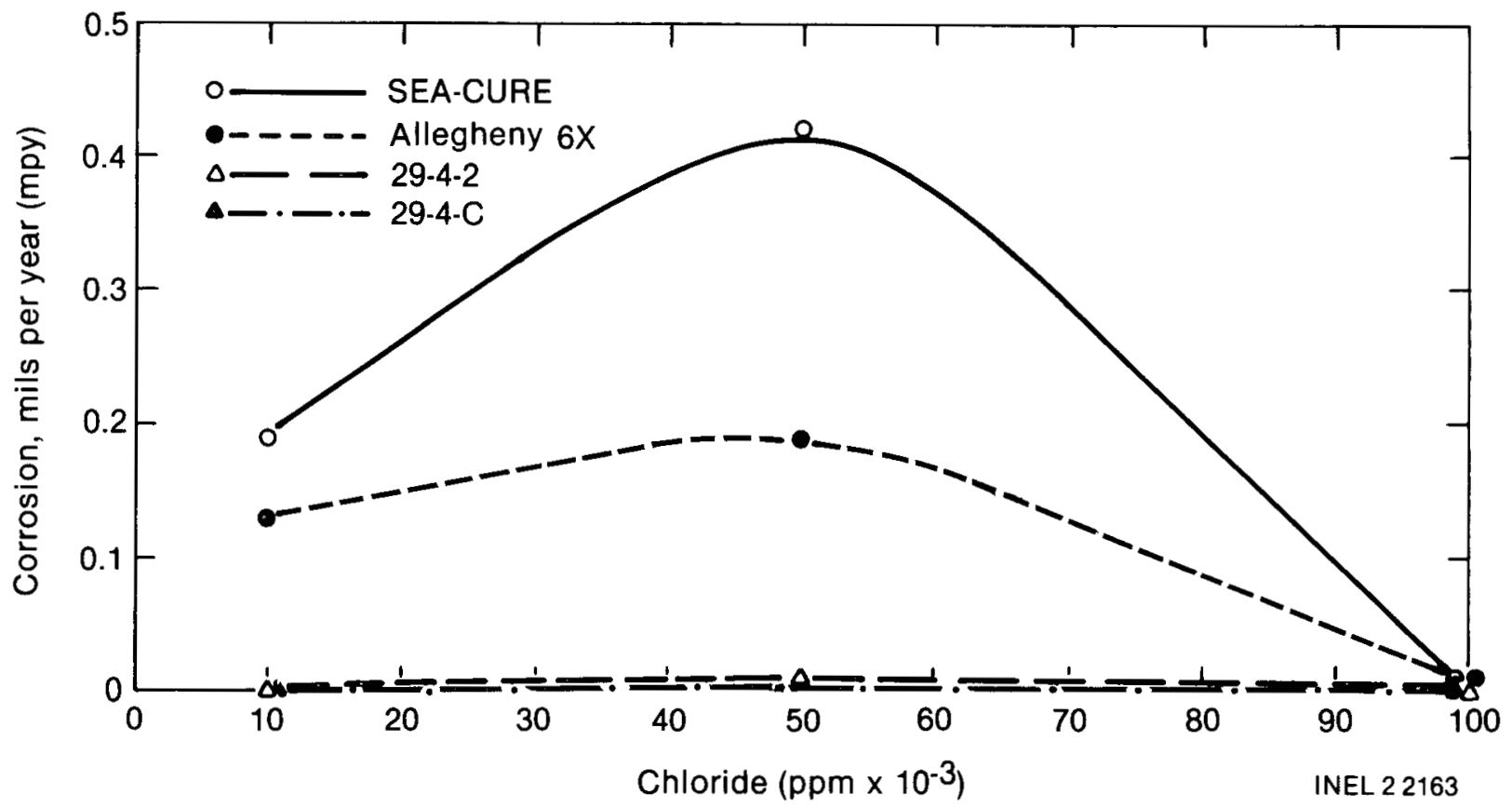

Figure 25. Corrosion as a function of chloride concentration level.

Table 7. Dissolved oxygen as a function of chloride concentration

\begin{tabular}{cc}
$\begin{array}{c}\text { Chloride } \\
(\mathrm{ppm})\end{array}$ & $\begin{array}{c}\text { Dissolved Oxygen } \\
{[\mathrm{ppm}(\mathrm{mg} / \mathrm{L})]}\end{array}$ \\
\hline & \\
10,000 & 6.8 \\
50,000 & 5.4 \\
100,000 & 4.8 \\
200,000 & 4.7
\end{tabular}


Table 8. Comparison of corrosion rates of materials exposed to geothermal brine and to seawater

\begin{tabular}{|c|c|c|c|c|c|c|c|c|}
\hline \multirow[b]{4}{*}{ Meta 1} & \multicolumn{8}{|c|}{ Corrosion } \\
\hline & \multirow{2}{*}{\multicolumn{2}{|c|}{ SeaWater }} & \multicolumn{6}{|c|}{ Chloride ${ }^{a}$} \\
\hline & & & \multicolumn{2}{|c|}{$10,000 \mathrm{mg} / \mathrm{L}$} & \multicolumn{2}{|c|}{$50,000 \mathrm{mg} / \mathrm{L}$} & \multicolumn{2}{|c|}{$100,000 \mathrm{mg} / \mathrm{L}$} \\
\hline & mdd & mpy & mdd & mpy & $\underline{\mathrm{mdd}}$ & mpy & mdd & mpy \\
\hline 316 stainless steel & 0.6 & $0.1^{b}$ & 0.28 & 0.05 & -- & -- & $--:$ & -- \\
\hline 304 stainless steel & 2.2 & $0.4^{c}$ & 0.05 & 0.01 & -- & -- & -- & -- \\
\hline Copper & 9.9 & $1.6^{\mathrm{d}}$ & 1.80 & 0.29 & 2.24 & 0.36 & 120.79 & 19.41 \\
\hline $70 / 30$ copper nickel & 1.9 & $0.3^{\mathrm{d}}$ & 0.93 & 0.15 & 4.73 & 0.76 & 11.88 & 1.91 \\
\hline Admiralty brass & 10.7 & $1.8^{\mathrm{d}}$ & 1.66 & 0.28 & 8.67 & 1.46 & 100.93 & 17.0 \\
\hline Aluminum brass & 4.73 & $0.8^{\mathrm{d}}$ & 6.39 & 1.08 & -- & -- & -- & -- \\
\hline Naval brass & 10.0 & $1.7^{\mathrm{d}}$ & 6.91 & 1.18 & -- & -- & -- & -- \\
\hline Red brass & 11.0 & $1.8^{\mathrm{d}}$ & 1.34 & 0.22 & 6.27 & 1.03 & 222.89 & 36.60 \\
\hline Aluminum bronze & 10.4 & $1.9^{d}$ & 128.83 & 23.46 & -- & -- & -- & -- \\
\hline Silicon bronze & 10.1 & $1.7^{\mathrm{d}}$ & 149.02 & 25.10 & -- & -- & -- & -- \\
\hline Muntz metal & 13.0 & $2 \cdot 2^{\mathrm{d}}$ & 10.38 & 1.76 & -- & -- & -- & -- \\
\hline
\end{tabular}

a. The data for the different levels of chloride are from the 30-day spinner tests, with the exception of those for aluminum brass, which are from the cooling tower tests.

b. The test duration was 1645 days. Data are from the Meta1s Handbook, Properties and Selection of Metals, Vol. 1, 8th ed., 1975, American Society for Metals, Metals Park, Ohio.

c. The test duration was 6 months; the data source is the same as for "a."

d. The test duration was 1 year; the data source is the same as for "a." 


\section{REFERENCES}

1. A. Wachter, R. S. Treseder, "Corrosion Testing Evaluation of Metals for Process Equipment," Chemical Engineering Progress, 43, 1947, pp. 315-326.

2. Standard Methods of Test for Corrosivity of Water in the Absence of Heat Transfer (Weight Loss Methods), ASTM Designation: D2688-70.

3. Metals Handbook, Properties and Selection of Materials, Vol. 1, 8th Ed., Metals Park, Ohio: American Society for Metals, 1975.

4. Wayne Z. Friend, Corrosion of Nickel and Nickel-Base Alloys, New York: John Wiley \& Sons, 1980. 


\section{BIBLIOGRAPHY}

D. B. Anderson and K. D. Efiro, "Cu-Ni Resists Recirculated Sea Water," reprinted from Power, February 1974.

A. I. Asphahani, P. E. Manning, W. L. Silence, F. G. Hodge, "Highly Alloyed Stainless Materials for Seawater Applications," Paper Number 29, Corrosion/80.

A. P. Bond, C. Bertoli, H. J. Dundas, "Corrosion Resistance of Stainless Steels in Seawater," Proceedings of the Symposium, Placenza, Italy, February 28, 1980.

The International Nickel Company, Inc., Corrosion Resistance of Wrought 90/10 Copper-Nickel-Iron Alloy in Marine Environments, Marine Corrosion Bulletin MCB-1.

"Corrosion and the Process Plant," reprinted from Chemical Engineering, McGraw-Hill Inc., New York, $1971,1972$.

Wayne Z. Friend, Corrosion of Nickel and Nickel-Base Alloys, New York: John Wiley \& Sons, 1980.

F. Galen Hodge, Corrosion Resistance of Ferralium Alloy 255, Cabot Corporation, Kokomo, Indiana.

M. J. Johnson, I. A. Franson, "Corrosion of Stainless Steel in Saturated NaCl Brine Solutions," Paper Number 93, Corrosion/80.

Gary N. Kirby, "How to Select Materials," Chemical Engineering, November 3, 1980, pp. 86-146.

C. W. Kovach, L. S. Redmerski, H. D. Kurtz, Crevice Corrosion Performance of a Ferritic Stainless Steel Designed for Saline Water Condenser and Heat Exchanger Applications, Colt Industries.

Light-Wall Copper-Nickel Condenser Tube, Copper Development Association Inc., New York, August 1973.

T. P. May, B. A. Weldon, Copper-Nickel Alloys for Service in Seawater, Travaux du Centre de Recherches et d'Etudes Oceanographiques, 1965, 6(1-2-3-4), pp. 141-156.

Metals Handbook, Properties and Selection of Materials, Vol. 1, 8th Ed., Metals Park, Ohio: American Society for Metals, 1975.

G. E. Moller, "The Successful Use of Austenitic Stainless Steels in Seawater," reprinted from Society of Petroleum Engineers Journal, April, 1977.

T. J. Nichol, I. A. Franson, G. E. Moller, "Applications of New High-Chromium Ferritic Stainless Steels in the Chemical Process Industries," Corrosion/81.

Standard Methods of Test for Corrosivity of Water in the Absence of Heat Transfer (Weight Loss Methods), ASTM Designation: D2688-70.

"Small-Scale Short-Term Methods of Evaluating Cooling Water Treatments-Are They Worth While?" International Water Conference, Pittsburg, Pennsylvania, November 4-6, 1976.

C. M. Schillmoller, H. P. Klein, “Applications for High Technology Stainless Steels,” National Association of Corrosion Engineers, Canadian Region, Western Division Meeting, Edmonton, Alberta, February 14, 1980.

Michael A. Streicher, "Stainless Steels: Past, Present, and Future," Stainless Steel '77.

A. Wachter, R. S. Treseder, "Corrosion Testing Evaluation of Metals for Process Equipment," Chemical Engineering Progress, 43, 1947. 